\title{
Marianna Matrone
}

Avaliação de diferentes protocolos de extração de DNA para detecção de Brucella abortus a partir de materiais colhidos de feto abortado ou bezerros nascidos de vacas experimentalmente infectadas com a cepa 2308 


\title{
MARIANNA MATRONE
}

\begin{abstract}
Avaliação de diferentes protocolos de extração de DNA para detecção de Brucella abortus a partir de materiais colhidos de feto abortado ou bezerros nascidos de vacas experimentalmente infectadas com cepa 2308
\end{abstract}

Dissertação apresentada ao Programa de PósGraduação em Epidemiologia Experimental Aplicada às Zoonoses da Faculdade de Medicina Veterinária e Zootecnia da Universidade de São Paulo para obtenção do título de Mestre em Medicina Veterinária

Departamento:

Medicina Veterinária Preventiva e Saúde Animal

Área de concentração:

Epidemiologia Experimental e Aplicada às Zoonoses

Orientador:

Prof. Dr. José Soares Ferreira Neto

São Paulo

2008 
Autorizo a reprodução parcial ou total desta obra, para fins acadêmicos, desde que citada a fonte.

DADOS INTERNACIONAIS DE CATALOGAÇÃO-NA-PUBLICAÇÃO

(Biblioteca Virginie Buff D’Ápice da Faculdade de Medicina Veterinária e Zootecnia da Universidade de São Paulo)

T.1978

Matrone, Marianna

Avaliação de diferentes protocolos de extração de DNA para detecção de Brucella abortus a partir de materiais colhidos de feto abortado ou bezerros nascidos de vacas experimentalmente infectadas com cepa 2308 / Marianna Matrone. - São Paulo : M. Matrone, 2008. $92 \mathrm{f}$ : : il.

Dissertação (mestrado) - Universidade de São Paulo. Faculdade de Medicina Veterinária e Zootecnia. Departamento de Medicina Veterinária Preventiva e Saúde Animal, 2008.

Programa de Pós-Graduação: Epidemiologia Experimental e Aplicada às Zoonoses.

Área de concentração: Epidemiologia Experimental e Aplicada às Zoonoses.

Orientador: Prof. Dr. José Soares Ferreira Neto.

1. Bovinos. 2. Brucelose animal. 3. Reação em Cadeia pela Polimerase. 4. Bezerros. 5. Brucella abortus. I. Título. 


\section{UNIVERSIDADE DE SÃO PAULO Faculdade de Medicina Veterinária e Zootecnia}

Comissão Bioética

\section{CERTIFICADO}

Certificamos que o Projeto intitulado "Avaliação de diferentes protocolos de extração de DNA para deteç̧ão de Brucella abortus a partir de materiais colhidos de feto abortado ou bezerros nascidos de vacas experimentalmente infectadas com cepa 2308", protocolado sob o n¹133/2007, utilizando amostras de fetos abortados e bezerros previamente sacrificados, sob a responsabilidade do Prof. Dr. José Soares Ferreira Neto, está de acordo com os princípios éticos de experimentação animal da Comissão de Bioética da Faculdade de Medicina Veterinária e Zootecnia da Universidade de São Paulo e foi aprovado em reunião de 19/09/07.

We certify that the Research "Evaluation of different protocols of DNA extraction for Brucella abortus detection from aborted featus materials or from calves born from experimentally infected cows with 2308 strain", protocol number 1133/2007, under the responsibility Prof. Dr. José Soares Ferreira Neto, agree with Ethical Principles in Animal Research adopted by Bioethic Commission of the School of Veterinary Medicine and Animal Science of University of São Paulo and was approved in the meeting of day 09/19/07.

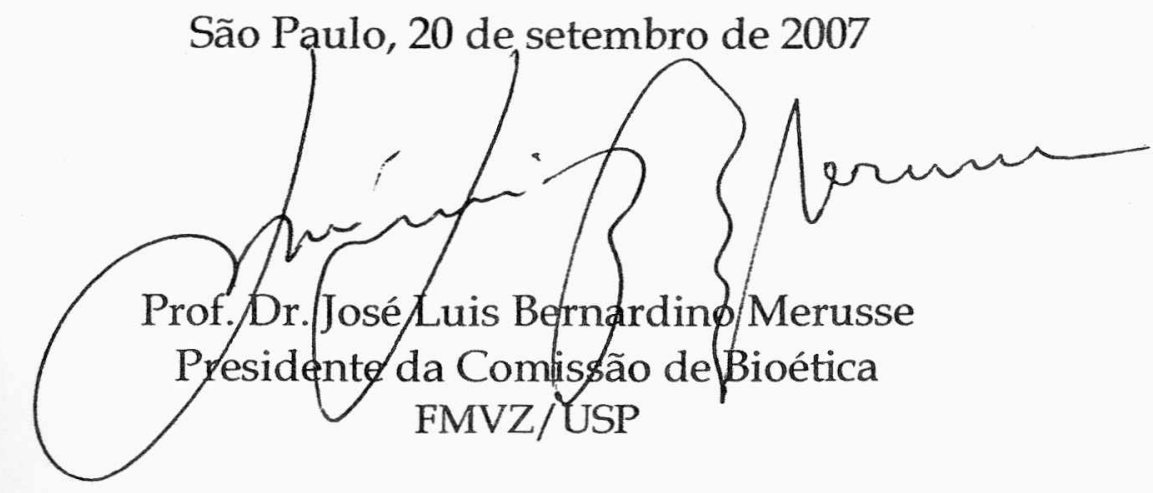

Av. Prof. Dr. Orlando Marques de Paiva, $n^{\circ} 87$ - 05508-270 - Cidade Universitária "Armando de Salles Oliveira". Fax: (11) 3032-2224 - fones: (11) 309107676/7671 - e-mail: fmvz@edu.usp.br 


\section{UNIVERSIDADE DE SÃO PAULO \\ Faculdade de Medicina Veterinária e Zootecnia \\ Cidade Universitária "Armando de Salles Oliveira" Comissão Bioética \\ CERTIFICADO}

Certificamos que o Projeto intitulado "Avaliação de vacina contra brucelose bovina não indutora de anticorpos (VNIA)" Protocolo $n^{\circ}$ 296/2003, utilizando 120 bovinos, sob a responsabilidade do Prof. Dr. José Soares Ferreira Neto, está de acordo com os princípios éticos de experimentação animal da Comissão de Bioética da Faculdade de Medicina Veterinária e Zootecnia da Universidade de São Paulo e foi aprovado "ad referendun".

(We certify that the Research "Evaluation of a new vaccine against bovine brucellosis" protocol number 296/2003, utilizing 120 bovines, under the responsibility of Prof. Dr. José Soares Ferreira Neto, agree with Ethical Principles in Animal Research adopted by Bioethic Commission of the Faculty of Veterinary Medicine and Zootechny of University of São Paulo and was approved "ad referendun").

São Paulo, 03 de abril de 2003

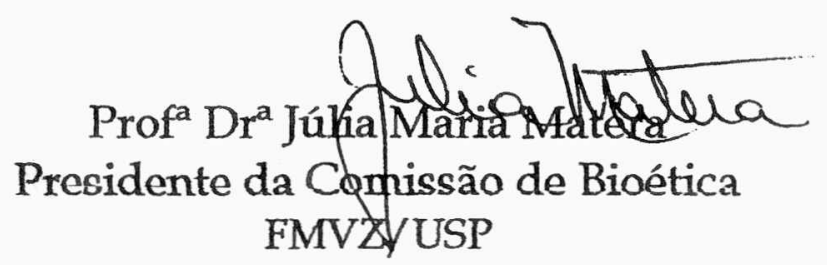




\section{FOLHA DE AVALIAÇÃO}

Nome: MATRONE, Marianna

Título: Avaliação de diferentes protocolos de extração de DNA para detecção de Brucella abortus a partir de materiais colhidos de feto abortado ou bezerros nascidos de vacas experimentalmente infectadas com cepa 2308

Data:

Dissertação apresentada ao Programa de PósGraduação em Epidemiologia Experimental e Aplicada às Zoonoses da Faculdade de Medicina Veterinária e Zootecnia da Universidade de São Paulo para obtenção do título de Mestre em Medicina Veterinária

Banca Examinadora

Prof. Dr:

Instituição:

Assinatura: Julgamento:

Prof. Dr: Instituição:

Assinatura: Julgamento:

Prof. Dr: Instituição:

Assinatura: Julgamento: 


\section{DEDICATÓRIAS}

Em primeiro lugar aos meus pais Julio e Marilurdes, pelo amor, confiança e ensinamentos em todos os dias de minha vida. A eles devo tudo o que sou e também o que um dia serei. Obrigado por existirem e por me mostrarem o caminho de Deus e da honestidade dos homens.

Aos meus irmãos Mauricio e Marcella, por todo amor, união, carinho e apoio, sempre presentes desde o inicio da minha existência. Amo vocês.

Aos meus cunhados Rui e Patrícia, pela amizade e carinho, sempre me apoiando e ajudando na realização de muitas conquistas.

Às minhas avós Julia e Lourdes pelo amor e ensinamentos durante toda minha vida

Aos animais, por serem essenciais à vida humana, em especial, meus amados companheiros Francesca, Luigi, Filippo Tedesco e Minnie, por fazerem parte da minha história de vida e por estarem presentes em muitos pedaços deste trabalho, sempre transmitindo paz, cumplicidade e amor. 


\section{AGRADECIMENTOS}

A Deus, porque acima de tudo é a pessoa mais importante da minha vida, estando presente em todos os dias da minha caminhada, me transmitindo luz, fé, sabedoria e força para enfrentar os obstáculos que surgem no decorrer da nossa existência.

Ao Prof. Dr. José Soares Ferreira Neto, pela amizade, confiança e oportunidade em realizar esta dissertação.

As Profas. Simone e Evelise pela amizade e força durante a realização deste trabalho.

Aos Profs. Rodrigo Martins Soares e Paulo Eduardo Brandão, por me ajudarem na realização do projeto, sempre com disponibilidade em ajudar.

Ao Prof. Fernando Ferreira pela paciência e ajuda em toda parte estatística da minha dissertação.

Ao César Alejandro Rosales Rodrigues, pela amizade e apoio, e por transmitir seus conhecimentos moleculares durante a realização do trabalho.

A amiga Lara Borges Keid, pelo companheirismo, amizade e ensinamentos, que foram peças fundamentais para a realização total do projeto.

Aos amigos pós-graduandos e estagiários do Laboratório de Zoonoses

Bacterianas, Flávia, Amane, Vivianne, Flávia Carolina, Cássia, Carlos, Ricardo, Wilsilene, sobretudo pela amizade, convivência, força, apoio e ajuda durante todo o período do mestrado, à vocês meu muito obrigado.

À querida amiga Pilar, meu agradecimento especial pela amizade tão sincera, diversão, horas agradáveis de convivência durante os dias no laboratório e ajuda em grande parte da realização do meu projeto experimental. 
Á Gisele Oliveira de Souza e Zenaide Maria de Morais pela sempre disponibilidade, amizade e ensinamentos durante a realização do deste trabalho.

Aos amigos Sandra e Bispo pela força e apoio durante todo o período de pós.

Aos professores e funcionários do VPS, pela oportunidade, força e ensinamentos necessários na minha formação profissional.

A todos os pós-graduandos do VPS, em especial Alessandra, Vanessa, Sibele, Aldo, Anaiá, lara, Mauricio, Estela, Karen, Pati Pink e Dani Ribeiro pela amizade e por muitos momentos de convivência, estudo e ajuda.

Ao LABMAS por permitir o aprendizado de muitos conhecimentos moleculares, assim como por também ter sido importante na realização da parte experimental.

A Sheila Oliveira de Souza, pela amizade e força, sempre com muita disponibilidade em ajudar.

Ao Laboratório de Sanidade Suína Profa. Andréa Moreno e os pós: Renata, Sérgio, Tânia e Débora, pela amizade e grande ajuda na realização da parte experimental.

Aos secretários Virgínia, Cristina, Tânia, Danival pelo coleguismo e ajuda.

Às secretárias da pós-graduação da FMVZ-USP, Dayse, Claudia e Joana, por toda ajuda durante o período da pós.

A equipe da biblioteca da FMVZ-USP, pela atenção e profissionalismo, em especial Elza.

As minhas amigas Karina, Marcela, Carolina Mosca, Milena, Simone e Suelen, por muitos anos de amizade verdadeira, por me apoiarem em vários momentos da minha caminhada e por sempre transmitirem alegria e compreensão.

As sempre amigas Patrícia Borelli Noronha e Sabrina Caruso Chate, que são pessoas fundamentais em minha vida, pela amizade sincera e verdadeira, sempre me apoiando e incentivando mesmo perante as dificuldades. 
Às amigas Salesianas, por tantos anos de amizade e companheirismo, pelos inúmeros conselhos e ensinamentos humanitários ajudando em minha formação pessoal, sempre proporcionando muitas alegrias e exemplos de vida. A vocês, agradeço pelo muito que sou. 
Arriva fino a dove puoi vedere. Quando sei li potrai vedere più lontano (Thomas Carlyle)

Quem admira uma casa de linda construção, não irá dizer que foi o acaso que a construiu e organizou. Quem dissesse que um relógio se fez por si mesmo, seria desprezado como um louco. Assim, vendo a ordem e a magnífica harmonia que reina no universo, não se pode hesitar um só instante em crer em um Deus que criou, deu movimento a todas as coisas e as conserva. (San Giovanni Bosco - D. Bosco) 
Ser veterinário não é só cuidar dos animais...

É sobretudo amá-los, não ficando somente nos padrões éticos de uma ciência médica. Ser veterinário é acreditar na imortalidade da natureza e querer preservá-la sempre mais bela. É ouvir miados, mugidos, balidos, relinchos e latidos, e principalmente entendê-los. É gostar de terra molhada, de mato fechado, de luas e chuvas. Ser veterinário é não se importar se os animais pensam, mas sim se sofrem. É dedicar parte do seu ser à arte de salvar vidas. Ser veterinário é aproximar-se de instintos. É perder medos. É ganhar amigos de pêlos e penas, que jamais irão decepcioná-lo. Ser veterinário e não gostar de gaiolas, jaulas e correntes. É perder um tempo acompanhando rebanhos e vôos de gaivotas. É permanecer descobrindo, por intermédio dos animais, a si mesmo. Ser veterinário é ser o único capaz de entender rabos abanando, arranhões carinhosos e mordidas de afeto. É sentir cheiro de pêlo molhado, cheiro de almofada com essência de gato, cheiro de baias, de curral e de esterco. Ser veterinário é ter capacidade de compreender gratidões mudas, mas sem dúvida alguma, as únicas verdadeiras. É adivinhar olhares, é lembrar do seu tempo de criança, é querer levar para casa todos os animais sem dono. Ser veterinário é conviver lado a lado com ensinamentos profundos sobre o amor à vida.

(Autor desconhecido) 


\section{RESUMO}

MATRONE, M. Avaliação de diferentes protocolos de extração de DNA para detecção de Brucella abortus a partir de materiais colhidos de feto abortado ou bezerros nascidos de vacas experimentalmente infectadas com cepa 2308. [Evaluation of differents protocols of DNA extraction for Brucella abortus detection from aborted featus materials or from calves born from experimentally infected cows with 2308 strain]. 2008. 92 f. Dissertação (Mestrado em Medicina Veterinária) - Faculdade de Medicina Veterinária e Zootecnia, Universidade de São Paulo, São Paulo, 2008.

A Brucella abortus causa diminuição da eficiência reprodutiva em bovinos e é também o agente de uma das zoonoses mais difundidas no mundo. A doença é alvo de programas de controle em muitos países e, no Brasil, seu combate foi melhor organizado a partir de 2001, com o lançamento de programa nacional pelo MAPA. O objetivo do presente estudo foi aperfeiçoar a detecção de $B$. abortus em homogeneizados de órgãos de fetos abortados por vacas infectadas. Assim, foram comparados diferentes protocolos de extração de DNA, visando à detecção de $B$. abortus pela PCR em amostras clínicas colhidas de fetos abortados ou bezerros oriundos de vacas experimentalmente desafiadas com B. abortus cepa 2308. Para tanto, foram construídos dois grupos padrão ouro com base na bacteriologia clássica, constituídos por: 32 pulmões (17 positivos ao isolamento), 26 baços (11 positivos ao isolamento), 23 fígados (8 positivos ao isolamento) e 22 linfonodos bronquiais ( 7 positivos ao isolamento). Todas essas amostras foram submetidas a três distintos protocolos de extração de DNA, seguidos do mesmo processo de amplificação com os primers B4 e B5. A análise dos resultados consolidados mostrou uma sensibilidade de $95 \%$ para o protocolo da proteinase $\mathrm{K}(\mathrm{PK}), 86 \%$ para o do isotiocianato de guanidina (GT) e de $88 \%$ para o de Boom. Os valores encontrados de Sensibilidade para pulmão, baço, fígado e linfonodo foram, respectivamente, 100\%, $100 \%, 100 \%$ e $71 \%$ (PK), $82 \%, 100 \%, 88 \%$ e $71 \%$ (GT) e $94 \%, 100 \%$, 63\% e $86 \%$ (Boom). No grupo dos animais dos quais não foi possível isolar brucellas (gold standard negativo), a PCR resultou positiva em 8 amostras para o protocolo de extração PK (4 pulmões, 1 fígado e 3 linfonodos), em 6 amostras para o protocolo de extração GT (1 pulmão, 3 fígados e 2 linfonodos) e em 37 amostras para o protocolo de extração Boom (10 pulmões, 10 baços, 10 fígados e 7 linfonodos). Esses resultados permitem afirmar que o protocolo de extração $\mathrm{PK}$ apresentou a melhor sensibilidade diagnóstica e que o protocolo de extração de Boom apresentou o melhor desempenho nas amostras onde o isolamento foi negativo. Dentre os órgãos estudados, o baço apresentou a maior probabilidade de detecção de $B$. abortus. Assim, a melhor estratégia para detecção de $B$. abortus em homogeneizados de órgãos de fetos abortados é a utilização do isolamento e da PCR em paralelo.

Palavras-chave: Brucelose. Bovinos. Reação em Cadeia pela Polimerase. Brucella abortus. 
MATRONE,M.; Evaluation of differents protocols of DNA extraction for Brucella abortus detection from aborted featus materials or from calves born from experimentally infected cows with 2308 strain [Avaliação de diferentes protocolos de extração de DNA para detecção de Brucella abortus a partir de materiais colhidos de feto abortado ou bezerros nascidos de vacas experimentalmente infectadas com cepa 2308] 2008. 92 f. Dissertação (Mestrado em Medicina Veterinária) - Faculdade de Medicina Veterinária e Zootecnia, Universidade de São Paulo, São Paulo, 2008.

Infection by Brucella abortus diminishes the reproductive efficiency in bovines and it is also the agent of one of the most spread zoonosis in the world. In many countries control programs aim this disease, and in Brazil its combat was better organized since 2001 with the creation of the national program by the Ministry of Agriculture, Livestock and Supplies (MAPA). The objective of the present study was to improve the detection of $B$. abortus in aborted fetus homogenates from infected cows. For that reason, different DNA extraction protocols were compared, focusing the PCR detection of $B$. abortus in clinical samples collected from aborted fetus or calves obtained from cows experimentally defied with the 2308 B. abortus strain. Therefore, two gold standard groups were built based on classical bacteriology, formed by: 32 lungs (17 isolation positives samples), 26 spleens ( 11 isolation positives samples), 23 livers (8 isolation positives samples) and 22 bronchial lymph nodes (7 isolation positives samples). All samples were submitted to three distinct DNA extraction protocols, followed by the same amplification process with the primers B4 and B5. The analysis of the consolidated results showed a $95 \%$ sensibility for the proteinase $\mathrm{K}$ protocol (PK), $86 \%$ for the guanidine isotiocianate (GT) and $88 \%$ for the Boom. The sensibility values obtained for lungs, spleen, liver and lymph node were, respectively, $100 \%, 100 \%$, $100 \%$ and $71 \%$ (PK), $82 \%, 100 \%, 88 \%$ and $71 \%$ (GT) and $94 \%, 100 \%, 63 \%$ and $86 \%$ (Boom). In the group of animals in which it was not possible to isolate brucellas (negative gold standard), the PCR resulted positively in 8 samples for the PK extraction protocol (4 lungs, 1 liver and 3 lymph nodes), in 6 samples for the GT extraction protocol (1 lung, 3 livers and 2 lymph nodes) and in 37 samples for the Boom extraction protocol (10 lungs, 10 spleens, 10 livers and 7 lymph nodes). These results permit affirming that the PK extraction protocol showed the best diagnostic sensibility and that the Boom extraction protocol showed the best performance in negative isolation samples. Within the studied organs, the spleen showed the highest probability of $B$. abortus detection. Therefore, the best strategy for $B$. abortus detection in organs homogenates from aborted fetus is the utilization of isolation and in parallel, the PCR.

Keywords: Bovine. Brucellosis. Polymerase Chain Reaction. Brucella abortus. 


\section{LISTA DE FIGURAS}

FIGURA 1 - Gel de agarose mostrando resultado de PCR em amostras de linfonodo bronquial, pulmão, baço e fígado de feto abortado de vacas experimentalmente desafiadas com Brucella abortus 2308, utilizando extração enzimática do DNA por Proteinase K - São Paulo - 2008 .... 80

FIGURA 2 - Gel de agarose mostrando resultado de PCR em amostras de linfonodo bronquial, pulmão, baço e fígado de feto abortado de vacas experimentalmente desafiadas com Brucella abortus 2308, utilizando extração do DNA pelo Isotiocianato de Guanidina (GT) - São Paulo 2008

FIGURA 3 - Gel de agarose mostrando resultado de PCR em amostras de linfonodo bronquial, pulmão, baço e fígado de feto abortado de vacas experimentalmente desafiadas com Brucella abortus 2308, utilizando extração do DNA pelo Boom - São Paulo - 2008 


\section{LISTA DE GRÁFICOS}

GRAFICO 1 - Correlação entre a concentração de Brucella abortus $/ \mathrm{mL}$ e a concentração de DNA ( $\mu \mathrm{g} / \mathrm{mL})$ extraída pelo protocolo PK - São Paulo $-2008$ 48

GRAFICO 2 - Correlação entre a concentração de Brucella abortus $/ \mathrm{mL}$ e a concentração de DNA ( $\mu \mathrm{g} / \mathrm{mL})$ extraída pelo protocolo GT- São Paulo $-2008$ 48

GRAFICO 3 - Correlação entre a concentração de Brucella abortus $/ \mathrm{mL}$ e a concentração de DNA $(\mu \mathrm{g} / \mathrm{mL})$ extraída pelo protocolo do Boom - São Paulo - 2008 49

GRAFICO 4 -

Correlação entre as concentrações de DNA ( $\mu \mathrm{g} / \mathrm{mL})$ verificadas por três protocolos de extração de DNA de Brucella abortus - São Paulo2008

GRAFICO 5 - Correlação entre as razões das leituras de absorbância feitas com os comprimentos de onda 260 e $280 \mathrm{nM}$ para o protocolo de extração PK e diferentes concentrações de Brucella abortus/mL - São Paulo - 2008

GRAFICO 6 - Correlação entre as razões das leituras de absorbância feitas com os comprimentos de onda 260 e $280 \mathrm{nM}$ para o protocolo de extração GT e diferentes concentrações de Brucella abortus/mL - São Paulo - 2008

GRAFICO 7 - Correlação entre as razões das leituras de absorbância feitas com os comprimentos de onda 260 e $280 \mathrm{nM}$ para o protocolo de extração do Boom e diferentes concentrações de Brucella abortus/mL - São Paulo $-2008$

GRAFICO 8 - Correlação entre as razões das leituras de absorbância feitas com os comprimentos de onda 260 e $280 \mathrm{nM}$ verificadas por três protocolos de extração de DNA de Brucella abortus - São Paulo- 2008 54

GRAFICO 9 - Correlação entre as razões das leituras de absorbância feitas com os comprimentos de onda 260 e $280 \mathrm{nM}$ para três diferentes protocolos de extração de DNA de Brucella abortus em pulmão de fetos abortados de bovinos - São Paulo - 2008 57

GRAFICO 10 - Correlação entre as concentrações de DNA de Brucella abortus $(\mu \mathrm{g} / \mathrm{mL})$ obtidas por três protocolos de extração de amostras de pulmão de feto abortado de bovino - São Paulo - 2008 59 
GRAFICO 11 - Correlação entre as razões das leituras de absorbância feitas com os comprimentos de onda 260 e $280 \mathrm{nM}$ para três diferentes protocolos de extração de DNA de Brucella abortus em baço de fetos abortados de bovinos - São Paulo - 2008

GRAFICO 12 - Correlação entre as concentrações de DNA de Brucella abortus $(\mu \mathrm{g} / \mathrm{mL})$ obtidas por três protocolos de extração de amostras de baço de feto abortado de bovino - São Paulo - 2008

GRAFICO 13 - Correlação entre as razões das leituras de absorbância feitas com os comprimentos de onda 260 e $280 \mathrm{nM}$ para três diferentes protocolos de extração de DNA de Brucella abortus em fígado de fetos abortados de bovinos - São Paulo - 2008

GRAFICO 14 - Correlação entre as concentrações de DNA de Brucella abortus $(\mu \mathrm{g} / \mathrm{mL})$ obtidas por três protocolos de extração de amostras de fígado de feto abortado de bovino - São Paulo - 2008

GRAFICO 15 - Correlação entre as razões das leituras de absorbância feitas com os comprimentos de onda 260 e $280 \mathrm{nM}$ para três diferentes protocolos de extração de DNA de Brucella abortus em linfonodo bronquial de fetos abortados de bovinos - São Paulo - 2008 72

GRAFICO 16 - Correlação entre as concentrações de DNA de Brucella abortus $(\mu \mathrm{g} / \mathrm{mL})$ obtidas por três protocolos de extração de amostras de linfonodo bronquial de feto abortado de bovino - São Paulo - 2008 ...74 


\section{LISTA DE QUADROS}

QUADRO 1 - Seqüência dos primers utilizados para o diagnóstico de brucelose, através do gene codificador de $31 \mathrm{kDa}$ da proteína de membrana da Brucell - São Paulo,2008. 


\section{LISTA DE TABELAS}

TABELA 1 - $\quad$ Resultados do isolamento e da detecção de Brucella abortus 2308 pela PCR para três protocolos de extração de DNA, segundo diferentes concentrações bacterianas - São Paulo - 2008 46

TABELA 2 - $\quad$ Concentrações de DNA ( $\mu \mathrm{g} / \mathrm{mL})$ de Brucella abortus 2308 obtidas por três protocolos de extração de DNA, segundo diferentes concentrações bacterianas - São Paulo - 2008 47

TABELA 3 - $\quad$ Coeficiente de correlação de Pearson referente à comparação das concentrações de DNA $(\mu \mathrm{g} / \mathrm{mL})$ obtidas por três protocolos de extração de DNA de Brucella abortus - São Paulo- 2008 50

TABELA 4 - $\quad$ Razão entre as leituras de absorbância feitas com os comprimentos de onda 260 e $280 \mathrm{nM}$ para três protocolos de extração de DNA, segundo diferentes concentrações de Brucella abortus - São Paulo - 2008 ...51

TABELA 5 -

Coeficiente de correlação de Pearson resultante da comparação das razões das leituras de absorbância feitas com os comprimentos de onda 260 e $280 \mathrm{nM}$ entre os três protocolo de extração de DNA de Brucella abortus - São Paulo - 2008. 54

TABELA 6 -

Resultados da detecção de Brucella abortus pelo isolamento clássico e pela PCR realizada com três diferentes protocolos de extração de DNA em amostras de pulmão de fetos bovinos abortados - São Paulo 2008 55

TABELA 7 -

Razão entre as leituras de absorbância feitas com os comprimentos de onda 260 e $280 \mathrm{nM}$ para três protocolos de extração de DNA, segundo amostras de pulmão de fetos abortados bovinos - São Paulo $-2008$ 56

TABELA 8 Coeficiente de correlação de Pearson entre as razões das leituras de absorbância feitas com os comprimentos de onda 260 e $280 \mathrm{nM}$ para três diferentes protocolos de extração de DNA de Brucella abortus em pulmão de fetos abortados de bovinos - São Paulo - 2008 57

TABELA 9 - $\quad$ Concentrações de DNA $(\mu \mathrm{g} / \mathrm{mL})$ obtidas por três diferentes protocolos de extração aplicados em amostras de pulmão de fetos bovinos abortados - São Paulo - 2008 58

TABELA 10 - Coeficiente de correlação de Pearson entre as concentrações de DNA de Brucella abortus $(\mu \mathrm{g} / \mathrm{mL})$ obtidas por os três protocolos de extração em de pulmão de feto abortado de bovino - São Paulo - 2008 59 
TABELA 11 - Resultados da detecção de Brucella abortus pelo isolamento clássico e pela PCR realizada com três diferentes protocolos de extração de DNA em amostras de baço de fetos bovinos abortados - São Paulo - 2008

TABELA 12 - Razão entre as leituras de absorbância feitas com os comprimentos de onda 260 e $280 \mathrm{nM}$ para três protocolos de extração de DNA, segundo amostras de baço de fetos abortados bovinos - São Paulo - 2008 .. 61

TABELA 13 - Coeficiente de correlação de Pearson entre as razões das leituras de absorbância feitas com os comprimentos de onda 260 e $280 \mathrm{nM}$ para três diferentes protocolos de extração de DNA de Brucella abortus em baço de fetos abortados de bovinos - São Paulo - 2008 .

TABELA 14 - Concentrações de DNA $(\mu \mathrm{g} / \mathrm{mL})$ obtidas por três diferentes protocolos de extração aplicados em amostras de baço de fetos bovinos abortados - São Paulo - 2008

TABELA 15 - Coeficiente de correlação de Pearson entre as concentrações de DNA de Brucella abortus $(\mu \mathrm{g} / \mathrm{mL})$ obtidas por os três protocolos de extração em de baço de feto abortado de bovino - São Paulo - 2008 64

TABELA 16 -

Resultados da detecção de Brucella abortus pelo isolamento clássico e pela PCR realizada com três diferentes protocolos de extração de DNA em amostras de fígado de fetos bovinos abortados - São Paulo - 2008 65

TABELA 17 - Razão entre as leituras de absorbância feitas com os comprimentos de onda 260 e $280 \mathrm{nM}$ para três protocolos de extração de DNA, segundo amostras de fígado de fetos abortados bovinos - São Paulo - 200866

TABELA 18 - Coeficiente de correlação de Pearson entre as razões das leituras de absorbância feitas com os comprimentos de onda 260 e $280 \mathrm{nM}$ para três diferentes protocolos de extração de DNA de Brucella abortus em fígado de fetos abortados de bovinos - São Paulo - 2008 67

TABELA 19 - Concentrações de DNA $(\mu \mathrm{g} / \mathrm{mL})$ obtidas por três diferentes protocolos de extração aplicados em amostras de fígado de fetos bovinos abortados - São Paulo - 2008 68

TABELA 20 - Coeficiente de correlação de Pearson entre as concentrações de DNA de Brucella abortus $(\mu \mathrm{g} / \mathrm{mL})$ obtidas por os três protocolos de extração em de fígado de feto abortado de bovino - São Paulo - 2008

TABELA 21 - Resultados da detecção de Brucella abortus pelo isolamento clássico e pela PCR realizada com três diferentes protocolos de extração de DNA em amostras de linfonodo bronquial de fetos bovinos abortados - São Paulo - 2008 70 
TABELA 22 -

Razão entre as leituras de absorbância feitas com os comprimentos de onda 260 e $280 \mathrm{nM}$ para três protocolos de extração de DNA, segundo amostras de linfonodo bronquial de fetos abortados bovinos - São Paulo - 2008 71

TABELA 23 - Coeficiente de correlação de Pearson entre as razões das leituras de absorbância feitas com os comprimentos de onda 260 e $280 \mathrm{nM}$ para três diferentes protocolos de extração de DNA de Brucella abortus em linfonodo bronquial de fetos abortados de bovinos - São Paulo - 2008 72

TABELA 24 - Concentrações de DNA $(\mu \mathrm{g} / \mathrm{mL})$ obtidas por três diferentes protocolos de extração aplicados em amostras de linfonodo bronquial de fetos bovinos abortados - São Paulo - 2008 73

TABELA 25 - Coeficiente de correlação de Pearson entre as concentrações de DNA de Brucella abortus $(\mu \mathrm{g} / \mathrm{mL})$ obtidas por os três protocolos de extração em de linfonodo bronquial de feto abortado de bovino - São Paulo 2008 74

TABELA 26 -

Resultados da PCR para detecção de Brucella abortus realizada com três protocolos de extração de DNA em amostras de pulmão de feto abortado de bovino, segundo resultados da bacteriologia clássica São Paulo - 2008 75

TABELA 27 - Resultados da PCR para deteç̧ão de Brucella abortus realizada com três protocolos de extração de DNA em amostras de baço de feto abortado de bovino, segundo resultados da bacteriologia clássica São Paulo - 2008. 75

TABELA 28 - $\quad$ Resultados da PCR para deteç̧ão de Brucella abortus realizada com três protocolos de extração de DNA em amostras de fígado de feto abortado de bovino, segundo resultados da bacteriologia clássica São Paulo - 2008 76

TABELA 29 - Resultados da PCR para detecção de Brucella abortus realizada com três protocolos de extração de DNA em amostras de linfonodo bronquial de feto abortado de bovino, segundo resultados da bacteriologia clássica - São Paulo - 2008 76

TABELA 30 - Resultados consolidados por órgãos de feto abortado de bovino para detecção de Brucella abortus pela PCR realizada com três protocolos de extração de DNA, segundo resultados da bacteriologia clássica São Paulo - 2008 77

TABELA 31 - Resultados da PCR para detecção de Brucella abortus realizada com três protocolos de extração de DNA em amostras de pulmão de feto abortado de bovino experimentalmente infectado com a estirpe 2308 São Paulo - 2008 . 77 
TABELA 32 - $\quad$ Resultados da PCR para deteç̧ão de Brucella abortus realizada com três protocolos de extração de DNA em amostras de baço de feto abortado de bovino experimentalmente infectado com a estirpe 2308 São Paulo - 2008 78

TABELA 33 - Resultados da PCR para detecção de Brucella abortus realizada com três protocolos de extração de DNA em amostras de fígado de feto abortado de bovino experimentalmente infectado com a estirpe 2308 São Paulo - 2008 78

TABELA 34 - $\quad$ Resultados da PCR para detecção de Brucella abortus realizada com três protocolos de extração de DNA em amostras de linfonodo bronquial de feto abortado de bovino experimentalmente infectado com a estirpe 2308 - São Paulo - 2008 79

TABELA 35 - Resultados consolidados por órgãos de feto abortado de bovino experimentalmente infectado com a estirpe 2308 para detecção de Brucella abortus pela PCR realizada com três protocolos de extração de DNA - São Paulo - 2008 


\section{LISTA DE ABREVIATURAS}

\begin{tabular}{ll} 
dATP & desoxi-adenosina trifosfato \\
dCTP & desoxi-citosina trifosfato \\
dGTP & desoxi-guanosina trifosfato \\
DNA & ácido desoxirribonucléico \\
dTTP & desoxi-timidina trifosfato \\
EDTA & ácido etileno-diamino tetracético \\
GT & Tiocianato de Guanidina \\
HCl & ácido clorídrico \\
KDa & kilodalton \\
L & litro \\
$\mu L$ & microlitro \\
$\mu \mathrm{g} / \mathrm{mL}$ & micrograma por mililitro \\
mg & miligrama \\
mL & miliitro \\
M & molar (mol por litro) \\
MgCl2 & cloreto de magnésio \\
NaCl & Cloreto de sódio \\
nm & nanômetro \\
bp & base pair (pares de base) \\
PCR & reação em cadeia pela polimerase \\
pg & picograma \\
pH & potencial hidrogeniônico \\
pK & proteinase K \\
RNA & ácido ribonucléico \\
rpm & rotações por minuto \\
Taq & Thermus aquaticus \\
TBE & tris-borato-EDTA \\
TE & tampão Tris-EDTA \\
TRIS & Tris (hidroximetil) amino metano \\
Tris HCl & Tris (hidroximetil) amino metano com ácido clorídrico \\
UFC & Unidade Formadora de Colônia \\
X & vezes \\
\hline
\end{tabular}




\section{LISTA DE SÍMBOLOS}

$\begin{array}{ll}\% & \text { porcentagem } \\ { }^{\circ} \mathrm{C} & \text { graus Celsius } \\ > & \text { maior } \\ < & \text { menor } \\ = & \text { igual } \\ + & \text { mais }\end{array}$




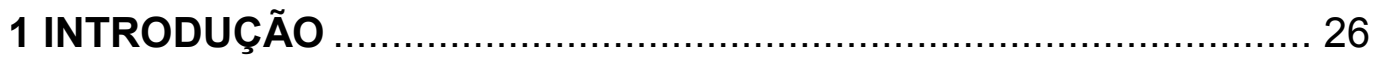

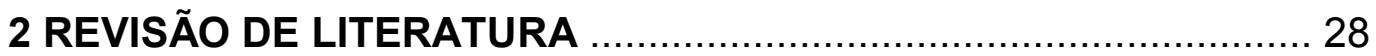

2.1 CARACTERÍSTICA DO AGENTE ................................................. 28

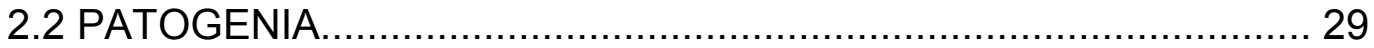

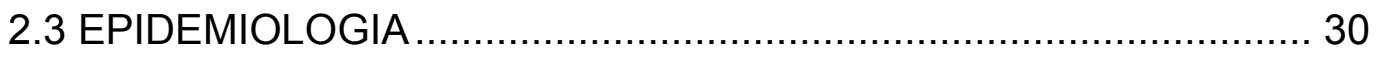

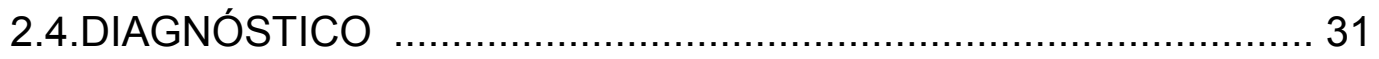

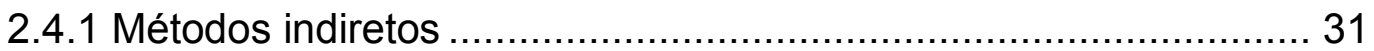

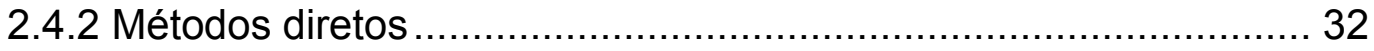

2.5 CONTROLE

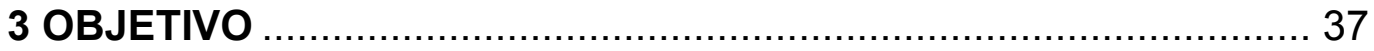

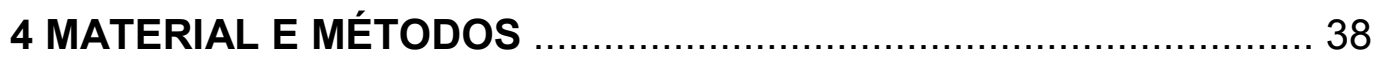

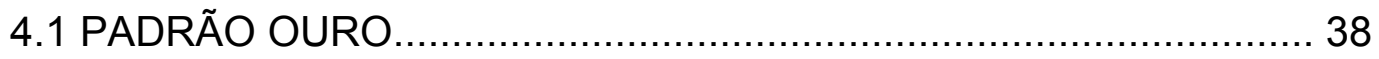

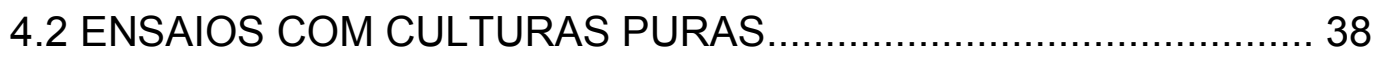

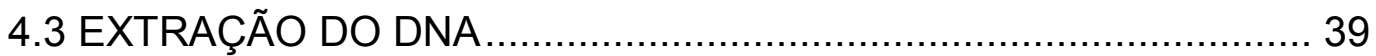

4.3.1 Protocolo 1 - Lise enzimática por Proteinase $\mathrm{K} e$

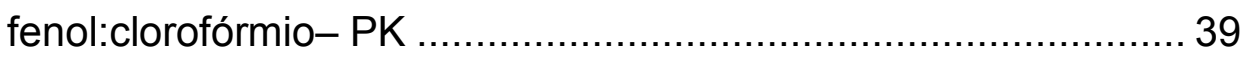

4.3.2 Protocolo 2 - Isotiocianato de Guanidina - GT ........................... 40

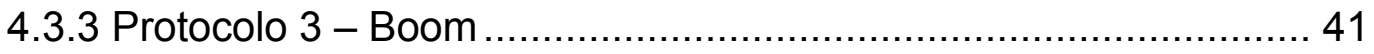

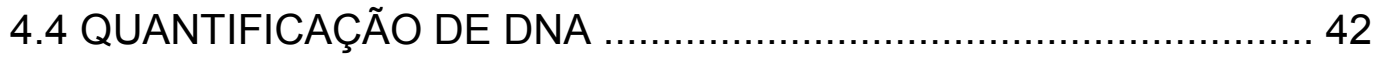

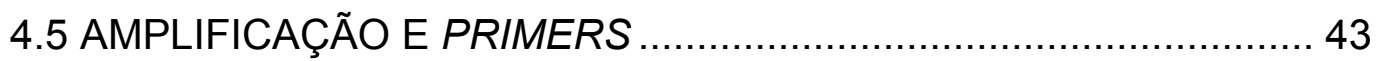


4.5.1 Para o protocolo da proteinase $\mathrm{k}$

4.5.2 Para o protocolo do GT 43

4.5.3 Para o protocolo do Boom 44

4.5.4 Para as amplificações foi adotado o seguinte ciclo 44

4.6 ANÁLISE DO PRODUTO AMPLIFICADO 44

4.7 CONTROLES 45

4.8 TRATAMENTO DOS DADOS 45

5 RESULTADOS 46

5.1 ENSAIOS COM CULTURAS PURAS. 46

5.2 COMPARAÇÃO DOS MÉTODOS DE EXTRAÇÃO DO DNA 54

5.2.1 Admitindo como gold standard o isolamento 54

5.2.2 Admitindo como gold standard a infecção experimental 77

6 DISCUSSÃo 83

6.1 ENSAIOS COM CULTURAS PURAS 83

6.2. ADMITINDO COMO GOLD STANDARD O ISOLAMENTO 84

6.3 ADMITINDO COMO GOLD STANDARD A INFECÇÃO EXPERIMENTAL 86

7 CONCLUSÕES 87 REFERÊNCIAS 88 


\section{INTRODUÇÃO}

A Brucella spp é uma bactéria Gram-negativa, intracelular facultativa que infecta animais domésticos e silvestres e também humanos. Nos animais a doença está relacionada a problemas reprodutivos e no homem geralmente produz quadros de infecção generalizada (PAULIN; FERREIRA NETO, 2003). Este gênero de bactérias se replica em fagócitos mononucleares do hospedeiro, inibindo os mecanismos extracelulares da resposta imune (SALDARRIAGA et al., 2002).

A brucelose bovina, causada pela Brucella abortus, é uma das zoonoses mais difundidas no mundo e alvo de programas de controle e erradicação em muitos países. $\mathrm{O}$ Brasil organizou melhor o combate à doença a partir de 2001, com o lançamento do Programa Nacional de Controle e Erradicação da Brucelose e Tuberculose (PNCEBT) (www.agricultura.gov.br).

Os programas de combate à brucelose apóiam-se na utilização de métodos diretos e indiretos de diagnóstico. Os indiretos são utilizados nas rotinas de certificação de propriedades livres e monitoradas (LAGE, 2006). Os métodos diretos são empregados para a comprovação bacteriológica de focos, no âmbito de sistemas de vigilância, implementados na fase de erradicação da doença. Classicamente, o diagnóstico direto é feito através de isolamentos em meios de cultura com posterior identificação dos isolados através de métodos bacteriológicos clássicos (PAULIN; FERREIRA NETO, 2003). As desvantagens desse método são o alto custo, o tempo necessário para crescimento e identificação das bactérias isoladas, além do alto risco para o operador (FEKETE, 1992).

Uma alternativa aos métodos bacteriológicos clássicos é a Reação em Cadeia de Polimerase (PCR), no qual se detecta um fragmento específico do DNA bacteriano presente nas amostras analisadas (PAULIN; FERREIRA NETO, 2003). Entretanto, poucos estudos têm sido realizados com amostras de campo para avaliar esta ferramenta diagnóstica (GULER et al., 2003).

Embora a PCR seja um método diagnóstico muito vantajoso pela sua rapidez e alta sensibilidade e especificidade (BRICKER, 2002; DAHOUK, 2003), possui também desvantagens que são alto custo, principalmente de equipamentos, e os fatores inibidores da amplificação do ácido nucléico, como proteínas séricas, debris celulares somáticos, polissacárides e outros componentes dos fluídos corpóreos (WILSON, 1997). Esses fatores inibidores são os principais responsáveis pelos resultados falsos negativos. A Comparação do genoma total das espécies de Brucella spp é importante para identificar 
os fatores responsáveis pela diferença de hospedeiros e a virulência (RAJASHEKARA et al., 2004).

Uma das formas de se detectar focos de brucelose no âmbito de um sistema de vigilância é a análise bacteriológica de fetos abortados (PAULIN; FERREIRA NETO, 2003). Os materias de eleição para a tentativa de isolamento de Brucella spp em fetos bovinos são liquido abomasal, suab retal, linfonodo bronquial, pulmão, fígado e baço (POESTER et al., 2006). Esses materiais, notadamente os fragmentos de órgãos, estão sujeitos à ação de inibidores da amplificação do ácido nucléico (WILSON, 1997). A solução para esse problema, diminuindo o número de falsos negativos à reação, pode ser o protocolo de extração do DNA.

Assim, tendo em vista a importância da análise bacteriológica do feto abortado para um sistema de vigilância de brucelose bovina e a ocorrência de falsos negativos à PCR quando a amostra clínica é representada por homogeneizado de órgãos, o presente projeto pretende comparar vários protocolos de extração de DNA em homogeneizados de órgãos. 


\section{REVISÃO DE LITERATURA}

\subsection{CARACTERÍSTICAS DO AGENTE}

Brucella é uma bactéria intracelular facultativa, Gram-negativa que pode infectar muitas espécies animais e o homem. São cocobacilos curtos, pequenos e pleomórficos, não formam cápsulas ou esporos e nem se movimentam ativamente (PAULIN; FERREIRA NETO, 2003; RIEMANN; CLIVER, 2006; CHU; WEYANT, 2003).

O gênero Brucella compreende 6 espécies: $B$ melitensis, $B$. abortus, $B$. suis e $B$. neotomae (grupo das lisas ou clássicas), B. ovis, B.canis (grupo das rugosas),No grupo das lisas ou clássicas algumas espécies são subdivididas em vários biovares ou biótipos (B. melitensis: 3 ; B. abortus: 7 ; B. suis: 4) que se identificam principalmente por testes bioquímicos (PAULIN; FERREIRA NETO, 2003; CIPOLLA et al.,2004; LAGE, 2006; ALTON et al., 1975). Recentemente, foram isoladas de mamíferos marinhos, duas novas espécies de Brucella, descritas através da diferenciação fenotipica e de características moleculares baseadas no polimorfismo do DNA no locus omp2 e preferência por hospedeiros, a B. cetaceae e B. pinnipidiae (CLOECKAERT et al., 2003).

As variantes lisas ou rugosas são reconhecidas através da morfologia da colônia e para algumas espécies quanto à virulência. A morfologia está relacionada com a composição do lipopolissacarídeo na membrana celular. As lisas possuem lipídeo A, núcleo oligossacáride e cadeia $\mathrm{O}$, já as rugosas possuem apenas lipídeo $\mathrm{A}$ e parte do núcleo oligossacáride (PAULIN; FERREIRA NETO, 2003; LAGE, 2006). Para algumas espécies de Brucella spp, o microorganismo virulento típico forma uma colônia lisa e transparente e tende sofrer mutação para forma rugosa, que é menos virulenta.

A maior proteína externa de membrana de Brucella spp foi identificada no início de 1980 e classificada de acordo com sua massa molecular em proteínas do grupo 2 (36-38 Kilodalton - kDa) e proteínas de grupo 3 (25-27 kDa e 31-34 kDa). Os genes omp 25 e omp 31 codificam para o grupo 3. A maior parte dos genes que codificam proteínas de membrana externa exibem diversidade entre espécies de Brucella spp, biovares e cepas, permitindo sua diferenciação e identificação de marcadores polimórficos que são utilizados em estudos filogenéticos e das variações antigênicas do gênero Brucella (CLOECKAERT et al., 1996).

A constituição da parede celular das brucelas confere a elas uma resistência importante ao meio ambiente. A associação de presença de umidade, sombreamento e 
baixas temperaturas aumentam a sobrevivência do agente no meio ambiente, ampliando sua chance de alcançar um novo suscetível. A luz solar direta diminui sua sobrevivência (PAULIN; FERREIRA NETO, 2003). Os métodos de pasteurização ou a fervura inativam a bactéria, que também é sensível a vários grupos de desinfetantes químicos (LAGE, 2006).

\subsection{PATOGENIA}

As principais portas de entrada da $B$. abortus são as mucosas oral, nasal, genital e ocular. Após a penetração na mucosa, as bactérias são fagocitadas, multiplicam-se nos linfonodos regionais e a partir daí poderão disseminar-se pela via hemática e linfática, albergando-se nos tecidos ricos em células mononucleares fagocitárias, podendo sobreviver por longos períodos dentro dos fagócitos, escapando assim da resposta imune (LAGE, 2006).

Uma vez que a Brucella spp é capaz de replicar-se intracelularmente, a resposta imune mediada por células é a mais importante nos fenômenos da relação hospedeiroparasita. A patogenia da infecção por Brucella spp é muito complexa, dependendo da espécie do microrganismo e do hospedeiro envolvidas. Dentre os elementos da imunidade celular têm destaque os macrófagos, as citocinas tipo Th 1 e as células citotóxicas (SALDARRIAGA et al., 2002).

Importante lembrar, que esta bactéria move-se através dos vasos linfáticos e se desloca pelos órgãos através da corrente sanguínea, instalando-se preferencialmente em baço, linfonodos, fígado, aparelho reprodutor masculino, úbere e útero. A Brucella tende a se multiplicar no útero de animais suscetíveis, onde seu crescimento é favorecido pela presença da substância eritritol, produzido no feto e nas membranas circundantes. As lesões necrótico-inflamatórias placentárias impedem a passagem de nutrientes e oxigênio da mãe para o feto, provocando assim, o aborto (TORTORA, 2000; LAGE, 2006). Em geral o aborto se dá na segunda metade da prenhez, causando retenção placentária ou metrites que podem ser causa de infertilidade permanente (ACHA; SZYFRES, 2001). O eritritol é um álcool poli-hídrico de quatro carbonos produzidos a partir dos líquidos alantoideano e amniótico bovino (PEARCE et al., 1961). Este álcool, não está presente na placenta humana (CARTER; CHENGAPPA, 1991).

A resistência de bovinos à infecção por Brucella pode ser influenciada pela idade, sexo e potencial reprodutivo de cada animal. Fêmeas em gestação são mais suscetíveis à infecção do que as jovens. Estas podem infectar-se por contato com fetos abortados ou 
placentas contaminadas com a bactéria (THOEN; ENRIGHT, 1988). Em touros, ocasionalmente a infecção localiza-se nos testículos, epidídimo ou vesícula seminal formando abscessos (IKRAM; HILL, 1991).

Nos bovinos infectados, a eliminação do agente se dá por descargas uterinas, sêmen e fezes. Quando o animal não está prenhe, excreta bactéria no leite (TORTORA, 2000), que se inicia após duas semanas do parto ou abortamento, podendo persistir por meses. Com a expulsão do feto, no parto ou abortamento, uma grande quantidade de bactérias é eliminada para o meio ambiente, contaminando pastagens, água e alimentos. O risco da transmissão venérea pela monta natural é muito baixo, porém alto pela inseminação artificial (PAULIN; FERREIRA NETO, 2003). As principais formas de transmissão para humanos é através do consumo de alimentos lácteos contaminados, contato direto/indireto com animais infectados e exposição acidental em laboratório que trabalha com o agente (MARIANELLI et al., 2007).

\subsection{EPIDEMIOLOGIA}

A Brucella abortus reconhecida primeiramente por Bang em 1897 (CARTER; CHENGAPPA, 1991), tem distribuição mundial, concentrando-se principalmente nos países em desenvolvimento da África, América do Sul, Oriente Médio e Ásia (PAULIN; FERREIRA NETO, 2003).

A Brucelose é uma zoonose re-emergente no mundo, causadora de grandes perdas econômicas diretas, relacionadas com a diminuição da performance reprodutiva nos animais de produção. Estimativas apontam a brucelose como a responsável pela diminuição na produção de leite e de carne e na produção de bezerros (LAGE, 2006).

A brucelose bovina no Brasil é conhecida desde 1922 e a bactéria causadora foi isolada de fetos abortados de bovinos no Estado de São Paulo em 1930 (MELLO, 1950). Garcia-Carrillo $^{1}$ (1987) apud Poester et al. em 2002 verificou a predominância dos biovares 1, 2 e 3 de $B$. abortus nos bovinos brasileiros, esta informação foi confirmada por Megid et al. em 2005, em um estudo realizado para caracterização dos biovares de Brucella abortus em bovinos abortados e fetos de búfalos d'água evidenciando também a infecção por $B$. abortus em búfalos d'água no país. 1 GARCÍA-CARRILLO, C. La brucellosis de los animales en América y su relacíon com la infeccíon humana. Office
International des Épizooties, Paris: $1987.43-70$ p. 
Dentre as perdas indiretas, vale lembrar que é a mais freqüente infecção bacteriana adquirida em laboratório, causando doenças em humanos com sinais inespecíficos, afetando vários órgãos. O contato com animais infectados, a ingestão de produtos lácteos contaminados e a exposição acidental em laboratório que trabalha com bacteriologia de Brucella são as formas de infecção humana mais importantes (DAHOUK et al., 2003).

A alta incidência da brucelose humana é encontrada em regiões onde existem costumes de consumir leites de cabra e bovino crus ou queijos macios preparados com leite não pasteurizado (BRICKER et al., 2003). Importante ressaltar que esta doença em humanos é rara em países que adotaram programas de erradicação (principalmente vacinação), contra brucelose bovina, ovina e caprina, entretanto, continua endêmica, na Bacia Mediterrânea, Centro Leste, Oeste da África e América do Sul (MAURIN, 2005).

\subsection{DIAGNÓSTICO}

\subsubsection{Métodos indiretos}

Embora sejam predominantemente direcionados para a pesquisa de anticorpos contra Brucella spp no soro, podem ser detectados em vários fluídos corporais. Existe intensa atividade científica visando o desenvolvimento e aperfeiçoamento de testes indiretos para brucelose bovina e os melhores deles estão referenciados e detalhados no Manual de Procedimentos para Testes Diagnósticos e Vacinas da Organização Mundial de Saúde Animal - OIE (www.oie.int).

Os principais testes para diagnosticar a brucelose bovina são: Soroaglutinação Lenta em Tubos(SLT), Soroaglutinação Rápida em Placa(SRP), Teste do Antígeno Acidificado tamponado ou Teste Rosa Bengala (AAT ou TRB), Reação de Fixação do Complemento(FC), Teste do 2-Mercaptoetanol(2-ME), Imunodifusão Radial Dupla, Testes Imunoenzimáticos (ELISA), Teste de Polarização da Fluorescência, Teste do Anel em Leite (TAL), Brucelina, Sêmen-plasma Aglutinação. A quantidade de testes é bastante ampla, sendo assim, cada país de acordo com sua disponibilidade, deve escolher os que melhor se adaptem à sua estratégia (www.oie.int). A OIE admite como teste de referência para comércio internacional e para a confirmação de diagnóstico a reação de FC e como teste de triagem o TRB. 
No Brasil, o Programa Nacional de Controle e Erradicação da Brucelose e Tuberculose (PNCEBT), definiu como teste individual de triagem o AAT e como confirmatórios os testes 2-ME e FC. Permite ainda o TAL para detecção de rebanhos infectados (LAGE, 2006).

Os testes sorológicos são utilizados nas rotinas de certificação de rebanhos livres (www.oie.int).

\subsubsection{Métodos diretos}

Os métodos diretos de diagnóstico para brucelose são utilizados para confirmação de focos bacteriológicos da doença e caracterização do agente circulante, embora resultados negativos não garantam a ausência da doença.

Classicamente é realizado a partir do isolamento e identificação do agente e suas espécies. Porém, a reação em cadeia pela polimerase também vem sendo muito utilizada como ferramenta para individualizar a Brucella spp em materiais suspeitos. Em caso de abortamento, recomenda-se a colheita de conteúdo gástrico, fígado, baço, rins e pulmão do feto abortado e dos linfonodos retrofaríngeos, mandibulares, parotídeos, supramamários, do úbere e cotilédone das carcaças de adultos para exame direto. Se o animal suspeito estiver vivo, pode-se tentar isolar a bactéria do leite, de muco vaginal e sêmen. (PAULIN; FERREIRA NETO, 2003).

No exame bacteriológico, os materiais suspeitos são semeados em meios de cultura especiais para multiplicação de Brucella spp, dentre os meios utilizados destacamse o Ágar Triptose e o Ágar-Brucella. O crescimento desta bactéria é lento, sendo assim, leva-se de 3 a 7 dias para que as colônias possam ser visualizadas (CARTER; CHENGAPPA, 1991). A identificação das espécies de Brucella spp pode ser feita através de provas bioquímicas que identificam diferenças metabólicas entre as espécies e biotipos. As principais provas são: necessidade de $\mathrm{CO} 2$, presença de $\mathrm{H} 2 \mathrm{~S}$, tionina, fucsina básica, aglutinação em soro, tempo de atividade da uréase entre outras (ALTON et al., 1975; METCALF et al., 1994). Uma vantagem deste método direto é a especificidade em detectar a presença da bactéria e as principais desvantagens são os riscos de contaminação acidental em laboratório e o tempo de crescimento bacteriano.

A PCR é uma técnica alternativa ou complementar ao isolamento, capaz de detectar um segmento de DNA específico de B. abortus em materiais suspeitos. Suas principais vantagens são: rapidez quando comparada ao isolamento, alta especificidade 
pela utilização de primers específicos com seqüências de DNA presentes na bactéria e alta sensibilidade (BRICKER, 2002; DAHOUK, 2003; LAGE, 2006). As principais desvantagens deste método são a presença de fatores inibidores do ácido nucléico e o alto custo de equipamentos e reagentes (PAULIN; FERREIRA NETO).

A discriminação das espécies de Brucella spp através de métodos moleculares é uma ferramenta epidemiológica muito importante para o controle da brucelose, mas os avanços são lentos pela homogeneidade genética deste gênero de bactérias (WHATMORE et al., 2006). Além disso, estudos genéticos moleculares demonstraram uma associação filogenética da Brucella spp com Agrobacterium, Phyllobacterium, Ochrobactrum e Rhizobium (ROMERO et al. 1995; DA COSTA et al., 1996; CORBEL, 1997).

A PCR para detecção de Brucella spp tem sido cada vez mais estudada.

Fekete et al. (1990), estudaram a sensibilidade e a especificidade diagnóstica da PCR para Brucella spp e obtiveram ótimos resultados de especificidade quando, na amplificação, a temperatura de anelamento era de $60^{\circ} \mathrm{C}$. Para testar a especificidade da reação, foram extraídos e testados DNA de 17 microorganismos possivelmente associados com infecções em bovinos, já a sensibilidade, foi determinada com diferentes concentrações de DNA de Brucella spp. Os resultados de especificidade e sensibilidade da PCR, juntamente com a simplicidade e rapidez do teste, sugeriram uma grande utilidade desta técnica em diagnóstico de rotina para a brucelose.

Baily et al. (1992), propuseram os primers B4 e B5, que amplificam um fragmento de 223 pares de bases (bp) a partir do gene codificador da proteína periplásmica imunogênica denominada BCSP31, de 31KDa de massa molecular. Este gene esta presente em todas as espécies de Brucella spp. B. O teste mostrou ser muito sensível e especifico em DNA de bactérias Gram-negativas patogênicas. Não existiu diferença entre B. melitensis e $B$. abortus quanto à sensibilidade da reação e ao produto amplificado.

Os primers B4 e B5, que amplificam uma seqüência de 223 bp do antígeno de Brucella abortus, foram também utilizados em amostras de soro e sangue humano e produziram uma boa resposta para diagnóstico confirmatório de brucelose humana através da PCR (MATAR et al., 1996; ZERVA et al., 2001).

A PCR foi utilizada para detectar as espécies de Brucella spp presentes em útero, baço, linfonodos, rins de três vacas naturalmente infectadas com brucelose. Os resultados da PCR foram comparados com os resultados da bacteriologia. Todas as 18 amostras testadas reagiram positivamente pela PCR, porém em 5 delas as bandas esperadas 
foram fracas. Estas mesmas 5 amostras foram negativas para o cultivo bacteriano, enquanto o restante das amostras foram positivas (GALLIEN et al., 1998).

Amostras de conteúdo estomacal de fetos abortados de ovelhas foram submetidas tanto ao cultivo quanto à extração do DNA pelo ciclo de fervura e congelamento antecedendo a PCR. Os resultados indicaram uma sensibilidade melhor da PCR, mostrando que a aplicação desta técnica pode ser promissora na identificação de animais infectados e assim, possivelmente substituir, os trabalhosos e demorados testes convencionais (ÇETINKAIA et al., 1999).

A PCR foi utilizada para diagnosticar a brucelose caprina e comparar a sensibilidade de algumas técnicas sorológicas e bacteriológicas rotineiramente usadas. Amostras de leite e sangue, de animais clinicamente saudáveis provenientes do México foram utilizadas para cultura microbiológica e extração do DNA pelo protoloco da proteinase K. Os soros foram testados com antígeno Rosa Bengala (RBT). Os resultados mostraram que $86 \%$ das amostras sanguíneas foram positivas para o teste da PCR, enquanto $60 \%$ foram positivas para o teste sorológico. A bactéria foi isolada somente em 1 cultura sanguínea. $64 \%$ das amostras de leite foram positivas para a PCR, mas fracassaram na cultura bacteriana. Testes bioquímicos e a PCR, demonstraram que a infecção estava associada com Brucella abortus biovar 1. O estudo demonstrou que a sensibilidade da PCR é superior a do RBT e a da cultura sanguínea, portanto a PCR é uma ferramenta de rápida identificação de cepas e espécies de Brucella (LEALKLEVEZAS et al., 2000).

Cortez et al. (2001), realizaram um estudo para padronização da técnica da PCR em amostras clínicas e experimentalmente infectadas de abortos bovinos. Na amplificação, utilizaram os primers B4 e B5 descritos por Baily et al. (1992). Os resultados apontam "boa" concordância entre a PCR e o cultivo de Brucella $(k=0,73)$, sendo que 7 amostras foram positivas tanto para o cultivo quanto para a PCR e 4 de 54 amostras negativas para cultivo, foram positivas para a PCR. Ambos os métodos testados para a extração do DNA (lise pela fervura e lise enzimática pela proteinase K) mostraram-se eficazes quanto à sensibilidade.

Um estudo foi realizado por Richtzenhain et al. (2002), com o objetivo de desenvolver um multiplex PCR (mPCR) para detecção de Brucella spp e Leptospira spp. Foram utilizados para a amplificação, os primers B4 e B5. O mPCR foi testado em 2 grupos de amostras clinicas: 1) 63 episódios de abortos em bovinos experimentalmente contaminados 2) 8 Hamsters infectados com Leptospira spp. De acordo com as 
referências para o isolamento microbiológico, o teste mostrou $100 \%$ de sensibilidade em ambos os grupos. Em 7 amostras coletadas de fetos abortados, as culturas foram negativas para Brucella spp, e positivas para o mPCR. O protocolo de fervura mostrou melhores resultados para algumas amostras clinicas, provavelmente, através do aquecimento ocorreu remoção de inibidores da PCR. A alta sensibilidade, simplicidade e a possibilidade de detecção da bactéria, possibilita o uso do mPCR em diagnóstico de rotina.

Padilla et al. (2003), realizaram um estudo de padronização da PCR para detecção de Brucella spp. Utilizaram dois métodos de extração de DNA: fenol-clorofórmio-alcool isoamílico e um kit comercial. Para determinarem a sensibilidade da prova, utilizaram 8 cepas peruanas de Brucella spp e para especificidade usaram cepas peruanas de outras bactérias. Como resultado obtiveram efetividade nos dois métodos de extração, com alta sensibilidade analítica da prova. A PCR detectou todas as cepas peruanas de Brucella spp e foi negativa para as outras bactérias. Desta maneira, uma PCR mais sensível e especifica foi padronizada em laboratório para cepas peruanas de Brucella spp.

Seonádh et al. (2006), desenvolveram um estudo de avaliação da viabilidade do convencional e da PCR em tempo real como ferramenta diagnóstica para detecção de Brucella abortus em vacas naturalmente infectadas. Amostras de leite, sangue e tecidos linfáticos foram coletados de animais naturalmente infectados. A B. abortus não foi detectada nas amostras de sangue coletadas de vacas naturalmente infectadas pelo convencional ou pela PCR em tempo real. Não existiu diferença entre a PCR e os métodos bacteriológicos.

\subsection{CONTROLE}

As estratégias de controle da brucelose visam a redução constante do número de focos da doença. Basicamente, isso é feito com a vacinação das fêmeas, o controle do trânsito dos animais de reprodução e a certificação de rebanhos livres, realizada pelo diagnóstico sistemático dos animais de reprodução, seguido do sacrifício dos positivos, combinados com medidas ambientais. O propósito da vacinação é reduzir a prevalência da doença com baixo custo. Os melhores resultados são alcançados quando cerca de $80 \%$ das fêmeas em idade de procriar estiverem imunizadas. A experiência internacional mostrou que quando essa cobertura vacinal for alcançada, a prevalência dos animais será inferior a 2\% (PAULIN; FERREIRA NETO, 2003). 
A vacina mais utilizada nos programas de controle é a B19, uma amostra lisa de B.abortus, naturalmente atenuada, que induz formação de anticorpos contra LPS liso, podendo interferir no diagnóstico da doença. A presença destes anticorpos está relacionada com a idade da vacinação, por isso, esta vacina deve ser empregada somente em fêmeas jovens com até 8 meses de idade. Não se recomenda a vacinação de machos ou fêmeas em gestação. Em meados dos anos 1990 foi desenvolvida uma nova vacina, a RB51, uma amostra de $B$. abortus rugosa, atenuada, originária de cepa 2308, que diminuiu sua virulência após sofrer inúmeras passagens em meio contendo rifampicina. Por ser rugosa, não provoca formação de anticorpos contra LPS liso, desta forma, não interfere no diagnóstico sorológico da doença (LAGE, 2006). Alguns países já permitem a sua utilização, em combinação ou não com a B19.

Atingida uma situação de baixa prevalência, a vacinação torna-se desnecessária, e as estratégias de controle devem ser trocadas pelas de erradicação, cujo objetivo passa a ser não apenas diminuição constante do número de focos, mas a eliminação de todos os focos. Dentre as estratégias de erradicação, destaca-se a detecção dos focos residuais. Essa detecção pode ser feita de várias maneiras: pesquisa de anticorpos no leite, sorologia em animais de reprodução descartados em abatedouro, sorologia para a movimentação de animais de reprodução, estudos por amostragem, busca ativa nos produtores informais, investigação de denúncias ou rumores, investigação de casos de brucelose humana, investigação de propriedades que mantém relação epidemiológica com o foco e, finalmente, investigação de abortos bovinos (PAULIN; FERREIRA NETO, 2003).

O ideal é que seja feita uma investigação bacteriológica nos abortos bovinos antes da intervenção na propriedade. Em caso de resultado positivo, haverá certeza da condição de foco da propriedade. A PCR pode melhorar a performance desse diagnóstico. 


\section{OBJETIVO}

Comparar vários protocolos de extração de DNA em quatro distintos órgãos (pulmão, fígado, baço e linfonodo bronquial) provenientes de fetos abortados e bezerros nascidos de vacas experimentalmente infectadas com a B. abortus 2308 por volta do quinto mês de gestação. 


\section{MATERIAL E MÉTODOS}

\subsection{PADRÕES OURO}

Os grupos de padrões ouro, tanto positivo quanto negativo, são amostras de homogeneizado de órgãos originadas de um experimento de teste clínico de vacinas realizado no Laboratório de Zoonoses bacterianas na Faculdade de Medicina Veterinária e Zootecnia da Universidade de São Paulo (USP) denominado "Avaliação de vacina contra brucelose bovina não indutora de anticorpos (VNIA)", financiado pela FAPESP (Protocolo $N^{\circ}$ 296/2003). Todas as amostras a serem examinadas foram provenientes de fetos abortados ou bezerros nascidos prematuros de vacas desafiadas com a $B$. abortus 2308 por volta do quinto mês de gestação.

O grupo padrão ouro positivo foi composto por 17 amostras de pulmões, 11 de baços, 8 de fígados e 7 de linfonodos bronquiais. O grupo padrão ouro negativo foi composto por 15 amostras de cada um desses mesmos órgãos dos quais não se logrou 0 isolamento de $B$. abortus 2308.

\subsection{ENSAIOS COM CULTURAS PURAS}

O ensaio de culturas puras da cepa 2308 de Brucella abortus foi realizado a partir do repique inicial da bactéria, em meio de cultura de ágar triptose com adição de soro fetal bovino $5 \%$.

Para iniciar as diluições de Brucella, foi coletada uma alçada do repique inicial e colocada em salina até que apresentasse a mesma turvação da escala 0,5 de McFarland, que corresponde a $1,5 \times 10^{8}$ bactérias.

A partir desta concentração de $10^{8}$ (equivalente à escala 0,5 ), foram feitas diluições até escala de $10^{-10}$, ou seja, $10^{8}, 10^{7}, 10^{6}, 10^{5}, 10^{4}, 10^{3}, 10^{2}, 10^{1}, 10^{0}, 10^{-1}, 10^{-2}, 10^{-3}, 10^{-4}$, $10^{-5}, 10^{-6}, 10^{-7}, 10^{-8}, 10^{-9}, 10^{-10}$, da seguinte maneira:

Após adição da bactéria no tubo inicial contendo $9 \mathrm{~mL}$ de salina, transferiu-se $1 \mathrm{~mL}$ da solução contendo bactéria de um tubo para outro, cada um também com $9 \mathrm{~mL}$ de salina até a menor diluição que no caso deste trabalho foi $10^{-10}$.

- $\quad 100 \mu \mathrm{L}$ de cada uma das diluições foi cultivado em placas com meio de Ágar Triptose e após 4 dias observou-se o crescimento bacteriano. 
$400 \mu \mathrm{L}$ de cada uma das diluições foram utilizados para extração de DNA por cada um dos protocolos testados neste projeto e seus respectivos PCR.

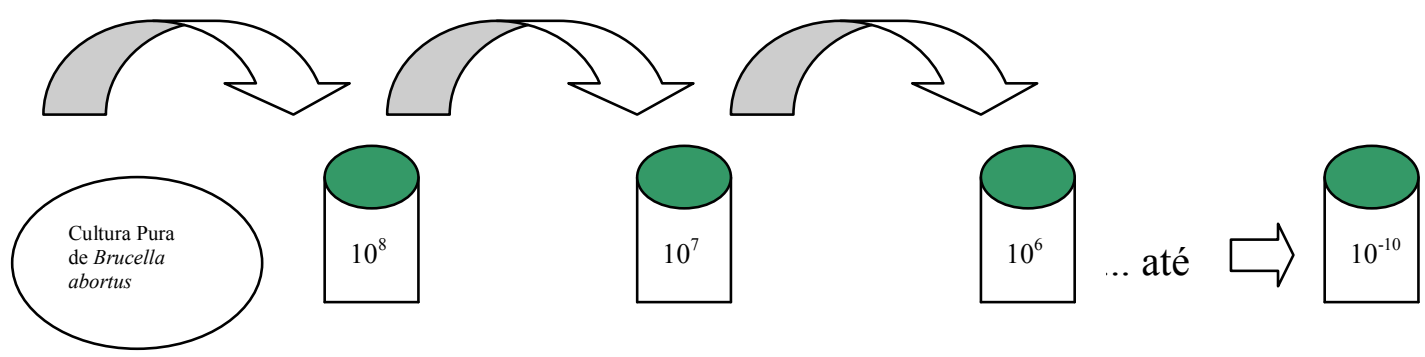

\subsection{EXTRAÇÃO DO DNA}

Todas as amostras tanto infectadas quanto não infectadas serão submetidas a 4 diferentes protocolos para extração de DNA.

4.3.1 Protocolo 1 - Lise enzimática por Proteinase $\mathrm{K}$ e fenol:clorofórmio - PK (adaptado de Leal et al., 1995)

A reação foi realizada em microtubos de $1500 \mu \mathrm{L}$.

- Adicionar $400 \mu \mathrm{L}$ da amostra previamente homogeneizada.

- Adicionar $400 \mu \mathrm{L}$ de TE em controles negativos.

- Adicionar $1000 \mu \mathrm{L}$ de TE em cada amostra.

- Agitar por 10 segundo em vórtex.

- Centrifugar a 13000 x g/ 5 minutos.

- Desprezar o sobrenadante (repetir este procedimento até a suspensão ficar límpida).

- Ressuspender o sedimento em $300 \mu \mathrm{L}$ de tampão de lise $[10 \mu \mathrm{L}$ de pK 20 units/mg, $50 \mu \mathrm{L}$ de dodecil sulfato de sódio (SDS) a $10 \%, 5 \mu \mathrm{L}$ Tris-HCL 1M, $25 \mu \mathrm{L}$ EDTA 0,5 M, $10 \mu \mathrm{L}$ NaCL $5 \mathrm{M}$ e $400 \mu \mathrm{L}$ de água ultrapura].

- Incubar em banho-seco a $37^{\circ} \mathrm{C} /$ overnight a $600 \mathrm{rpm}$.

- Adicionar $500 \mu \mathrm{L}$ de fenol.

- Agitar por 20 segundos em vórtex. 
- Centrifugar a $13000 \times \mathrm{g} / 5$ minutos.

- Transferir $300 \mu \mathrm{L}$ da fase aquosa para novo tubo de $1500 \mu \mathrm{L}$, tomando-se cuidado de não aspirar à interface orgânica.

- Adicionar $300 \mu \mathrm{L}$ fenol-clorofórmio (150 $\mu \mathrm{L}$ de fenol + $150 \mu \mathrm{L}$ de clorofórmio).

- Agitar por 10 segundos em vórtex.

- Centrifugar 13000 x g/ 5minutos.

- Transferir $200 \mu \mathrm{L}$ da fase aquosa para novo tubo de $1500 \mu \mathrm{L}$, tomando-se cuidado de não aspirar a interface orgânica.

- Adicionar $200 \mu \mathrm{L}$ de propanol.

- Homogeneizar por inversão.

- Manter a $-20^{\circ} \mathrm{C}$ por 4 horas.

- Centrifugar a 13000 x g/ 30 minutos.

- Desprezar o sobrenadante e acrescentar $500 \mu \mathrm{L}$ de etanol $70 \%$.

- Centrifugar a 13000 x g/ 30 minutos.

- Descartar o sobrenadante por inversão e deixar secar a temperatura ambiente.

- Adicionar $30 \mu \mathrm{L}$ de TE pH 8,0.

- Incubar em banho - seco à $56^{\circ} \mathrm{C} / 15$ minutos.

- Estocar a $-20^{\circ} \mathrm{C}$.

4.3.2 Protocolo 2 - Isotiocianato de Guanidina - GT (adaptado de CHOMKZYNSKI, 1993)

- Colocar $400 \mu \mathrm{L}$ amostra $+900 \mu \mathrm{Lde}$ GT (60g de isotiocianato de guanidina $+5 \mathrm{~mL}$ de TRIS-HCl $1 \mathrm{M} \mathrm{pH} \mathrm{7,5+10} \mathrm{mL} \mathrm{de} \mathrm{EDTA} \mathrm{0,25} \mathrm{M} \mathrm{pH} \mathrm{8,0} \mathrm{+} 100 \mathrm{~mL}$ de fenol + ddH2O qsp $100 \mathrm{~mL}$ ) em um novo microtubo de $1500 \mu \mathrm{L}$.

- Vórtex 15 segundos $\rightarrow$ aguardar 10 minutos com novo vórtex ao final $\rightarrow$ spin.

- Acrescentar $200 \mu \mathrm{L}$ clorofórmio $\rightarrow$ vórtex 15 segundos $\rightarrow$ descansar 10 minutos.

- Centrifugar $12000 \mathrm{G}$ por 5 minutos.

- Recuperar o sobrenadante $(700 \mu \mathrm{L})$ e adicionar igual volume de propanol $(700 \mu \mathrm{L}$ para insolubilizar o DNA)- homogeneizar manualmente.

- Congelar à $-20^{\circ} \mathrm{C}$ por 2 horas.

- Centrifugar $12000 \mathrm{G}$ por 20 minutos.

- Desprezar o material com cuidado.

- Colocar $500 \mu \mathrm{L}$ etanol $70 \% \rightarrow$ homogeneizar manualmente. 
- Centrifugar $12000 \mathrm{G}$ por 10 minutos.

- Desprezar o sobrenadante e deixar secar em temperatura ambiente sobre um papel toalha.

- Adicionar $30 \mu \mathrm{L}$ de TE $\rightarrow$ vórtex $\rightarrow$ spin rápido.

- Banho seco $56^{\circ} \mathrm{C}$ por 15 minutos.

- Acondicionar em freezer $-20^{\circ} \mathrm{C}$.

4.3.3 Protocolo 3- Boom (adaptado de Boom et al.,1990).

- Transferir 400 ul do homogeneizado para um microtubo de $1500 \mu \mathrm{L}$.

- Adicionar $1000 \mu \mathrm{L}$ de tampão de lise $(120 \mathrm{~g}$ GuSCN - $10 \mathrm{~mL}$ de $1 \mathrm{M}$ TRIS-HCL pH 6,4 - 8,8 $\mathrm{mL}$ de EDTA 0,5 M pH 8,0 - $1 \mathrm{~mL}$ Triton x100).

- Homogeneizar por 2 minutos em vórtex.

- Acrescentar $40 \mu \mathrm{L}$ da suspensão carreadora $(1 \mathrm{~g}$ de Diatomaceous earth - $50 \mu \mathrm{L}$ de $\mathrm{HCL} 37 \%$ - $5 \mathrm{~mL}$ de água ultrapura).

- Homogeneizar por 1 minuto em vórtex.

- Deixar descansar por 20 minutos.

- Centrifugar a $12800 \times \mathrm{g} / 2$ minutos a $4^{\circ} \mathrm{C}$.

- Remover o sobrenadante cuidadosamente.

- Adicionar $500 \mu \mathrm{L}$ do tampão de lavagem (120g de GuSCN - $10 \mathrm{~mL}$ de $1 \mathrm{M}$ TRIS$\mathrm{HCL}$ pH 6,4 e $100 \mathrm{~mL}$ de água ultrapura) ao pellet.

- Homogeneizar por 1 minuto em vórtex.

- Centrifugar a $12800 \mathrm{x} \mathrm{g/2}$ minutos a $4^{\circ} \mathrm{C}$.

- Descartar o sobrenadante.

- Adicionar $500 \mu \mathrm{l}$ do tampão de lavagem ao pellet.

- Homogeneizar por 1 minuto em vórtex.

- Centrifugar a $12800 \mathrm{x} \mathrm{g} / 2$ minutos a $4^{\circ} \mathrm{C}$.

- Descartar o sobrenadante.

- Adicionar $500 \mu \mathrm{l}$ de etanol $70 \%$.

- Homogeneizar por 1 minuto em vórtex.

- Centrifugar a $12800 \mathrm{x} \mathrm{g/} 2$ minutos a $4^{\circ} \mathrm{C}$.

- Descartar o sobrenadante.

- Adicionar $500 \mu \mathrm{l}$ de etanol 70\%. 
- Homogeneizar por 1 minuto em vórtex.

- Centrifugar a $12800 \mathrm{x} \mathrm{g/2}$ minutos a $4^{\circ} \mathrm{C}$.

- Descartar o sobrenadante.

- Adicionar $500 \mu \mathrm{l}$ de acetona.

- Homogeneizar por 1 minuto em vórtex.

- Centrifugar a $12800 \times \mathrm{g} / 2,5$ minutos a $4^{\circ} \mathrm{C}$.

- Descartar o sobrenadante.

- Deixar tubo aberto em estufa de $37^{\circ} \mathrm{C} /$ por no mínimo 30 minutos.

- Adicionar $150 \mu \mathrm{L}$ de tampão de eluição (1 mL de TRIS-HCL 1M - 0,2 mL de EDTA pH 8,0 e 98,8 mL de água ultrapura).

- Agitar por 1 minuto em vórtex.

- Incubar em banho seco à $55^{\circ} \mathrm{C} / 10$ minutos.

- Agitar por 1 minuto em vórtex.

- Centrifugar a 12800 x g/ 5 minutos.

- Transferir $90 \mu \mathrm{L}$ da fase aquosa para novo tubo de $1500 \mu \mathrm{L}$ tomando-se cuidado de não aspirar a interface orgânica.

- Centrifugar a 12800 x g/ 5 minutos.

- Estocar a temperatura de $-20^{\circ} \mathrm{C}$.

\subsection{QUANTIFICAÇÃO DE DNA}

Alíquotas da solução de DNA de cada amostra-padrão oriunda do ensaio de culturas puras, bem como alíquotas da solução de DNA obtidas das amostras de homogeneizado de órgãos para os três protocolos de extração de DNA, foram diluídas 1:100 em água ultrapura obtida em aparelho Milli-Q-Millipore INC (Billerica MA USA) e submetidas à leitura espectrofotométrica nos comprimentos de onda $260 \mathrm{nM}$ e $280 \mathrm{nM}$, em espectrofotômetro BECKMAN DU® 640 (BECKMAN, FULLERTON, CA, USA). A quantificação foi realizada para avaliar a qualidade e a concentração de DNA como realizada por Vieira (2004). 


\subsection{AMPLIFICAÇÃO E "PRIMERS"}

Foram utilizados para a amplificação o par de primers $\mathrm{B}_{4}$ e $\mathrm{B}_{5}$ (Quadro 1) descritos por Baily et al. (1992), que podem ser observados no quadro 1. Estes primers amplificam um fragmento de $223 \mathrm{bp}$.

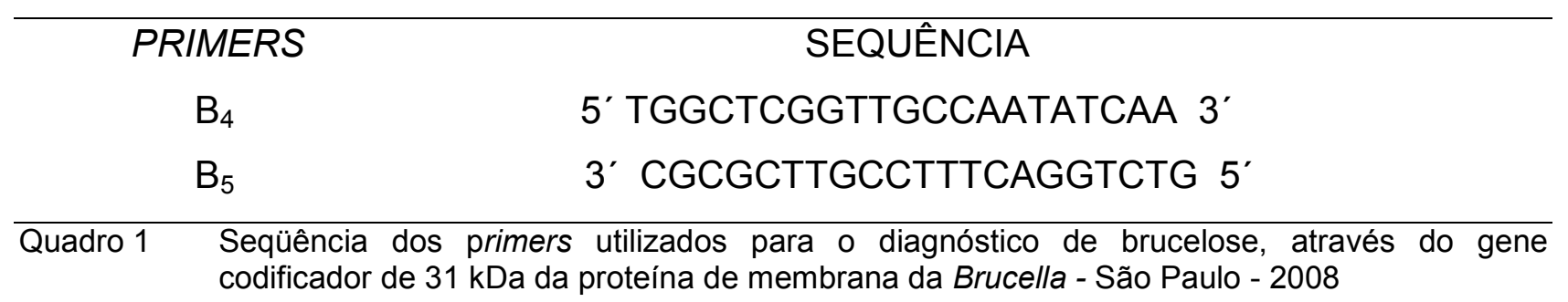

A amplificação do DNA da bactéria Brucella abortus foi feita através do protocolo de CORTEZ et al (2001):

4.5.1 Para o protoloco da Proteinase K:

- $22,5 \mu \mathrm{L}$ de água ultrapura

- $5 \mu \mathrm{L}$ de tampão de reação $10 \times(500 \mathrm{nM} \mathrm{KCL} ; 15 \mathrm{nM} \mathrm{MgCl}, 100 \mathrm{nM}$ Tris- HCL, pH 9,0)

- $8,0 \mu \mathrm{L}$ da mistura de dNTPs (200 nM de cada nucleotídeo [dCTP, dATP, dGTP, dTTP])

- $1,5 \mu \mathrm{L}$ de $\mathrm{MgCl}_{2}(50 \mathrm{nM})$

- $5 \mu \mathrm{L}$ do primer $\mathrm{B}_{4}(10 \mathrm{pmol} / \mu \mathrm{L})$

- $5 \mu \mathrm{L}$ do primer $\mathrm{B}_{5}(10 \mathrm{pmol} / \mu \mathrm{L})$

- $0,5 \mu \mathrm{L}$ de Taq DNA polimerase (5 unidades por $\mu \mathrm{L}$ )

- $2,5 \mu \mathrm{L}$ da amostra de DNA extraído

\subsubsection{Para o protocolo GT:}

- $\quad 22,5 \mu \mathrm{L}$ de água ultrapura

- $5 \mu \mathrm{L}$ de tampão de reação $10 \times(500 \mathrm{nM} \mathrm{KCL} ; 15 \mathrm{nM} \mathrm{MgCl} 2,100 \mathrm{nM}$ Tris- HCL, pH 9,0)

- $8,0 \mu \mathrm{L}$ da mistura de dNTPs (200 nM de cada nucleotídeo [dCTP, dATP, dGTP, dTTP])

- $1,5 \mu \mathrm{L}$ de $\mathrm{MgCl}_{2}(50 \mathrm{nM})$

- $5 \mu \mathrm{L}$ do primer $\mathrm{B}_{4}(10 \mathrm{pmol} / \mu \mathrm{L})$

- $5 \mu \mathrm{L}$ do primer $\mathrm{B}_{5}(10 \mathrm{pmol} / \mu \mathrm{L})$ 
- $\quad 0,5 \mu \mathrm{L}$ de Taq DNA polimerase (5 unidades por $\mu \mathrm{L}$ )

- $2,5 \mu \mathrm{L}$ da amostra de DNA diluído em TE na proporção $1: 5$, ou seja $2 \mu \mathrm{L}$ DNA + 6 $\mu \mathrm{L}$ de TE.

\subsubsection{Para o protocolo do Boom:}

- $20 \mu \mathrm{L}$ de água ultrapura

- $5 \mu \mathrm{L}$ de tampão de reação $10 \times(500 \mathrm{nM} \mathrm{KCL} ; 15 \mathrm{nM} \mathrm{MgCl}$, $100 \mathrm{nM}$ Tris- HCL, pH 9,0)

- 8,0 $\mu \mathrm{L}$ da mistura de dNTPs (200 nM de cada nucleotídeo [dCTP, dATP, dGTP, dTTP])

- $1,5 \mu \mathrm{L}$ de $\mathrm{MgCl}_{2}(50 \mathrm{nM})$

- $5 \mu \mathrm{L}$ do primer $\mathrm{B}_{4}(10 \mathrm{pmol} / \mu \mathrm{L})$

- $5 \mu \mathrm{L}$ do primer $\mathrm{B}_{5}(10 \mathrm{pmol} / \mu \mathrm{L})$

- $\quad 0,5 \mu \mathrm{L}$ de Taq DNA polimerase (5 unidades por $\mu \mathrm{L}$ )

- $5 \mu \mathrm{L}$ da amostra de DNA

4.5.4 Para as amplificações foi adotado o seguinte clico, descrito por BAILY et al. (1992):

- Desnaturação inicial: $94^{\circ} \mathrm{C}$ por 5 minutos

- Desnaturação do DNA: $94^{\circ} \mathrm{C}$ por 1 minuto - repetir 40 vezes

- Hibridização: $60^{\circ} \mathrm{C}$ por 1 minuto - repetir 40 vezes

- Extensão: $72^{\circ} \mathrm{C}$ por 1 minuto - repetir 40 vezes

- Extensão final: $72^{\circ} \mathrm{C}$ por 10 minutos

\subsection{ANÁLISE DO PRODUTO AMPLIFICADO}

A visualização do produto amplificado foi realizada através da técnica de eletroforese, em uma cuba horizontal, usando tampão de corrida TBE 0,5X (0,045M Trisborato e $1 \mathrm{mM}$ EDTA, ph 8,0$)$, agarose a $1,5 \%(\mathrm{p} / \mathrm{v})$ e uma voltagem constante de 6-7 $\mathrm{V} / \mathrm{cm}$.

A imersão do gel foi feita, em uma solução de $0,5 \mu \mathrm{g} / \mathrm{mL}$ de brometo de etídio por 20 minutos, e posterior observação em transiluminador ultravioleta (SAMBROOK et al., 1989). As bandas visualizadas foram comparadas com um padrão de peso molecular de fragmentos múltiplos de 100 pares de base. 


\subsection{CONTROLES}

Foram tomadas precauções para evitar a contaminação de utensílios e equipamentos de laboratório com material genético (DIEFFENBACH et al., 1995), diminuindo-se dessa forma o risco de falsos positivos na reação. Controles positivos e negativos foram utilizados em todas as reações.

\subsection{TRATAMENTO DOS DADOS}

Para cada um dos protocolos foram calculados os valores da sensibilidade e especificidade diagnóstica. As comparações de médias foram feitas considerando-se amostras pareadas. Para as amostras com distribuição normal foi utilizada a análise de variância para medidas repetidas e Tukey Kramer como pós-teste. Para as amostras com distribuição não normal foi utilizado o teste de Friedman e Dunn como pós-teste. O grau de correlação foi medido pelo coeficiente de correlação de Pearson. As comparações de proporções foram feitas pelo teste qui-quadrado. 


\section{RESULTADOS}

\subsection{ENSAIOS COM CULTURAS PURAS}

A tabela 1 traz os resultados da sensibilidade analítica obtida para cada um dos métodos de extração de DNA. As tabelas 2 e 4 mostram os resultados da quantificação de DNA e da razão das quantidades de DNA obtidas utilizando-se diferentes absorbâncias, respectivamente.

Tabela 1- Resultados do isolamento e da detecção de Brucella abortus 2308 pela PCR para três protocolos de extração de DNA, segundo diferentes concentrações bacterianas - São Paulo 2008

\begin{tabular}{|c|c|c|c|c|}
\hline \multirow{2}{*}{$\begin{array}{c}\text { Número de } \\
\text { bactérias } / \mathrm{mL}^{*}\end{array}$} & \multirow{2}{*}{$\begin{array}{c}\text { Isolamento } \\
\text { Brucella abortus }\end{array}$} & \multicolumn{3}{|c|}{ Protocolos de extração de DNA } \\
\hline & & PK & GT & BOOM \\
\hline $10^{8}$ & + & + & + & + \\
\hline $10^{7}$ & + & + & + & + \\
\hline $10^{6}$ & + & + & + & + \\
\hline $10^{5}$ & + & + & + & + \\
\hline $10^{4}$ & + & + & - & + \\
\hline $10^{3}$ & + & + & - & + \\
\hline $10^{2}$ & + & + & - & + \\
\hline $10^{1}$ & + & + & - & + \\
\hline $10^{0}$ & - & + & - & - \\
\hline $10^{-1}$ & - & + & - & - \\
\hline $10^{-2}$ & - & + & - & - \\
\hline $10^{-3}$ & - & - & - & - \\
\hline $10^{-4}$ & - & - & - & - \\
\hline $10^{-5}$ & - & - & - & - \\
\hline $10^{-6}$ & - & - & - & - \\
\hline $10^{-7}$ & - & - & - & - \\
\hline $10^{-8}$ & - & - & - & - \\
\hline $10^{-9}$ & - & - & - & - \\
\hline $10^{-10}$ & - & - & - & - \\
\hline
\end{tabular}

* foi preparada suspensão de colônias com turvação correspondente ao tubo 0,5 da escala de Mc Farland $\left(10^{8}\right.$ bactérias $\left./ \mathrm{mL}\right)$ e a partir desta foram feitas diluições de razão 10. 
As amostras entre $10^{8}$ a $10^{4}$ bactérias $/ \mathrm{mL}$ apresentaram incontável número de unidades formadoras de colônia (UFC) nos cultivos quantitativos e as amostras com $10^{3}$, $10^{2}$ e $10^{1}$ bactérias $/ \mathrm{mL}$ apresentaram 4.200, 240 e 50 UFC/mL. As amostras de $10^{0}$ até $10^{-10}$ bactérias/mL não apresentaram crescimento.

Tabela 2- Concentrações de DNA ( $\mu \mathrm{g} / \mathrm{mL})$ de Brucella abortus 2308 obtidas por três protocolos de extração de DNA, segundo diferentes concentrações bacterianas - São Paulo - 2008

\begin{tabular}{c|ccc}
\hline $\begin{array}{c}\text { Número de } \\
\text { bactérias } / \mathrm{mL}^{*}\end{array}$ & PK & $\begin{array}{c}\text { Protocolos de extração de DNA } \\
\text { GT }\end{array}$ & BOOM \\
\hline $10^{8}$ & 12,09 & 7,50 & 10,11 \\
$10^{7}$ & 6,56 & 5,01 & 0,64 \\
$10^{6}$ & 1,09 & 15,81 & 0,57 \\
$10^{5}$ & 5,14 & 2,40 & 0,55 \\
$10^{4}$ & 2,61 & 5,25 & 12,02 \\
$10^{3}$ & 7,09 & 13,49 & 11,85 \\
$10^{2}$ & 13,61 & 10,31 & 2,25 \\
$10^{1}$ & 0,18 & 3,05 & 0,75 \\
$10^{0}$ & 12,39 & 3,78 & 0,29 \\
$10^{-1}$ & 10,90 & 10,68 & 2,71 \\
$10^{-2}$ & 15,59 & 8,05 & 4,15 \\
$10^{-3}$ & 13,91 & 8,62 & 0,86 \\
$10^{-4}$ & 3,17 & 15,36 & 0,38 \\
$10^{-5}$ & 14,27 & 9,57 & 2,14 \\
$10^{-6}$ & 2,24 & 5,92 & 0,29 \\
$10^{-7}$ & 2,00 & 12,43 & 0,82 \\
$10^{-8}$ & 2,40 & 25,43 & 3,13 \\
$10^{-9}$ & 7,43 & 6,69 & 0,97 \\
$10^{-10}$ & 3,97 & 5,91 & 1,79 \\
Média & 7,19 & 9,23 & 2,96 \\
Desvio padrão & 5,19 & 5,56 & 3,89 \\
\hline
\end{tabular}

${ }^{*}$ foi preparada suspensão de colônias com turvação correspondente ao tubo 0,5 da escala de Mc Farland $\left(10^{8}\right.$ bactérias $\left./ \mathrm{mL}\right)$ e a partir desta foram feitas diluições de razão 10.

A comparação das médias de DNA extraído mostrou que o protocolo de Boom apresentou um resultado inferior que o PK $(p<0,05)$ e que o GT $(p<0,01)$.

Os gráficos 1, 2 e 3 mostram que não houve associação entre a concentração de DNA $(\mu \mathrm{g} / \mathrm{mL})$ obtida na extração e a concentração de bactérias $/ \mathrm{mL}$ para os três protocolos estudados. 


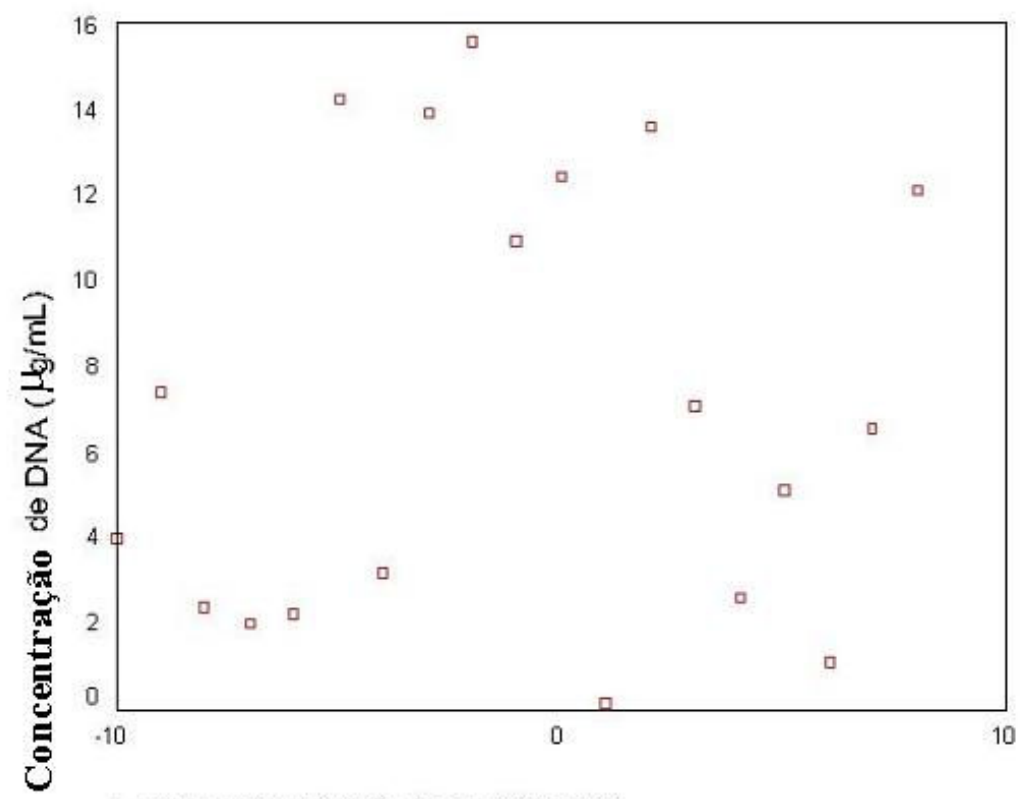

Log da concentração de bactérias $/ \mathrm{mL}$

Gráfico 1 - Correlação entre a concentração de Brucella abortus $/ \mathrm{mL}$ e a concentração de DNA $(\mu \mathrm{g} / \mathrm{mL})$ extraída pelo protocolo PK - São Paulo - 2008

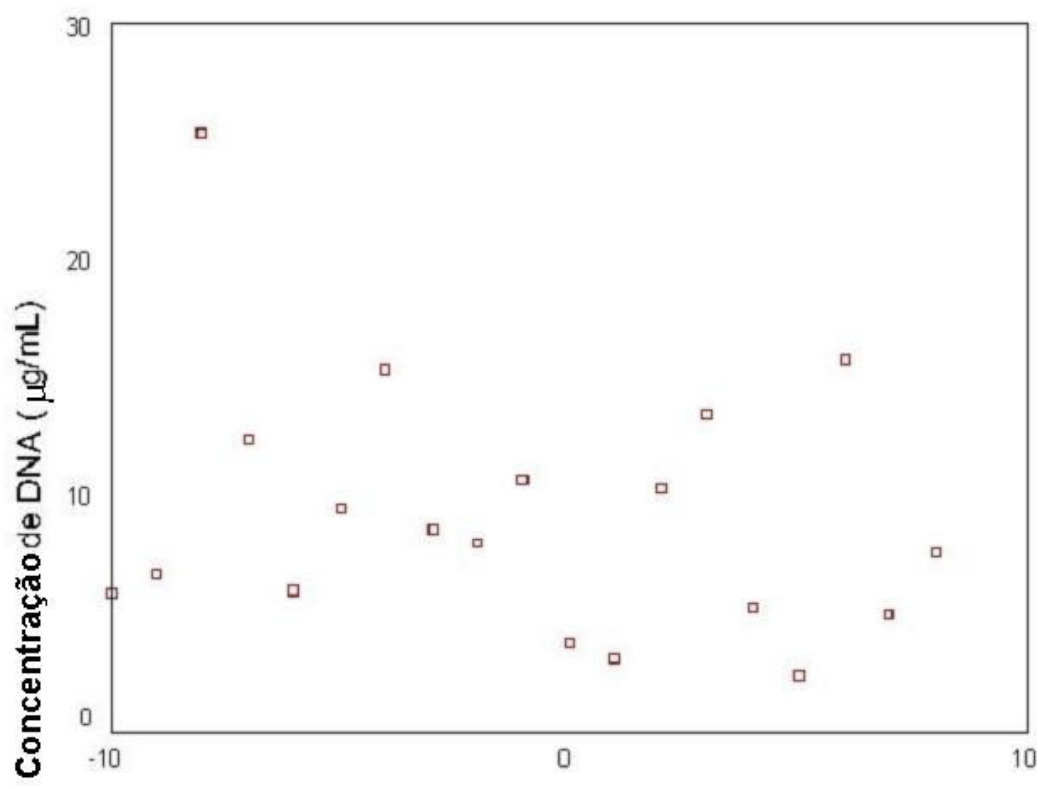

Log da concentração de bactérias $/ \mathrm{mL}$

Gráfico 2 - Correlação entre a concentração de Brucella abortus $/ \mathrm{mL}$ e a concentração de DNA $(\mu \mathrm{g} / \mathrm{mL})$ extraída pelo protocolo GT - São Paulo - 2008 


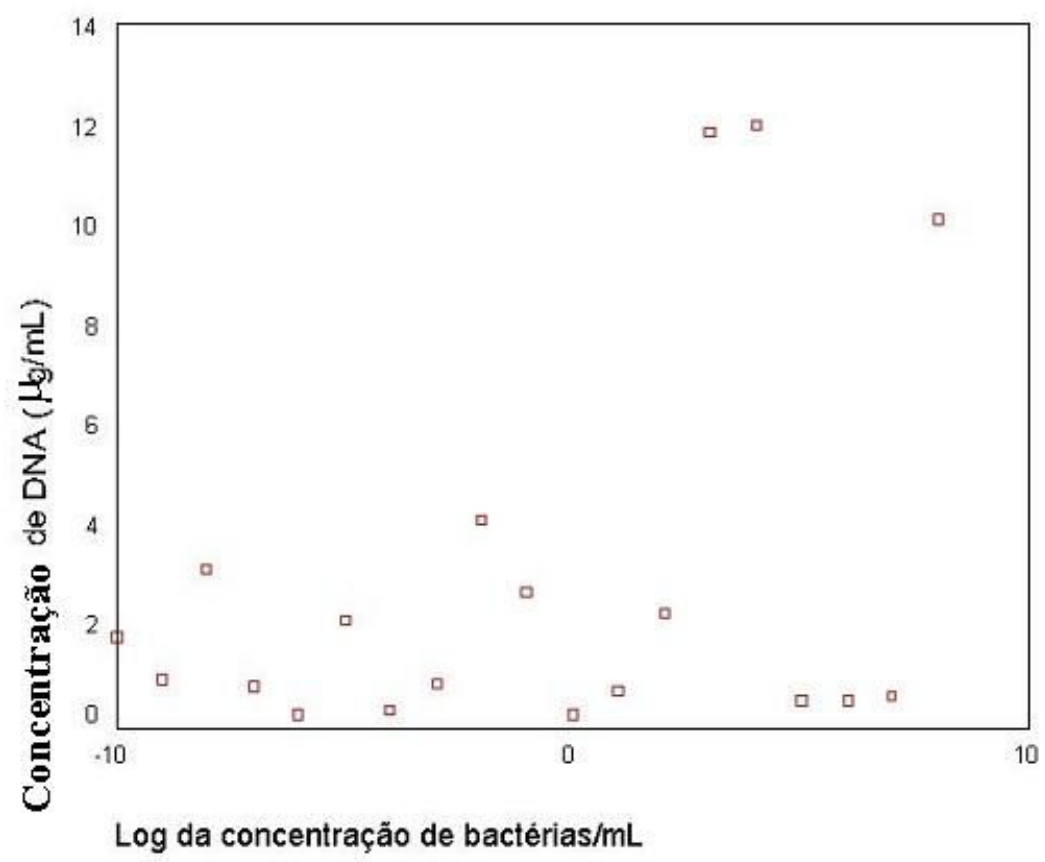

Gráfico 3 - Correlação entre a concentração de Brucella abortus $/ \mathrm{mL}$ e a concentração de DNA $(\mu \mathrm{g} / \mathrm{mL})$ extraída pelo protocolo do Boom - São Paulo - 2008

O gráfico 4 e a tabela 3 mostram que entre os três protocolos de extração de DNA não existiu correlação entre as concentrações de Brucella abortus ( $\mu \mathrm{g} / \mathrm{mL}$ ) obtidas. 


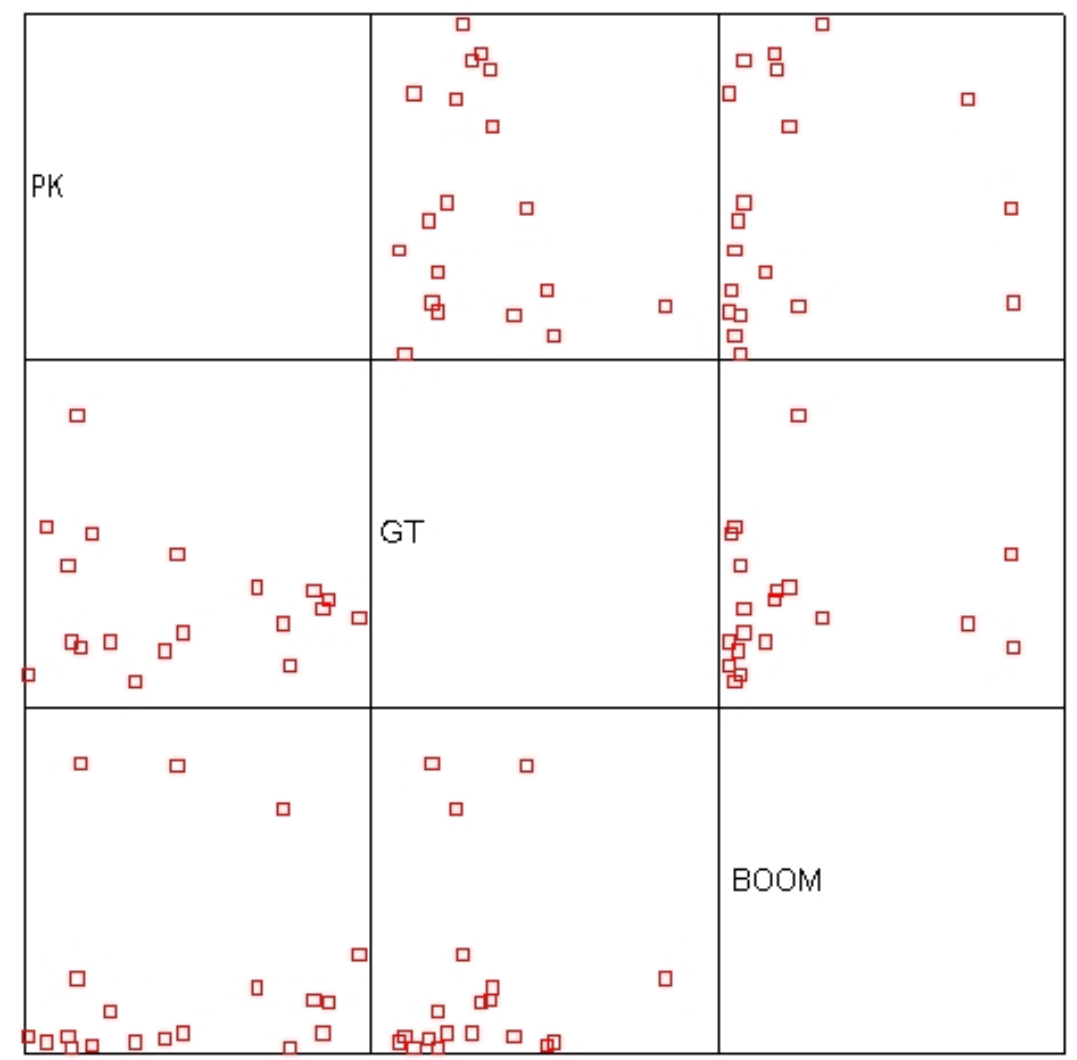

Gráfico 4 - Correlação entre as concentrações de DNA $(\mu \mathrm{g} / \mathrm{mL})$ verificadas por três protocolos de extração de DNA de Brucella abortus, São Paulo- 2008.

Tabela 3 - Coeficiente de correlação de Pearson referente à comparação das concentrações de DNA $(\mu \mathrm{g} / \mathrm{mL})$ obtidas por três protocolos de extração de DNA de Brucella abortus - São Paulo2008

\begin{tabular}{c|cc}
\hline & GT & Boom \\
\hline PK & $-0,175$ & 0,102 \\
GT & & 0,063 \\
\hline
\end{tabular}


Tabela 4- Razão entre as leituras de absorbância feitas com os comprimentos de onda 260 e 280 nM para três protocolos de extração de DNA, segundo diferentes concentrações de Brucella abortus - São Paulo - 2008

\begin{tabular}{c|ccc}
\hline $\begin{array}{c}\text { Número de } \\
\text { bactérias } / \mathrm{mL}\end{array}$ & PK & $\begin{array}{c}\text { Protocolos de extração de DNA } \\
\text { GT }\end{array}$ & BOOM \\
\hline $10^{8}$ & 1,18 & 1,74 & 1,11 \\
$10^{7}$ & 1,08 & 1,62 & 1,23 \\
$10^{6}$ & 1,09 & 1,59 & 1,15 \\
$10^{5}$ & 1,17 & 1,48 & 0,98 \\
$10^{4}$ & 1,86 & 1,27 & 1,10 \\
$10^{3}$ & 1,42 & 1,84 & 1,10 \\
$10^{2}$ & 1,21 & 1,69 & 1,00 \\
$10^{1}$ & 1,19 & 1,23 & 0,87 \\
$10^{0}$ & 1,13 & 1,46 & 1,11 \\
$10^{-1}$ & 1,13 & 1,69 & 1,02 \\
$10^{-2}$ & 1,15 & 1,15 & 0,94 \\
$10^{-3}$ & 1,13 & 1,38 & 0,76 \\
$10^{-4}$ & 1,23 & 1,78 & 0,73 \\
$10^{-5}$ & 1,16 & 1,20 & 1,22 \\
$10^{-6}$ & 1,90 & 1,50 & 0,68 \\
$10^{-7}$ & 1,68 & 1,70 & 1,05 \\
$10^{-8}$ & 1,65 & 1,66 & 1,12 \\
$10^{-9}$ & 1,19 & 1,36 & 1,06 \\
$10^{-10}$ & 1,38 & 1,40 & 1,13 \\
Média & 1,31 & 1,51 & 1,02 \\
Desvio padrão & 0,26 & 0,21 & 0,01 \\
\hline
\end{tabular}

As médias das razões de absorbância (Tabela 4) para os três protocolos de extração de DNA foram diferentes entre si $(p<0,001)$.

Nos gráficos 5, 6 e 7 pode ser observada a falta de associação entre a razão das absorbâncias (Tabela 4) obtidas por cada um dos protocolos de extração e a quantidade de bactérias $/ \mathrm{mL}$ presentes nas suspensões. 


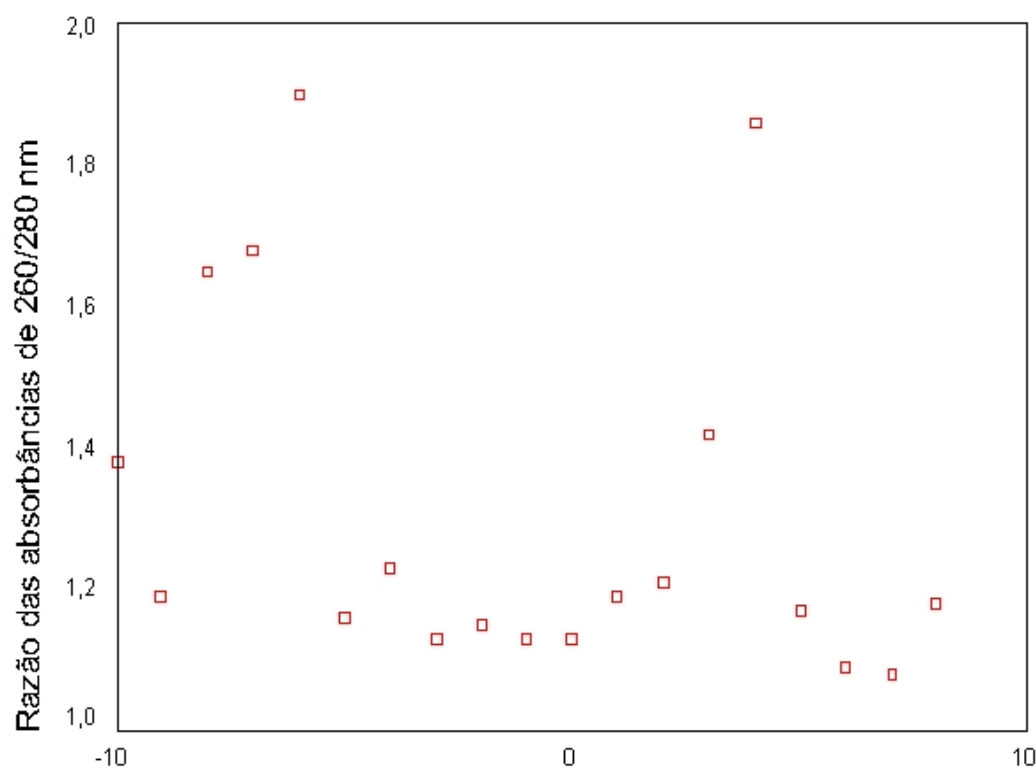

Log da concentração de bactérias $/ \mathrm{mL}$

Gráfico 5- Correlação entre as razões das leituras de absorbância feitas com os comprimentos de onda 260 e $280 \mathrm{nM}$ para o protocolo de extração $\mathrm{PK}$ e diferentes concentrações de Brucella abortus/mL - São Paulo - 2008.

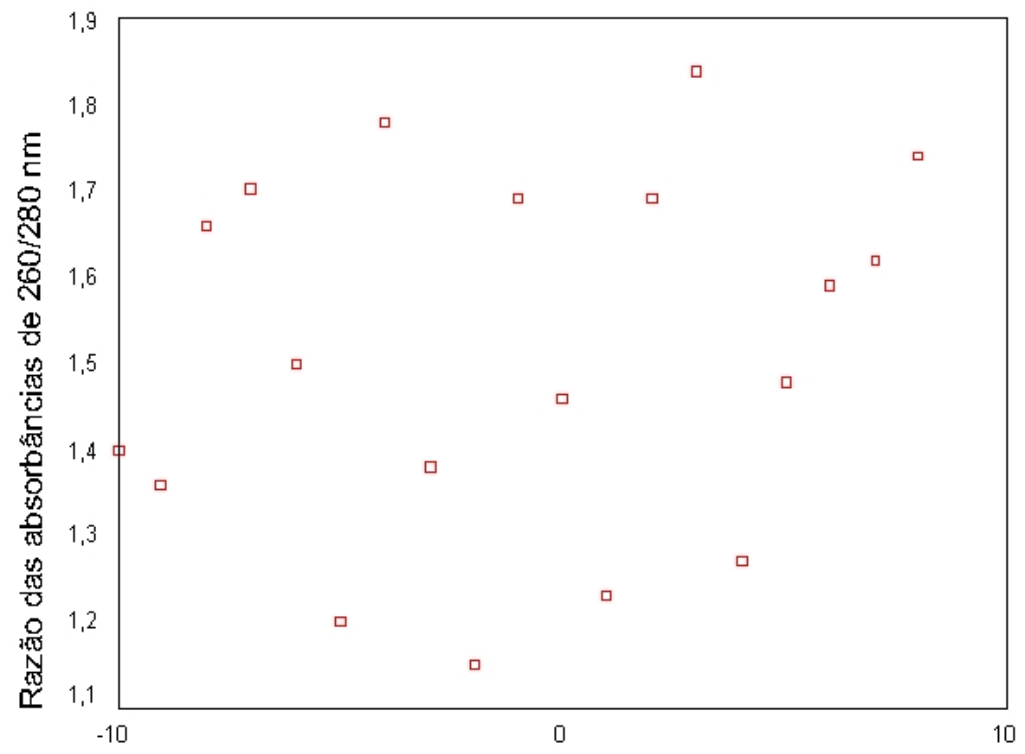

Log da concentração de bactérias $/ \mathrm{mL}$

Gráfico 6 - Correlação entre as razões das leituras de absorbância feitas com os comprimentos de onda 260 e $280 \mathrm{nM}$ para o protocolo de extração GT e diferentes concentrações de Brucella abortus/mL - São Paulo - 2008 


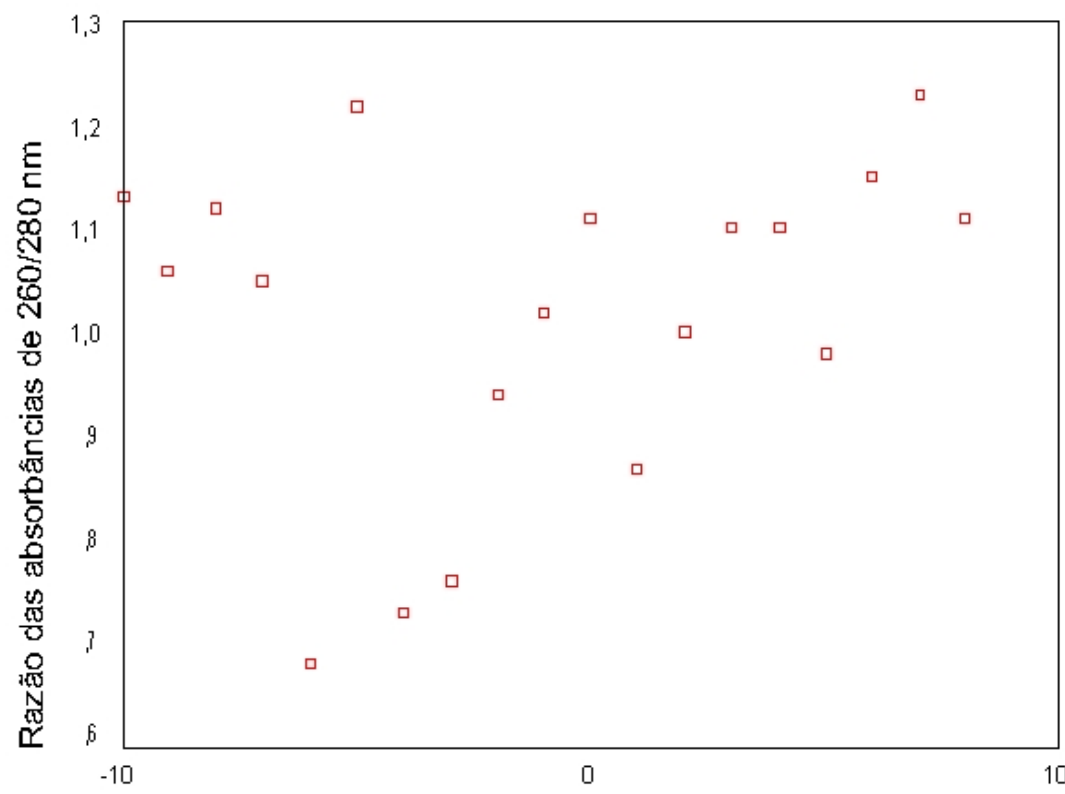

Log da concentração de bactérias $/ \mathrm{mL}$

Gráfico 7 - Correlação entre as razões das leituras de absorbância feitas com os comprimentos de onda 260 e $280 \mathrm{nM}$ para o protocolo de extração do Boom e diferentes concentrações de Brucella abortus/mL - São Paulo - 2008

O gráfico 8 e a tabela 5 demonstram que não existiu nenhuma associação entre os três protocolos de extração de DNA em relação à razão das absorbâncias referidas na tabela 4. 


\begin{tabular}{|c|c|c|c|c|c|c|c|}
\hline PK & & & & 口प & 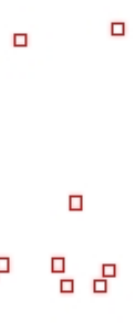 & $\begin{array}{c}\text { व } \\
\text { व } \\
\text { 口व } \\
\text { 口व }\end{array}$ & 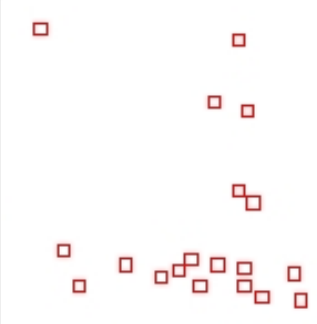 \\
\hline 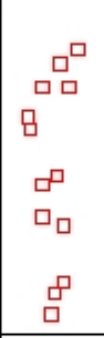 & $\begin{array}{l}\square \\
\square\end{array}$ & 品 & 口 & GT & & & 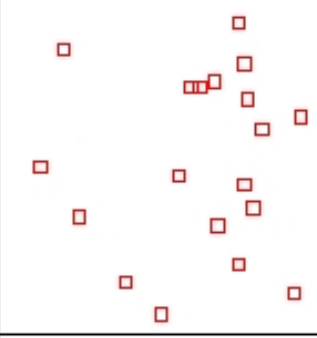 \\
\hline 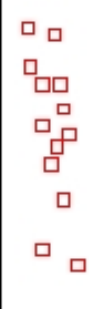 & ४ & $\begin{array}{l}\square \\
\square\end{array}$ & 口 & & 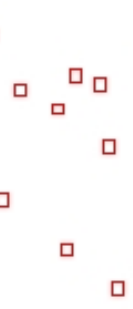 & 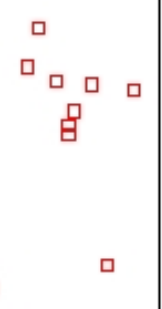 & BOOM \\
\hline
\end{tabular}

\section{Gráfico 8- Correlação entre as razões das leituras de absorbância feitas com os comprimentos de onda 260 e $280 \mathrm{nM}$ verificadas por três protocolos de extração de DNA de Brucella abortus - São Paulo- 2008}

Tabela 5 - Coeficiente de correlação de Pearson resultante da comparação das razões das leituras de absorbância feitas com os comprimentos de onda 260 e $280 \mathrm{nM}$ entre os três protocolo de extração de DNA de Brucella abortus - São Paulo - 2008

\begin{tabular}{c|cc}
\hline & GT & Boom \\
\hline PK & 0,06 & $-0,168$ \\
GT & & 0,041 \\
\hline
\end{tabular}

\subsection{COMPARAÇÃO DOS MÉTODOS DE EXTRAÇÃO DE DNA}

\subsubsection{Admitindo como gold standard o isolamento}

Resultados comparativos entre o isolamento clássico e a PCR com três diferentes protocolos de extração de DNA para a detecção de $B$. abortus, em amostras de pulmão de fetos abortados bovinos, podem ser observados na tabela 6 . 
Tabela 6 - Resultados da detecção de Brucella abortus pelo isolamento clássico e pela PCR realizada com três diferentes protocolos de extração de DNA em amostras de pulmão de fetos bovinos abortados - São Paulo - 2008

\begin{tabular}{|c|c|c|c|c|}
\hline \multirow{2}{*}{$\begin{array}{l}\text { Amostras } \\
\text { Pulmão }\end{array}$} & \multirow{2}{*}{$\begin{array}{c}\text { Isolamento } \\
\text { Brucella abortus }\end{array}$} & \multicolumn{3}{|c|}{ Protocolos de extração de DNA } \\
\hline & & PK & GT & BOOM \\
\hline B08 & - & - & - & - \\
\hline B09 & - & - & - & + \\
\hline B10 & - & + & - & + \\
\hline B11 & + & + & + & + \\
\hline B13 & - & + & - & + \\
\hline B14 & - & - & - & + \\
\hline $\mathrm{B} 20$ & + & + & + & + \\
\hline B22 & - & - & - & - \\
\hline B27 & + & + & + & + \\
\hline B28 & - & - & - & - \\
\hline B32 & + & + & + & + \\
\hline B41 & - & - & + & + \\
\hline B43 & - & - & - & - \\
\hline B48 & - & - & - & + \\
\hline B54 & + & + & + & + \\
\hline B55 & + & + & + & + \\
\hline B63 & + & + & + & + \\
\hline B65 & - & - & - & - \\
\hline B67 & - & - & - & + \\
\hline B69 & + & + & + & + \\
\hline B74 & + & + & + & + \\
\hline B80 & + & + & + & + \\
\hline B85 & + & + & - & + \\
\hline B88 & + & + & + & + \\
\hline B92 & + & + & + & + \\
\hline B99 & + & + & + & + \\
\hline B100 & + & + & + & + \\
\hline B205 & - & + & + & + \\
\hline B208 & + & + & - & + \\
\hline B216 & - & - & - & + \\
\hline B217 & - & + & - & + \\
\hline B234 & + & + & - & - \\
\hline
\end{tabular}


Tabela 7- Razão entre as leituras de absorbância feitas com os comprimentos de onda 260 e 280 nM para três protocolos de extração de DNA, segundo amostras de pulmão de fetos abortados bovinos - São Paulo - 2008.

\begin{tabular}{|c|c|c|c|}
\hline \multirow{2}{*}{$\begin{array}{l}\text { Amostras } \\
\text { Pulmão }\end{array}$} & \multicolumn{3}{|c|}{ Protocolos de extração de DNA } \\
\hline & PK & $\mathrm{GT}$ & BOOM \\
\hline B08 & 1,27 & 1,94 & 1,11 \\
\hline B09 & 1,46 & 1,91 & 1,10 \\
\hline B10 & 1,74 & 1,98 & 1,25 \\
\hline B11 & 1,68 & 1,91 & 1,13 \\
\hline B13 & 1,28 & 1,89 & 1,15 \\
\hline B14 & 1,90 & 1,45 & 1,20 \\
\hline B20 & 1,28 & 1,90 & 1,19 \\
\hline B22 & 1,43 & 1,92 & 1,37 \\
\hline B27 & 1,73 & 1,90 & 1,22 \\
\hline B28 & 1,82 & 1,95 & 1,28 \\
\hline B32 & 1,67 & 1,88 & 1,22 \\
\hline B41 & 1,82 & 1,95 & 1,18 \\
\hline B43 & 1,44 & 1,87 & 1,21 \\
\hline B48 & 1,45 & 1,98 & 1,21 \\
\hline B54 & 1,21 & 1,93 & 1,18 \\
\hline B55 & 1,76 & 1,93 & 1,19 \\
\hline B63 & 1,55 & 1,85 & 1,24 \\
\hline B65 & 1,80 & 1,93 & 1,25 \\
\hline B67 & 1,61 & 1,78 & 1,16 \\
\hline B69 & 1,79 & 1,89 & 1,22 \\
\hline B74 & 1,55 & 1,90 & 1,19 \\
\hline B80 & 1,85 & 1,92 & 1,19 \\
\hline B85 & 1,80 & 1,92 & 1,09 \\
\hline B88 & 1,85 & 1,93 & 1,51 \\
\hline B92 & 1,83 & 1,89 & 1,18 \\
\hline B99 & 1,84 & 1,90 & 1,19 \\
\hline B100 & 1,79 & 1,94 & 1,20 \\
\hline B205 & 1,61 & 1,88 & 1,16 \\
\hline B208 & 1,82 & 1,92 & 1,18 \\
\hline B216 & 1,73 & 1,93 & 1,18 \\
\hline B217 & 1,81 & 1,89 & 1,17 \\
\hline B234 & 1,54 & 1,92 & 1,18 \\
\hline Média & 1,65 & 1,90 & 1,20 \\
\hline Desvio Padrão & 0,20 & 0,09 & 0,08 \\
\hline
\end{tabular}

Para pulmões de fetos abortados de bovinos, as médias das razões de absorbância (Tabela 7) para os três protocolos de extração de DNA foram diferentes entre si $(p<0,001)$. 
O gráfico 9 e a tabela 8 demonstram que para pulmões de fetos abortados de bovinos não houve associação entre os três protocolos de extração de DNA em relação à razão das absorbâncias (Tabela 7).

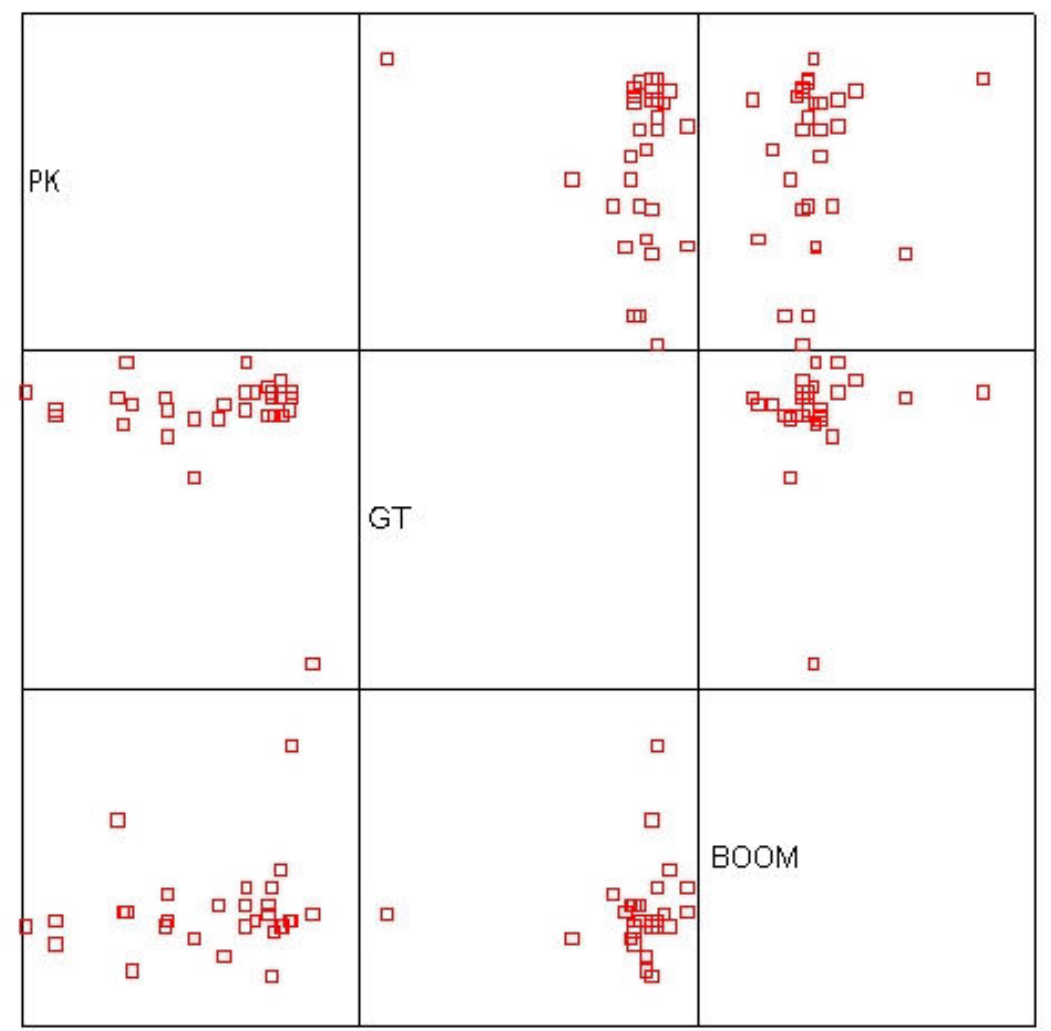

Gráfico 9- Correlação entre as razões das leituras de absorbância feitas com os comprimentos de onda 260 e $280 \mathrm{nM}$ para três diferentes protocolos de extração de DNA de Brucella abortus em pulmão de fetos abortados de bovinos - São Paulo - 2008

Tabela 8 - Coeficiente de correlação de Pearson entre as razões das leituras de absorbância feitas com os comprimentos de onda 260 e $280 \mathrm{nM}$ para três diferentes protocolos de extração de DNA de Brucella abortus em pulmão de fetos abortados de bovinos - São Paulo - 2008

\begin{tabular}{c|cc}
\hline & GT & Boom \\
\hline PK & $-0,146$ & 0,139 \\
GT & & 0,097 \\
\hline
\end{tabular}


Tabela 9- $\quad$ Concentrações de DNA ( $\mu \mathrm{g} / \mathrm{mL})$ obtidas por três diferentes protocolos de extração aplicados em amostras de pulmão de fetos bovinos abortados - São Paulo - 2008.

\begin{tabular}{|c|c|c|c|}
\hline \multirow{2}{*}{$\begin{array}{l}\text { Amostras } \\
\text { Pulmão }\end{array}$} & \multicolumn{3}{|c|}{ Protocolos de extração de DNA } \\
\hline & PK & GT & BOOM \\
\hline B08 & 41,83 & 99,07 & 15,69 \\
\hline B09 & 68,73 & 166,12 & 12,69 \\
\hline B10 & 44,57 & 68,72 & 12,91 \\
\hline B11 & 37,10 & 407,37 & 16,68 \\
\hline B13 & 41,07 & 56,13 & 13,03 \\
\hline B14 & 58,07 & 280,45 & 11,70 \\
\hline B20 & 1,64 & 332,81 & 15,18 \\
\hline B22 & 57,41 & 163,99 & 16,29 \\
\hline B27 & 223,11 & 623,41 & 15,29 \\
\hline B28 & 182,68 & 515,15 & 10,83 \\
\hline B32 & 155,17 & 212,11 & 14,27 \\
\hline B41 & 84,71 & 907,99 & 16,83 \\
\hline B43 & 59,94 & 193,93 & 15,07 \\
\hline B48 & 65,22 & 122,86 & 12,26 \\
\hline B54 & 3,13 & 329,35 & 8,74 \\
\hline B55 & 50,44 & 477,08 & 13,42 \\
\hline $\mathrm{B} 63$ & 99,17 & 129,26 & 13,52 \\
\hline B65 & 74,70 & 321,30 & 10,28 \\
\hline $\mathrm{B} 67$ & 20,97 & 129,12 & 11,65 \\
\hline B69 & 62,14 & 255,09 & 15,22 \\
\hline B74 & 80,10 & 144,99 & 11,60 \\
\hline $\mathrm{B} 80$ & 149,27 & 307,82 & 13,79 \\
\hline B85 & 49,50 & 312,09 & 0,40 \\
\hline B88 & 53,21 & 99,60 & 0,26 \\
\hline B92 & 94,20 & 259,02 & 14,53 \\
\hline B99 & 87,58 & 250,47 & 14,18 \\
\hline B100 & 105,97 & 783,33 & 13,42 \\
\hline B205 & 19,46 & 141,22 & 10,56 \\
\hline B208 & 57,02 & 574,03 & 16,61 \\
\hline B216 & 58,68 & 107,76 & 12,80 \\
\hline B217 & 47,68 & 197,15 & 10,79 \\
\hline B234 & 90,10 & 381,79 & 9,83 \\
\hline & 72,64 & 292,21 & 12,51 \\
\hline \multicolumn{4}{|l|}{ Desvio Padrão } \\
\hline & 48,55 & 206,46 & 3,83 \\
\hline
\end{tabular}


Para pulmões de fetos abortados de bovinos, a média das concentrações de DNA extraído pelo protocolo GT foi maior que aquelas obtidas pelos protocolos PK e Boom $(p<0,001$, Tabela 9).

O gráfico 10 e a tabela 10 mostram que para pulmões de fetos abortados de bovinos não existiu correlação entre as concentrações de DNA ( $\mu \mathrm{g} / \mathrm{mL})$ obtidas pelos três protocolos de extração.

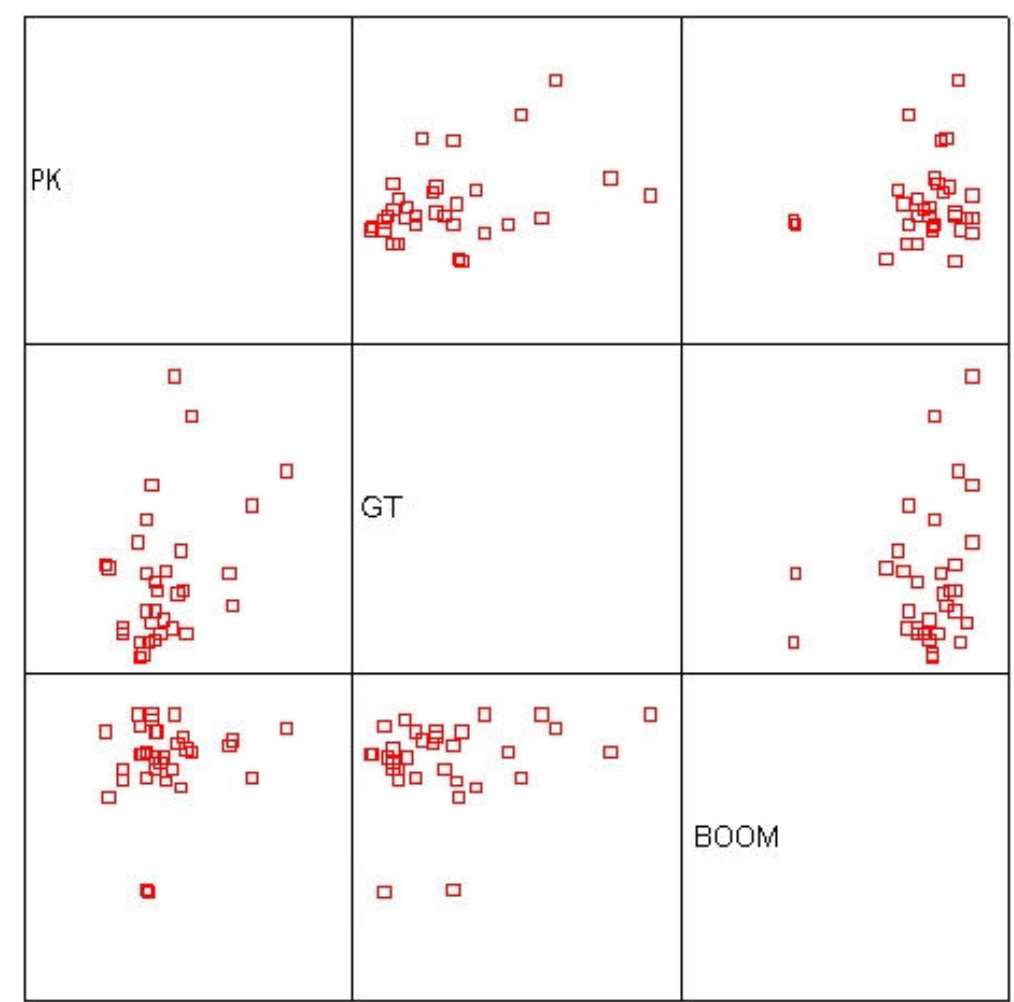

Gráfico 10 - Correlação entre as concentrações de DNA de Brucella abortus $(\mu \mathrm{g} / \mathrm{mL})$ obtidas por três protocolos de extração de amostras de pulmão de feto abortado de bovino - São Paulo - 2008

Tabela 10 - Coeficiente de correlação de Pearson entre as concentrações de DNA de Brucella abortus $(\mu \mathrm{g} / \mathrm{mL})$ obtidas por os três protocolos de extração em de pulmão de feto abortado de bovino - São Paulo - 2008

\begin{tabular}{l|cc}
\hline & GT & Boom \\
\hline PK & 0,384 & 0,158 \\
GT & & 0,239 \\
\hline
\end{tabular}


Resultados comparativos entre o isolamento clássico e a PCR com três diferentes protocolos de extração de DNA para a detecção de $B$. abortus, em amostras de baço de fetos abortados bovinos, podem ser observados na tabela 11.

Tabela 11 - Resultados da detecção de Brucella abortus pelo isolamento clássico e pela PCR realizada com três diferentes protocolos de extração de DNA em amostras de baço de fetos bovinos abortados - São Paulo - 2008

\begin{tabular}{|c|c|c|c|c|}
\hline \multirow{2}{*}{$\begin{array}{c}\text { Amostras } \\
\text { Baço }\end{array}$} & \multirow{2}{*}{$\begin{array}{c}\text { Isolamento } \\
\text { Brucella abortus }\end{array}$} & \multicolumn{3}{|c|}{ Protocolos de extração de DNA } \\
\hline & & PK & GT & BOOM \\
\hline B08 & - & - & - & + \\
\hline B09 & - & - & - & - \\
\hline B10 & - & - & - & - \\
\hline B13 & - & - & - & + \\
\hline B14 & - & - & - & - \\
\hline B20 & + & + & + & + \\
\hline B22 & - & - & - & + \\
\hline B28 & - & - & - & + \\
\hline B32 & + & + & + & + \\
\hline B41 & - & - & - & + \\
\hline B43 & - & - & - & - \\
\hline B48 & - & - & - & + \\
\hline B49 & + & + & + & + \\
\hline B54 & + & + & + & + \\
\hline B63 & + & + & + & + \\
\hline B65 & - & - & - & - \\
\hline B67 & - & - & - & + \\
\hline B74 & + & + & + & + \\
\hline B80 & + & + & + & + \\
\hline B88 & + & + & + & + \\
\hline B100 & + & + & + & + \\
\hline B104 & + & + & + & + \\
\hline B205 & - & - & - & + \\
\hline B216 & - & - & - & + \\
\hline B217 & - & - & - & + \\
\hline B234 & + & + & + & + \\
\hline
\end{tabular}


Tabela 12 - Razão entre as leituras de absorbância feitas com os comprimentos de onda 260 e 280 nM para três protocolos de extração de DNA, segundo amostras de baço de fetos abortados bovinos - São Paulo - 2008

\begin{tabular}{c|ccc}
\hline $\begin{array}{c}\text { Amostras } \\
\text { Baço }\end{array}$ & PK & $\begin{array}{c}\text { Protocolos de extração de DNA } \\
\text { GT }\end{array}$ & BOOM \\
\hline B08 & 1,64 & 1,96 & 0,83 \\
B09 & 1,77 & 1,88 & 1,12 \\
B10 & 1,90 & 1,82 & 1,18 \\
B13 & 1,73 & 1,94 & 1,19 \\
B14 & 1,65 & 1,97 & 1,14 \\
B20 & 1,79 & 1,90 & 1,18 \\
B22 & 1,65 & 1,93 & 1,15 \\
B28 & 1,84 & 1,95 & 1,19 \\
B32 & 1,46 & 1,92 & 1,28 \\
B41 & 1,82 & 1,91 & 1,23 \\
B43 & 1,75 & 1,95 & 1,18 \\
B48 & 1,85 & 1,96 & 1,23 \\
B49 & 1,66 & 1,92 & 1,15 \\
B54 & 1,28 & 1,89 & 1,18 \\
B63 & 1,74 & 1,98 & 1,11 \\
B65 & 1,77 & 1,91 & 1,12 \\
B67 & 1,89 & 1,91 & 1,17 \\
B74 & 1,71 & 1,92 & 1,14 \\
B80 & 1,79 & 1,92 & 1,27 \\
B88 & 1,90 & 1,98 & 1,39 \\
B100 & 1,80 & 1,91 & 1,17 \\
B104 & 1,77 & 1,91 & 1,12 \\
B205 & 1,83 & 1,91 & 1,16 \\
B216 & 1,86 & 1,88 & 1,21 \\
B217 & 1,80 & 1,93 & 1,17 \\
B234 & 1,68 & 1,95 & 0,09 \\
Média & 1,74 & 1,92 & \\
Desvio Padrão & & & \\
\hline
\end{tabular}

Para baços de fetos abortados de bovinos, as médias das razões de absorbância (Tabela 12) para os três protocolos de extração de DNA foram diferentes entre si $(p<0,001)$.

O gráfico 11 e a tabela 13 demonstram que para baços de fetos abortados de bovinos não houve associação entre os três protocolos de extração de DNA em relação à razão das absorbâncias (Tabela 12). 


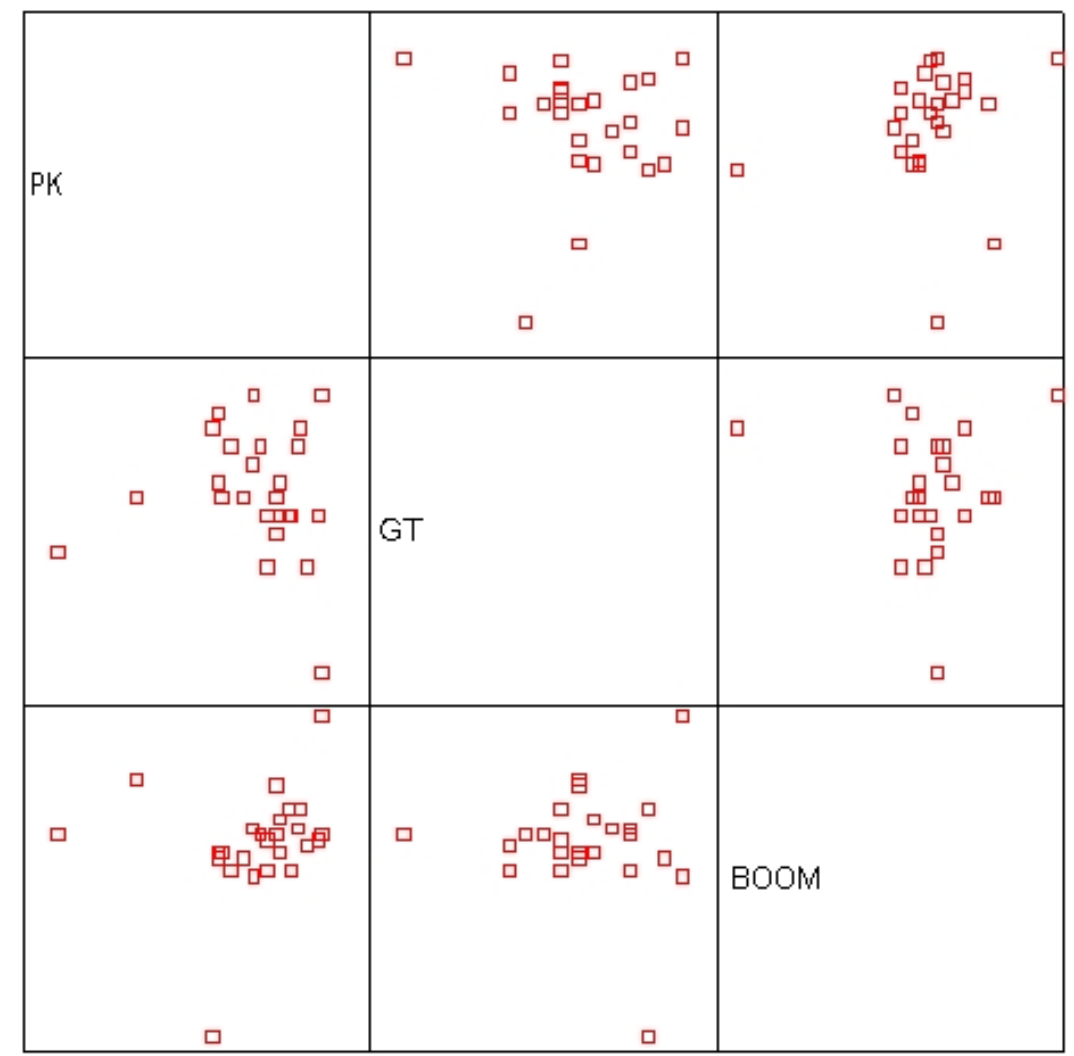

Gráfico 11 - Correlação entre as razões das leituras de absorbância feitas com os comprimentos de onda 260 e $280 \mathrm{nM}$ para três diferentes protocolos de extração de DNA de Brucella abortus em baço de fetos abortados de bovinos - São Paulo - 2008

Tabela 13 - Coeficiente de correlação de Pearson entre as razões das leituras de absorbância feitas com os comprimentos de onda 260 e $280 \mathrm{nM}$ para três diferentes protocolos de extração de DNA de Brucella abortus em baço de fetos abortados de bovinos - São Paulo - 2008

\begin{tabular}{c|cc}
\hline & GT & Boom \\
\hline PK & $-0,062$ & 0,181 \\
GT & & $-0,017$ \\
\hline
\end{tabular}


Tabela 14 - Concentrações de DNA ( $\mu \mathrm{g} / \mathrm{mL})$ obtidas por três diferentes protocolos de extração aplicados em amostras de baço de fetos bovinos abortados - São Paulo - 2008

\begin{tabular}{|c|c|c|c|}
\hline \multirow{2}{*}{$\begin{array}{c}\text { Amostras } \\
\text { Baço }\end{array}$} & \multicolumn{3}{|c|}{ Protocolos de extração de DNA } \\
\hline & PK & GT & BOOM \\
\hline B08 & 124,32 & 518,35 & 14,38 \\
\hline B09 & 235,41 & 1311,82 & 10,51 \\
\hline B10 & 509,35 & 1654,94 & 12,88 \\
\hline B13 & 179,61 & 550,37 & 16,77 \\
\hline B14 & 140,62 & 1351,63 & 12,32 \\
\hline B20 & 9,20 & 469,86 & 14,71 \\
\hline B22 & 110,84 & 792,23 & 14,06 \\
\hline B28 & 213,09 & 1162,98 & 12,69 \\
\hline B32 & 67,51 & 455,21 & 13,35 \\
\hline B41 & 155,28 & 278,57 & 12,47 \\
\hline B43 & 249,75 & 839,13 & 14,24 \\
\hline B48 & 403,86 & 939,67 & 14,03 \\
\hline B49 & 132,03 & 1290,09 & 12,52 \\
\hline B54 & 5,42 & 230,73 & 3,65 \\
\hline B63 & 15,35 & 289,60 & 22,34 \\
\hline B65 & 58,73 & 596,00 & 11,03 \\
\hline B67 & 243,10 & 1022,03 & 14,84 \\
\hline B74 & 172,91 & 1424,02 & 14,73 \\
\hline B80 & 42,33 & 468,29 & 14,68 \\
\hline B88 & 463,12 & 1636,05 & 0,77 \\
\hline B100 & 58,54 & 563,11 & 12,51 \\
\hline B104 & 45,84 & 704,59 & 13,88 \\
\hline B205 & 118,96 & 1080,89 & 12,20 \\
\hline B216 & 114,44 & 1246,20 & 15,99 \\
\hline B217 & 125,01 & 983,93 & 11,50 \\
\hline B234 & 170,50 & 978,96 & 12,57 \\
\hline Média & 160,20 & 878,43 & 12,91 \\
\hline Desvio & & & \\
\hline Padrão & 131,29 & 422,12 & 3,90 \\
\hline
\end{tabular}

Para baços de fetos abortados de bovinos, a média das concentrações de DNA extraído pelo protocolo GT foi maior que aquelas obtidas pelos protocolos PK e Boom $(p<0,001$, Tabela 14).

O gráfico 12 e a tabela 15 mostram que para baços de fetos abortados de bovinos existiu uma discreta correlação entre as concentrações de DNA $(\mu \mathrm{g} / \mathrm{mL})$ obtidas pelos três protocolos de extração. 


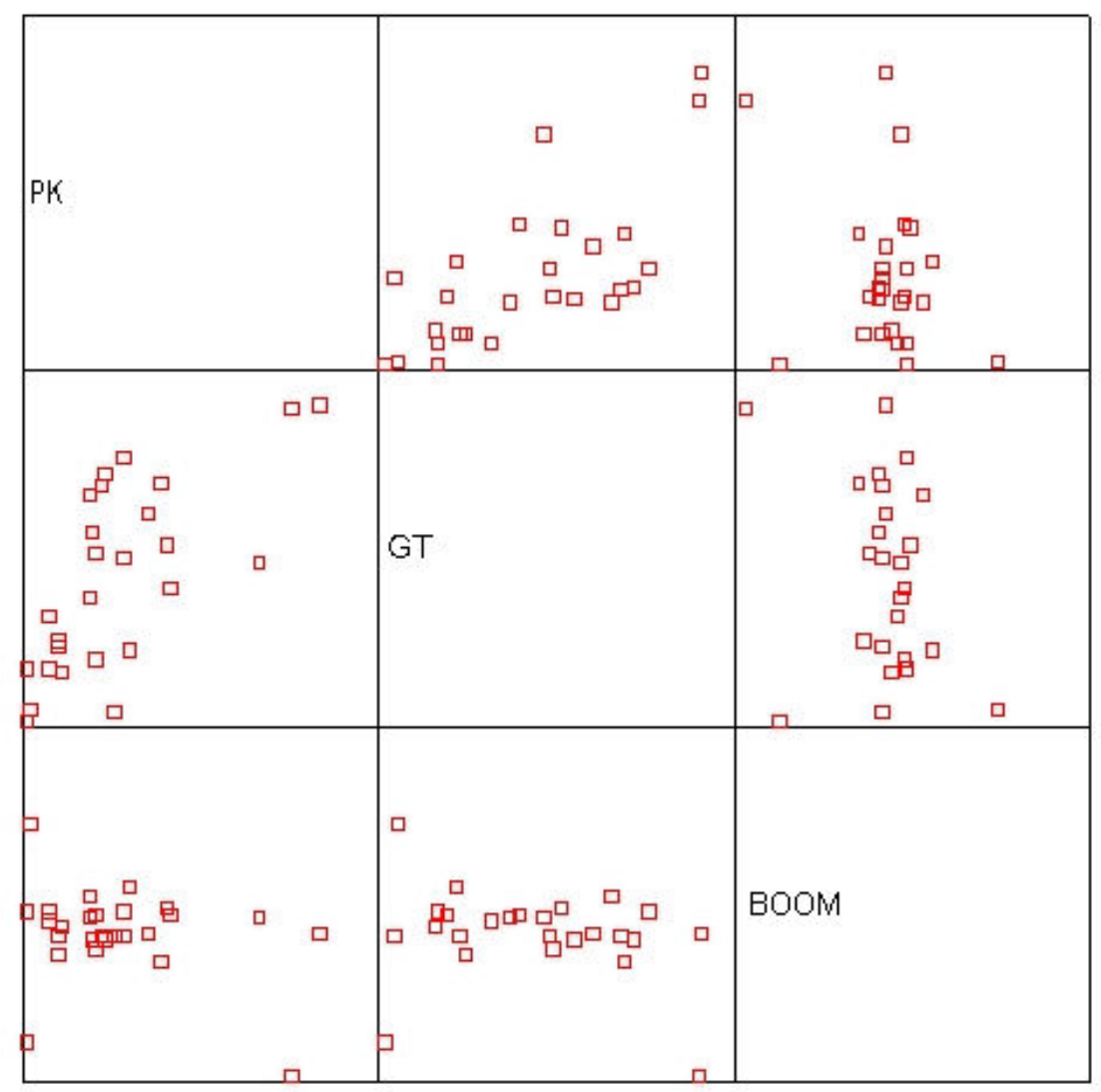

Gráfico 12 - Correlação entre as concentrações de DNA de Brucella abortus $(\mu \mathrm{g} / \mathrm{mL})$ obtidas por três protocolos de extração de amostras de baço de feto abortado de bovino - São Paulo - 2008

Tabela 15 - Coeficiente de correlação de Pearson entre as concentrações de DNA de Brucella abortus $(\mu \mathrm{g} / \mathrm{mL})$ obtidas por os três protocolos de extração em de baço de feto abortado de bovino - São Paulo - 2008

\begin{tabular}{c|cc}
\hline & GT & Boom \\
\hline PK & 0,692 & $-0,29$ \\
GT & & $-0,268$ \\
\hline
\end{tabular}


Resultados comparativos entre o isolamento clássico e a PCR com três diferentes protocolos de extração de DNA para a detecção de $B$. abortus, em amostras de fígado de fetos abortados bovinos, podem ser observados na tabela 16.

Tabela 16 Resultados da detecção de Brucella abortus pelo isolamento clássico e pela PCR realizada com três diferentes protocolos de extração de DNA em amostras de fígado de fetos bovinos abortados - São Paulo - 2008

\begin{tabular}{|c|c|c|c|c|}
\hline \multirow{2}{*}{$\begin{array}{l}\text { Amostras } \\
\text { Fígado }\end{array}$} & \multirow{2}{*}{$\begin{array}{c}\text { Isolamento } \\
\text { Brucella abortus }\end{array}$} & \multicolumn{3}{|c|}{ Protocolos de extração de DNA } \\
\hline & & PK & GT & BOOM \\
\hline B08 & - & - & - & + \\
\hline B09 & - & - & - & + \\
\hline B10 & - & - & - & + \\
\hline B13 & - & - & + & - \\
\hline B14 & - & - & - & - \\
\hline B22 & - & - & - & + \\
\hline B27 & + & + & + & + \\
\hline B28 & - & - & - & + \\
\hline B32 & + & + & + & + \\
\hline B34 & + & + & + & - \\
\hline B41 & - & - & + & + \\
\hline B43 & - & - & - & - \\
\hline B48 & - & - & - & + \\
\hline B54 & + & + & + & + \\
\hline B63 & + & + & + & + \\
\hline B65 & - & - & - & - \\
\hline B67 & - & - & + & + \\
\hline B88 & + & + & + & + \\
\hline B202 & + & + & - & -0 \\
\hline B205 & - & + & - & + \\
\hline B208 & + & + & + & - \\
\hline B216 & - & - & - & + \\
\hline B217 & - & - & - & - \\
\hline
\end{tabular}


Tabela 17- Razão entre as leituras de absorbância feitas com os comprimentos de onda 260 e $280 \mathrm{nM}$ para três protocolos de extração de DNA, segundo amostras de fígado de fetos abortados bovinos - São Paulo - 2008

\begin{tabular}{cccc}
\hline $\begin{array}{c}\text { Amostras } \\
\text { Fígado }\end{array}$ & PK & $\begin{array}{c}\text { Protocolos de extração de DNA } \\
\text { GT }\end{array}$ & BOOM \\
\hline B08 & 1,59 & 1,99 & 1,22 \\
B09 & 1,67 & 1,84 & 0,96 \\
B10 & 1,81 & 1,94 & 1,20 \\
B13 & 1,81 & 1,97 & 1,24 \\
B14 & 1,58 & 1,76 & 1,05 \\
B22 & 1,18 & 1,88 & 1,14 \\
B27 & 1,25 & 1,87 & 1,09 \\
B28 & 1,72 & 1,81 & 1,16 \\
B32 & 1,32 & 1,91 & 1,23 \\
B34 & 1,74 & 1,74 & 1,11 \\
B41 & 1,44 & 1,81 & 1,31 \\
B43 & 1,48 & 1,86 & 1,12 \\
B48 & 1,62 & 1,74 & 1,10 \\
B54 & 1,30 & 1,94 & 1,20 \\
B63 & 1,27 & 1,82 & 1,12 \\
B65 & 1,60 & 1,81 & 1,24 \\
B67 & 1,78 & 1,90 & 1,25 \\
B88 & 1,80 & 1,95 & 1,27 \\
B202 & 1,52 & 1,68 & 1,12 \\
B205 & 1,78 & 1,93 & 1,17 \\
B208 & 1,86 & 1,93 & 1,02 \\
B216 & 1,76 & 1,75 & 1,09 \\
B217 & 1,72 & 1,95 & 1,10 \\
Média & 1,59 & 1,86 & 1,15 \\
Desvio & & & 0,09 \\
Padrão & 0,21 & 0,09 & \\
\hline
\end{tabular}

Para fígados de fetos abortados de bovinos, as médias das razões de absorbância (Tabela 17) para os três protocolos de extração de DNA foram diferentes entre si $(\mathrm{p}<0,001)$.

O gráfico 13 e a tabela 18 demonstram que para fígados de fetos abortados de bovinos não houve associação entre os três protocolos de extração de DNA em relação à razão das absorbâncias (Tabela 17). 


\begin{tabular}{|c|c|c|c|c|}
\hline PK & ㅁ & $\begin{array}{l}0^{0} \\
{ }_{0}\end{array}$ & 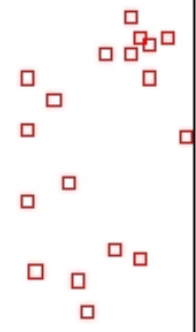 & 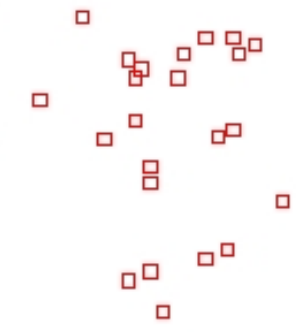 \\
\hline 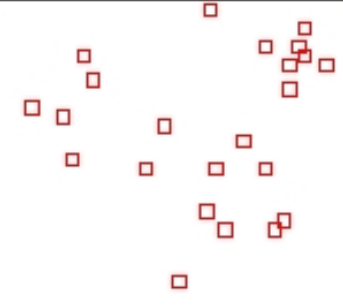 & GT & & & 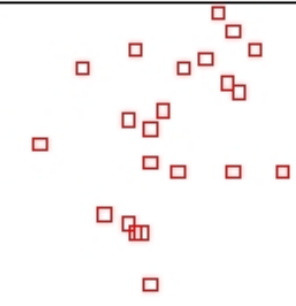 \\
\hline 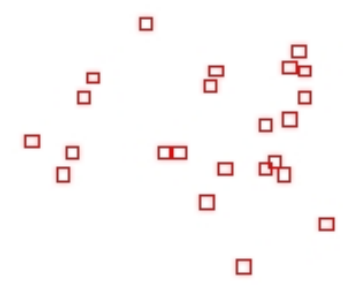 & ㅁ & $\begin{array}{c}\text { 用 } \\
\text { 口 }\end{array}$ & 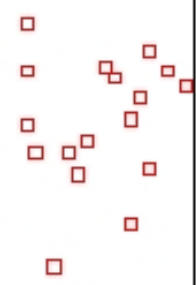 & $\mathrm{BOOM}$ \\
\hline
\end{tabular}

Gráfico 13 - Correlação entre as razões das leituras de absorbância feitas com os comprimentos de onda 260 e 280 nM para três diferentes protocolos de extração de DNA de Brucella abortus em fígado de fetos abortados de bovinos - São Paulo - 2008

Tabela 18 - Coeficiente de correlação de Pearson entre as razões das leituras de absorbância feitas com os comprimentos de onda 260 e $280 \mathrm{nM}$ para três diferentes protocolos de extração de DNA de Brucella abortus em fígado de fetos abortados de bovinos - São Paulo - 2008

\begin{tabular}{c|cc}
\hline & GT & Boom \\
\hline PK & 0,123 & $-0,033$ \\
GT & & 0,352 \\
\hline
\end{tabular}


Tabela 19 - Concentrações de DNA ( $\mu \mathrm{g} / \mathrm{mL})$ obtidas por três diferentes protocolos de extração aplicados em amostras de fígado de fetos bovinos abortados - São Paulo - 2008

\begin{tabular}{|c|c|c|c|}
\hline \multirow{2}{*}{$\begin{array}{c}\text { Amostras } \\
\text { Fígado }\end{array}$} & \multicolumn{3}{|c|}{ Protocolos de extração de DNA } \\
\hline & PK & GT & BOOM \\
\hline B08 & 102,30 & 676,90 & 15,73 \\
\hline B09 & 47,02 & 903,91 & 14,28 \\
\hline B10 & 139,04 & 1006,41 & 12,79 \\
\hline B13 & 331,24 & 816,61 & 13,88 \\
\hline B14 & 130,67 & 904,65 & 11,71 \\
\hline B22 & 28,08 & 921,46 & 15,75 \\
\hline B27 & 35,54 & 256,61 & 14,66 \\
\hline B28 & 67,10 & 669,43 & 14,91 \\
\hline B32 & 42,25 & 339,57 & 13,24 \\
\hline B34 & 79,46 & 205,85 & 14,16 \\
\hline B41 & 11,56 & 52,12 & 13,44 \\
\hline B43 & 81,78 & 538,91 & 14,23 \\
\hline B48 & 132,47 & 826,86 & 13,28 \\
\hline B54 & 4,26 & 585,72 & 2,99 \\
\hline B63 & 38,90 & 68,45 & 15,86 \\
\hline B65 & 63,23 & 1057,87 & 10,26 \\
\hline B67 & 67,56 & 674,53 & 11,01 \\
\hline B88 & 82,96 & 970,67 & 1,68 \\
\hline B202 & 44,66 & 925,30 & 13,68 \\
\hline B205 & 75,86 & 593,88 & 14,92 \\
\hline B208 & 159,00 & 1451,20 & 16,65 \\
\hline B216 & 66,07 & 683,52 & 14,44 \\
\hline B217 & 31,80 & 498,11 & 13,98 \\
\hline $\begin{array}{l}\text { Média } \\
\text { Desvio }\end{array}$ & 80,99 & 679,50 & 12,94 \\
\hline Padrão & 68,20 & 340,16 & 3,68 \\
\hline
\end{tabular}

Para fígados de fetos abortados de bovinos, a média das concentrações de DNA extraído pelo protocolo GT foi maior que aquelas obtidas pelos protocolos PK e Boom $(p<0,001$, Tabela 19).

O gráfico 14 e a tabela 20 mostram que para fígados de fetos abortados de bovinos não existiu correlação entre as concentrações de DNA $(\mu \mathrm{g} / \mathrm{mL})$ obtidas pelos três protocolos de extração. 


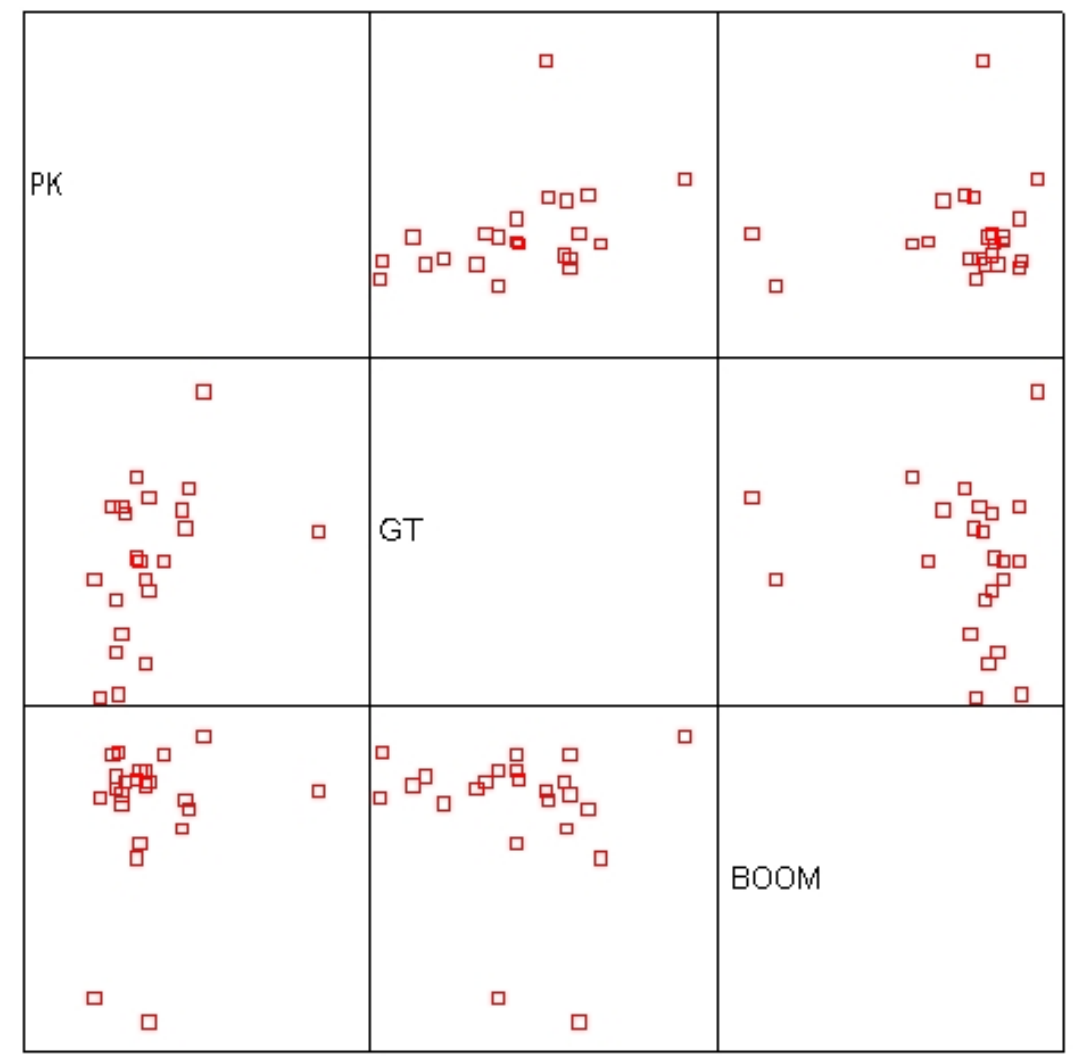

Gráfico 14- Correlação entre as concentrações de DNA de Brucella abortus ( $\mu \mathrm{g} / \mathrm{mL})$ obtidas por três protocolos de extração de amostras de fígado de feto abortado de bovino - São Paulo - 2008

Tabela 20 - Coeficiente de correlação de Pearson entre as concentrações de DNA de Brucella abortus $(\mu \mathrm{g} / \mathrm{mL})$ obtidas por os três protocolos de extração em de fígado de feto abortado de bovino - São Paulo - 2008

\begin{tabular}{l|cc}
\hline & GT & Boom \\
\hline PK & 0,423 & 0,139 \\
GT & & $-0,129$ \\
\hline
\end{tabular}


Resultados comparativos entre o isolamento clássico e a PCR com três diferentes protocolos de extração de DNA para a detecção de $B$. abortus, em amostras de linfonodo bronquial de fetos abortados bovinos, podem ser observados na tabela 21.

Tabela 21 - Resultados da detecção de Brucella abortus pelo isolamento clássico e pela PCR realizada com três diferentes protocolos de extração de DNA em amostras de linfonodo bronquial de fetos bovinos abortados - São Paulo - 2008

\begin{tabular}{|c|c|c|c|c|}
\hline \multirow{2}{*}{$\begin{array}{c}\text { Amostras } \\
\text { Linfonodo BR }\end{array}$} & \multirow{2}{*}{$\begin{array}{c}\text { Isolamento } \\
\text { Brucella abortus }\end{array}$} & \multicolumn{3}{|c|}{ Protocolos de extração de DNA } \\
\hline & & PK & GT & Boom \\
\hline B03 & + & - & - & + \\
\hline B08 & - & - & - & - \\
\hline B09 & - & - & - & - \\
\hline B10 & - & + & - & - \\
\hline B13 & - & + & - & - \\
\hline B14 & - & - & - & + \\
\hline B22 & - & - & - & - \\
\hline B27 & + & + & + & + \\
\hline B28 & - & + & - & - \\
\hline B41 & - & - & + & + \\
\hline B43 & - & - & - & - \\
\hline B48 & - & - & - & + \\
\hline B49 & + & + & + & + \\
\hline B54 & + & + & + & + \\
\hline B65 & - & - & - & + \\
\hline B67 & - & - & - & - \\
\hline B74 & + & + & + & + \\
\hline B88 & + & + & + & + \\
\hline B205 & - & - & - & + \\
\hline B216 & - & - & - & + \\
\hline B217 & - & - & + & + \\
\hline B235 & + & - & - & - \\
\hline
\end{tabular}


Tabela 22 - Razão entre as leituras de absorbância feitas com os comprimentos de onda 260 e 280 nM para três protocolos de extração de DNA, segundo amostras de linfonodo bronquial de fetos abortados bovinos - São Paulo - 2008

\begin{tabular}{cccc}
\hline $\begin{array}{c}\text { Amostras } \\
\text { Linfonodo BR }\end{array}$ & PK & Protocolos de extração de DNA & BOOM \\
\hline B03 & 1,72 & 1,88 & 1,16 \\
B08 & 1,33 & 1,96 & 1,13 \\
B09 & 1,25 & 1,91 & 1,18 \\
B10 & 1,70 & 1,93 & 1,20 \\
B13 & 1,43 & 1,91 & 1,26 \\
B14 & 1,81 & 1,94 & 1,25 \\
B22 & 1,24 & 1,86 & 1,16 \\
B27 & 1,49 & 1,86 & 1,28 \\
B28 & 1,83 & 1,97 & 1,34 \\
B41 & 1,50 & 1,80 & 1,08 \\
B43 & 1,69 & 1,91 & 1,23 \\
B48 & 1,64 & 1,98 & 1,17 \\
B49 & 1,39 & 1,90 & 1,26 \\
B54 & 1,28 & 1,86 & 1,81 \\
B65 & 1,71 & 1,89 & 1,18 \\
B67 & 1,53 & 1,78 & 1,09 \\
B74 & 1,36 & 1,88 & 1,19 \\
B88 & 1,67 & 1,93 & 1,46 \\
B205 & 1,79 & 1,92 & 1,21 \\
B216 & 1,89 & 1,93 & 1,25 \\
B217 & 1,58 & 1,91 & 1,19 \\
B235 & 1,84 & 1,92 & 1,21 \\
Média & 1,58 & 1,90 & 1,24 \\
Desvio Padrão & & & \\
\hline & 0,21 & 0,05 & \\
\hline
\end{tabular}

Para linfonodos bronquiais de fetos abortados de bovinos, as médias das razões de absorbância (Tabela 22) para os três protocolos de extração de DNA foram diferentes entre si $(p<0,001)$.

O gráfico 15 e a tabela 23 demonstram que para linfonodos bronquiais de fetos abortados de bovinos não houve associação entre os três protocolos de extração de DNA em relação à razão das absorbâncias (Tabela 22). 


\begin{tabular}{|c|c|c|c|c|c|}
\hline PK & ם & 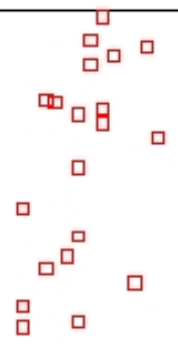 & 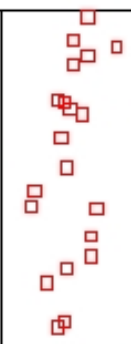 & 口 & 口 \\
\hline 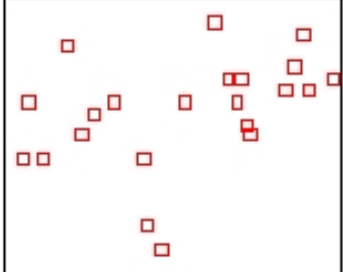 & GT & & 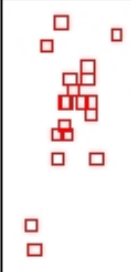 & 口 & 口 \\
\hline 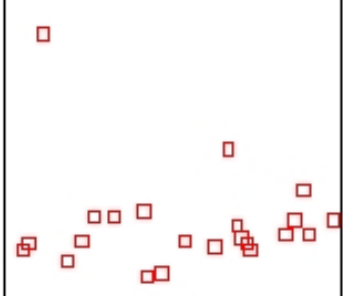 & 口ロ & 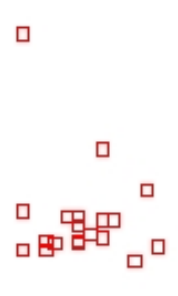 & $\mathrm{BOOM}$ & & \\
\hline
\end{tabular}

\section{Gráfico 15 - Correlação entre as razões das leituras de absorbância feitas com os comprimentos de onda 260 e $280 \mathrm{nM}$ para três diferentes protocolos de extração de DNA de Brucella abortus em linfonodo bronquial de fetos abortados de bovinos - São Paulo - 2008}

Tabela 23 - Coeficiente de correlação de Pearson entre as razões das leituras de absorbância feitas com os comprimentos de onda 260 e $280 \mathrm{nM}$ para três diferentes protocolos de extração de DNA de Brucella abortus em linfonodo bronquial de fetos abortados de bovinos - São Paulo - 2008

\begin{tabular}{c|cc}
\hline & GT & Boom \\
\hline PK & 0,382 & $-0,104$ \\
GT & & 0,094 \\
\hline
\end{tabular}


Tabela 24 - Concentrações de DNA $(\mu \mathrm{g} / \mathrm{mL})$ obtidas por três diferentes protocolos de extração aplicados em amostras de linfonodo bronquial de fetos bovinos abortados - São Paulo - 2008

\begin{tabular}{cccc}
\hline $\begin{array}{c}\text { Amostras } \\
\text { Linfonodo Br }\end{array}$ & PK & $\begin{array}{c}\text { Protocolos de extração de DNA } \\
\text { GT }\end{array}$ & BOOM \\
\hline B03 & 18,50 & 216,00 & 19,31 \\
B08 & 43,34 & 121,50 & 17,02 \\
B09 & 36,74 & 45,34 & 15,68 \\
B10 & 17,08 & 103,13 & 12,64 \\
B13 & 62,01 & 123,73 & 17,08 \\
B14 & 345,88 & 1116,10 & 12,93 \\
B22 & 32,38 & 108,69 & 13,90 \\
B27 & 70,37 & 216,70 & 13,62 \\
B28 & 60,18 & 652,58 & 12,60 \\
B41 & 17,92 & 36,72 & 13,14 \\
B43 & 145,19 & 492,33 & 15,50 \\
B48 & 158,85 & 369,42 & 12,85 \\
B49 & 52,32 & 97,90 & 10,11 \\
B54 & 3,17 & 52,68 & 1,19 \\
B65 & 19,87 & 280,78 & 15,79 \\
B67 & 89,90 & 23,91 & 13,03 \\
B74 & 45,38 & 157,94 & 14,36 \\
B88 & 28,42 & 60,66 & 4,47 \\
B205 & 60,56 & 302,34 & 11,70 \\
B216 & 401,70 & 545,02 & 16,09 \\
B217 & 18,24 & 351,31 & 15,62 \\
B235 & 132,92 & 796,40 & 17,53 \\
Média & 84,59 & 285,05 & 13,46 \\
Desvio Padrão & & & 4,09 \\
\hline
\end{tabular}

Para linfonodos bronquiais de fetos abortados de bovinos, a média das concentrações de DNA extraído pelo protocolo GT foi maior que aquelas obtidas pelos protocolos PK e Boom ( $p<0,001$, Tabela 24).

O gráfico 16 e a tabela 25 mostram que para linfonodos bronquiais de fetos abortados de bovinos existiu uma discreta correlação entre as concentrações de DNA $(\mu \mathrm{g} / \mathrm{mL})$ obtidas pelos três protocolos de extração. 


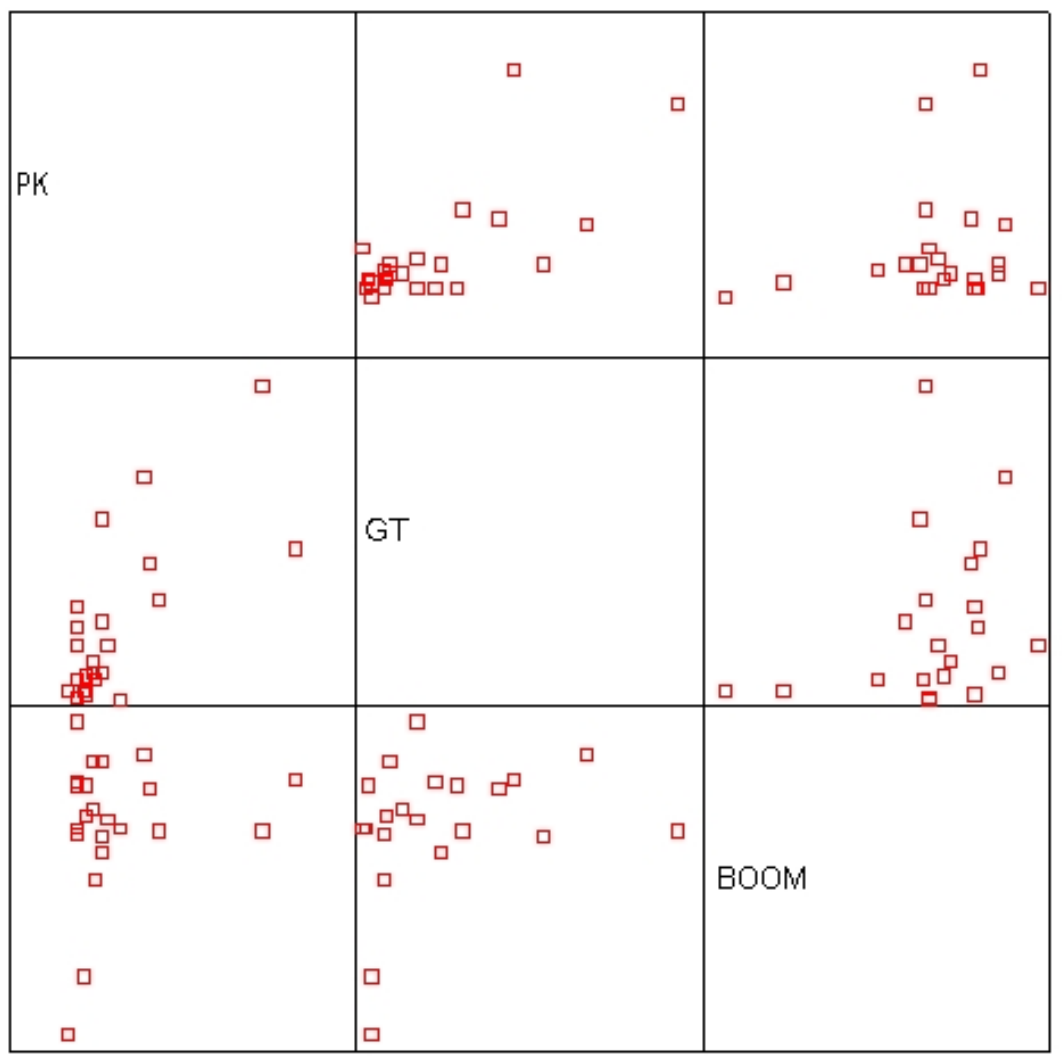

Gráfico 16- Correlação entre as concentrações de DNA de Brucella abortus ( $\mu \mathrm{g} / \mathrm{mL})$ obtidas por três protocolos de extração de amostras de linfonodo bronquial de feto abortado de bovino - São Paulo - 2008

Tabela 25 - Coeficiente de correlação de Pearson entre as concentrações de DNA de Brucella abortus $(\mu \mathrm{g} / \mathrm{mL})$ obtidas por os três protocolos de extração em de linfonodo bronquial de feto abortado de bovino - São Paulo - 2008

\begin{tabular}{c|cc}
\hline & GT & Boom \\
\hline PK & 0,712 & 0,186 \\
GT & & 0,247 \\
\hline
\end{tabular}


A comparação entre os resultados das PCR para os diferentes protocolos descritos nos itens 4.3.1., 4.3.2, 4.3.3., tomando como referência os resultados obtidos para isolamento das mesmas amostras de acordo com o item 4.1., estão apresentadas nas tabelas ilustradas abaixo (Tabelas 26, 27, 28, 29 e 30).

Tabela 26 - Resultados da PCR para deteç̧ão de Brucella abortus realizada com três protocolos de extração de DNA em amostras de pulmão de feto abortado de bovino, segundo resultados da bacteriologia clássica - São Paulo - 2008

\begin{tabular}{c|cc|c|c|c|c|c|c|c} 
& \multicolumn{9}{c|}{ Pulmão } \\
\cline { 2 - 11 } & \multicolumn{3}{c}{ PK } & \multicolumn{3}{c|}{ GT } & \multicolumn{3}{c}{ BOOM } \\
\cline { 2 - 11 } & Isolado & Não Isolado & Total & Isolado & Não Isolado & Total & Isolado & Não Isolado & Total \\
\hline PCR + & 17 & 4 & 21 & 14 & 1 & 15 & 16 & 10 & 26 \\
PCR - & 0 & 11 & 11 & 3 & 14 & 17 & 1 & 5 & 6 \\
Total & 17 & 15 & 32 & 17 & 15 & 32 & 17 & 15 & 32 \\
\hline
\end{tabular}

Sensibilidade diagnóstica do método $\mathrm{pK}=100 \%$

Especificidade diagnóstica do método $\mathrm{pK}=73 \%$

Sensibilidade diagnóstica do método GT $=82 \%$

Especificidade diagnóstica do método GT $=93 \%$

Sensibilidade diagnóstica do método Boom $=94 \%$

Especificidade diagnóstica do método Boom $=33 \%$

Tabela 27 - Resultados da PCR para detecção de Brucella abortus realizada com três protocolos de extração de DNA em amostras de baço de feto abortado de bovino, segundo resultados da bacteriologia clássica - São Paulo - 2008

\begin{tabular}{c|ccc|c|c|c|c|c|c} 
& \multicolumn{9}{c|}{ Baço } \\
\cline { 2 - 11 } & \multicolumn{3}{c}{ PK } & \multicolumn{3}{c|}{ GT } & \multicolumn{3}{c}{ BOOM } \\
\cline { 2 - 11 } & Isolado & Não Isolado & Total & Isolado & Não Isolado & Total & Isolado & Não Isolado & Total \\
\hline PCR + & 11 & 0 & 11 & 11 & 0 & 11 & 11 & 10 & 21 \\
PCR - & 0 & 15 & 15 & 0 & 15 & 15 & 0 & 5 & 5 \\
Total & 11 & 15 & 26 & 11 & 15 & 26 & 11 & 15 & 26 \\
\hline
\end{tabular}

Sensibilidade diagnóstica do método pK: $100 \%$

Especificidade diagnóstica do método pK: 100\%

Sensibilidade diagnóstica do método GT: 100\%

Especificidade diagnóstica do método GT: 100\%

Sensibilidade diagnóstica do método Boom: 100\%

Especificidade diagnóstica do método Boom: $33 \%$ 
Tabela 28 -. $\quad$ Resultados da PCR para detecção de Brucella abortus realizada com três protocolos de extração de DNA em amostras de fígado de feto abortado de bovino, segundo resultados da bacteriologia clássica - São Paulo - 2008

\begin{tabular}{c|ccc|c|c|c|c|c|c} 
& \multicolumn{9}{c|}{ Fígado } \\
\cline { 2 - 11 } & \multicolumn{3}{c}{ PK } & \multicolumn{3}{c|}{ GT } & \multicolumn{3}{c}{ BOOM } \\
\cline { 2 - 11 } & Isolado & Não Isolado & Total & Isolado & Não Isolado & Total & Isolado & Não Isolado & Total \\
\hline PCR + & 8 & 1 & 9 & 7 & 3 & 10 & 5 & 10 & 15 \\
PCR - & 0 & 14 & 14 & 1 & 12 & 13 & 3 & 5 & 8 \\
Total & 8 & 15 & 23 & 8 & 15 & 23 & 8 & 15 & 23 \\
\hline
\end{tabular}

Sensibilidade diagnóstica do método pK: 100\%

Especificidade diagnóstica do método pK: 93\%

Sensibilidade diagnóstica do método GT: $88 \%$

Especificidade diagnóstica do método GT: $80 \%$

Sensibilidade diagnóstica do método Boom: $63 \%$

Especificidade diagnóstica do método Boom: 33\%

Tabela 29 - $\quad$ Resultados da PCR para detecção de Brucella abortus realizada com três protocolos de extração de DNA em amostras de linfonodo bronquial de feto abortado de bovino, segundo resultados da bacteriologia clássica - São Paulo - 2008

\begin{tabular}{c|ccc|c|c|c|c|c|c} 
& \multicolumn{9}{c|}{ Linfonodo Bronquial } \\
\cline { 2 - 10 } & \multicolumn{3}{c}{ PK } & \multicolumn{3}{c|}{ GT } & \multicolumn{3}{c}{ BOOM } \\
\cline { 2 - 11 } & Isolado & Não Isolado & Total & Isolado & Não Isolado & Total & Isolado & Não Isolado & Total \\
\hline PCR + & 5 & 3 & 8 & 5 & 2 & 7 & 6 & 7 & 13 \\
PCR - & 2 & 12 & 14 & 2 & 13 & 15 & 1 & 8 & 9 \\
Total & 7 & 15 & 22 & 7 & 15 & 22 & 7 & 15 & 22 \\
\hline
\end{tabular}

Sensibilidade diagnóstica do método pK: $71 \%$

Especificidade diagnóstica do método pK: $80 \%$

Sensibilidade diagnóstica do método GT: $71 \%$

Especificidade diagnóstica do método GT: $87 \%$

Sensibilidade diagnóstica do método Boom: $86 \%$

Especificidade diagnóstica do método Boom: 53\% 
Tabela 30 - Resultados consolidados por órgãos de feto abortado de bovino para detecção de Brucella abortus pela PCR realizada com três protocolos de extração de DNA, segundo resultados da bacteriologia clássica - São Paulo - 2008

\begin{tabular}{|c|c|c|c|}
\hline & $\begin{array}{c}\text { PK } \\
\text { Isolamento positivo }\end{array}$ & $\begin{array}{c}\text { GT } \\
\text { Isolamento positivo }\end{array}$ & $\begin{array}{c}\text { BOOM } \\
\text { Isolamento positivo }\end{array}$ \\
\hline PCR + & 41 & 37 & 38 \\
\hline PCR - & 2 & 6 & 5 \\
\hline Total & 43 & 43 & 43 \\
\hline
\end{tabular}

Sensibilidade diagnóstica do método pK: $95 \%$

Sensibilidade diagnóstica do método GT: $86 \%$

Sensibilidade diagnóstica do método Boom: $88 \%$

5.2.2 Admitindo como gold standard a infecção experimental

Os resultados das PCR para os diferentes protocolos de extração de DNA, admitindo que todos os fetos abortados estavam infectados com B. abortus estão apresentados nas tabelas $31,32,33,34$ e 35 .

Tabela 31 - $\quad$ Resultados da PCR para detecção de Brucella abortus realizada com três protocolos de extração de DNA em amostras de pulmão de feto abortado de bovino experimentalmente infectado com a estirpe 2308 - São Paulo - 2008

\begin{tabular}{ccc}
\hline \multicolumn{3}{c}{ Pulmão } \\
\hline $\begin{array}{c}\text { PK } \\
\text { Infectados } \\
\text { experimentalmente }\end{array}$ & $\begin{array}{c}\text { GT } \\
\text { Infectados } \\
\text { experimentalmente }\end{array}$ & $\begin{array}{c}\text { BOOM } \\
\text { Infectados } \\
\text { experimentalmente }\end{array}$ \\
\hline 21 & 16 & 26 \\
11 & 16 & 6 \\
32 & 32 & 32 \\
\hline
\end{tabular}

Sensibilidade diagnóstica do método pK: $66 \%$

Sensibilidade diagnóstica do método GT: $50 \%$

Sensibilidade diagnóstica do método Boom: $81 \%$ 
Tabela 32 - Resultados da PCR para detecção de Brucella abortus realizada com três protocolos de extração de DNA em amostras de baço de feto abortado de bovino experimentalmente infectado com a estirpe 2308 - São Paulo - 2008

\begin{tabular}{c|c|c|c|}
\cline { 2 - 4 } \multicolumn{2}{c|}{} & \multicolumn{3}{c|}{\begin{tabular}{c} 
Baço \\
Infectados \\
\cline { 2 - 4 }
\end{tabular}} & $\begin{array}{c}\text { GT } \\
\text { Infectados } \\
\text { experimentalmente }\end{array}$ & $\begin{array}{c}\text { BOOM } \\
\text { Infectados } \\
\text { experimentalmente }\end{array}$ \\
\hline PCR + & 11 & 11 & 21 \\
PCR - & 15 & 15 & 5 \\
Total & 26 & 26 & 26 \\
\hline
\end{tabular}

Sensibilidade diagnóstica do método pK: $42 \%$

Sensibilidade diagnóstica do método GT: $42 \%$

Sensibilidade diagnóstica do método Boom: $81 \%$

Tabela 33 - $\quad$ Resultados da PCR para detecção de Brucella abortus realizada com três protocolos de extração de DNA em amostras de fígado de feto abortado de bovino experimentalmente infectado com a estirpe 2308 - São Paulo - 2008

\begin{tabular}{c|c|c|c}
\cline { 2 - 4 } & \multicolumn{3}{c}{ Fígado } \\
\cline { 2 - 4 } & $\begin{array}{c}\text { PK } \\
\text { Infectados } \\
\text { experimentalmente }\end{array}$ & $\begin{array}{c}\text { GT } \\
\text { Infectados } \\
\text { experimentalmente }\end{array}$ & $\begin{array}{c}\text { BOOM } \\
\text { Infectados } \\
\text { experimentalmente }\end{array}$ \\
\hline PCR + & 9 & 10 & 15 \\
PCR - & 14 & 13 & 8 \\
Total & 23 & 23 & 23 \\
\hline
\end{tabular}

Sensibilidade diagnóstica do método pK: $39 \%$

Sensibilidade diagnóstica do método GT: $43 \%$

Sensibilidade diagnóstica do método Boom: $65 \%$ 
Tabela 34 - Resultados da PCR para detecção de Brucella abortus realizada com três protocolos de extração de DNA em amostras de linfonodo bronquial de feto abortado de bovino experimentalmente infectado com a estirpe 2308 - São Paulo - 2008

\begin{tabular}{c|c|c}
\hline \multicolumn{3}{c}{ Linfonodo } \\
$\begin{array}{c}\text { Infectados } \\
\text { experimentalmente }\end{array}$ & $\begin{array}{c}\text { GT } \\
\text { Infectados } \\
\text { experimentalmente }\end{array}$ & $\begin{array}{c}\text { BOOM } \\
\text { Infectados } \\
\text { experimentalmente }\end{array}$ \\
\hline 8 & 7 & 13 \\
14 & 15 & 9 \\
22 & 22 & 22 \\
\hline
\end{tabular}

Sensibilidade diagnóstica do método pK: $36 \%$

Sensibilidade diagnóstica do método GT: $32 \%$

Sensibilidade diagnóstica do método Boom: 59\%

Tabela 35 - Resultados consolidados por órgãos de feto abortado de bovino experimentalmente infectado com a estirpe 2308 para detecção de Brucella abortus pela PCR realizada com três protocolos de extração de DNA - São Paulo - 2008

\begin{tabular}{|c|c|c}
\hline $\begin{array}{c}\text { PK } \\
\text { Infectados } \\
\text { experimentalmente }\end{array}$ & $\begin{array}{c}\text { GT } \\
\text { Infectados } \\
\text { experimentalmente }\end{array}$ & $\begin{array}{c}\text { BOOM } \\
\text { Infectados } \\
\text { experimentalmente }\end{array}$ \\
\hline 49 & 44 & 75 \\
54 & 59 & 28 \\
103 & 103 & 103 \\
\hline
\end{tabular}

Sensibilidade diagnóstica do método pK: $47 \%$

Sensibilidade diagnóstica do método GT: $43 \%$

Sensibilidade diagnóstica do método Boom: $73 \%$ 
As figuras de 1 a 3 mostram os resultados da amplificação da PCR para os diferentes protocolos de extração de DNA testados.

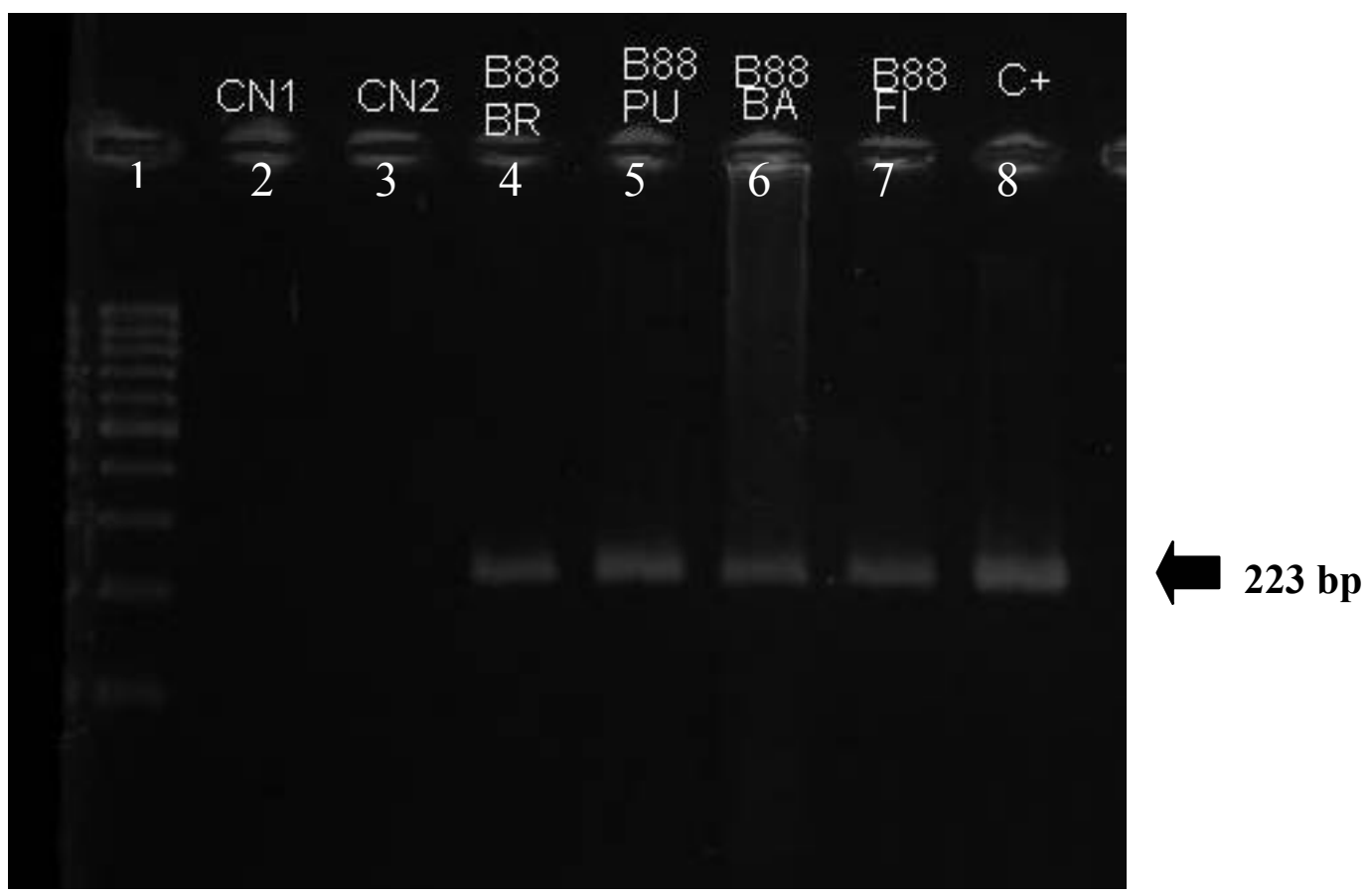

(1) padrão de peso molecular, $100 \mathrm{bp}$; (2) controle negativo; (3) controle negativo; (4) amostra de linfonodo bronquial; (5) amostra de pulmão; (6) amostra de baço; (7) amostra de fígado; (8) controle positivo.

Figura 1- Gel de agarose mostrando resultado de PCR em amostras de linfonodo bronquial, pulmão, baço e fígado de feto abortado de vacas experimentalmente desafiadas com Brucella abortus 2308, utilizando extração enzimática do DNA por Proteinase K - São Paulo - 2008 


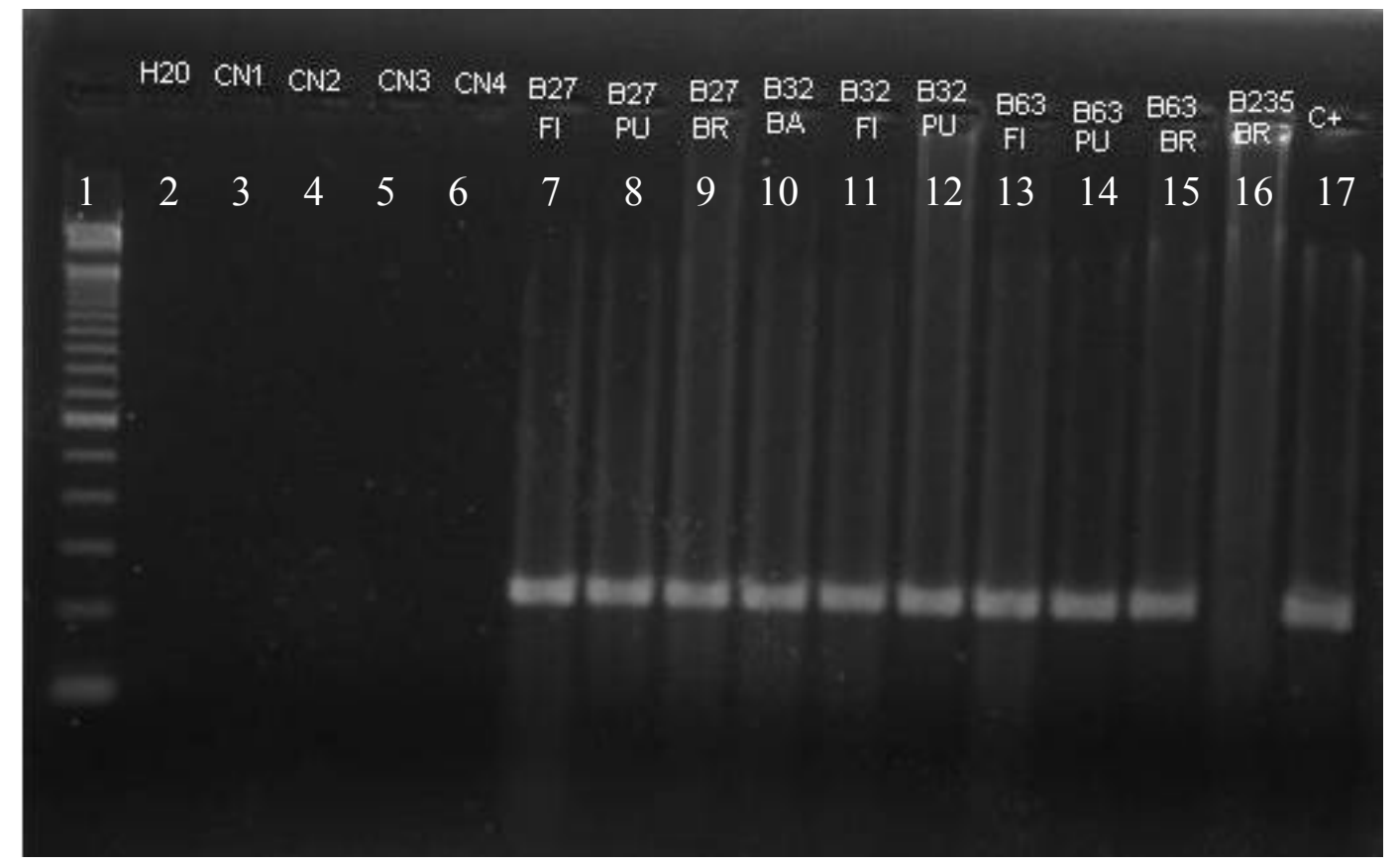

223 bp

(1) padrão de peso molecular, $100 \mathrm{bp}$; (2) água; (3) controle negativo; (4) controle negativo; (5) controle negativo; (6) controle negativo; (7) amostra de fígado; (8) amostra de pulmão; (9) amostra de linfonodo bronquial; (10) amostra de baço; (11) amostra de fígado; (12) amostra de pulmão; (13) amostra de fígado; (14) amostra de pulmão, (15) amostra de linfonodo bronquial, (16) amostra de linfonodo bronquial, (17) controle positivo.

Figura 2 - Gel de agarose mostrando resultado de PCR em amostras de linfonodo bronquial, pulmão, baço e fígado de feto abortado de vacas experimentalmente desafiadas com Brucella abortus 2308, utilizando extração do DNA pelo Isotiocianato de Guanidina (GT) - São Paulo - 2008 


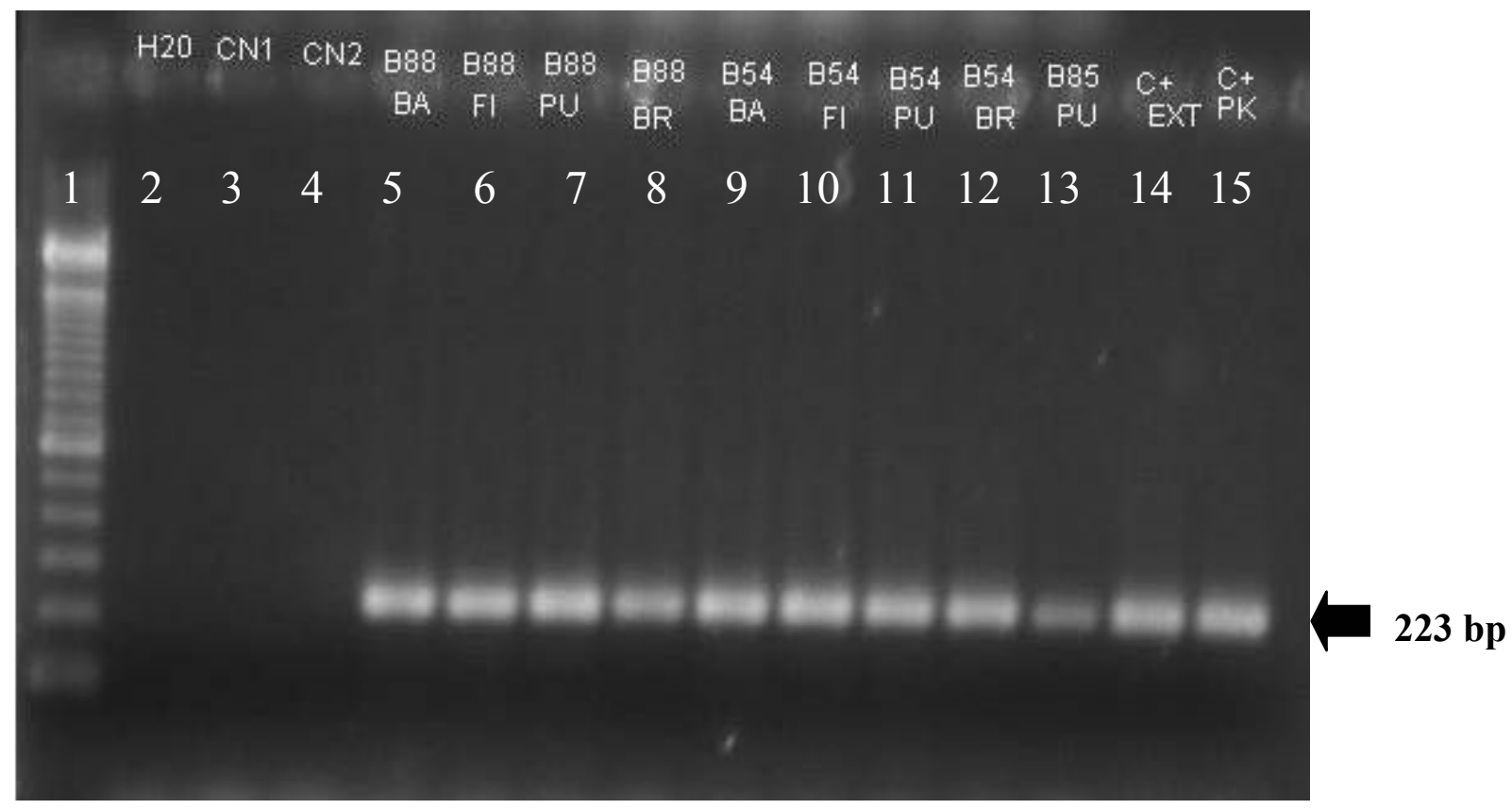

(1) padrão de peso molecular, $100 \mathrm{bp}$; (2) água; (3) controle negativo; (4) controle negativo; (5) amostra de baço; (6) amostra de fígado; (7) amostra de pulmão; (8) amostra de linfonodo bronquial; (9) amostra de baço; (10) amostra de fígado; (11) amostra de pulmão; (12) amostra de linfonodo bronquial; (13) amostra de pulmão; (14) controle positivo da extração; (15) controle positivo.

Figura 3 - $\quad$ Gel de agarose mostrando resultado de PCR em amostras de linfonodo bronquial, pulmão, baço e fígado de feto abortado de vacas experimentalmente desafiadas com Brucella abortus 2308, utilizando extração do DNA pelo Boom - São Paulo - 2008 


\section{DISCUSSÃO}

\subsection{ENSAIOS COM CULTURAS PURAS}

O melhor limiar de detecção foi verificado para o protocolo $\mathrm{PK}\left(10^{-2}\right.$ bactérias $\left./ \mathrm{mL}\right)$, seguido do Boom ( $10^{1}$ bactérias $\left./ \mathrm{mL}\right)$ e GT $\left(10^{5}\right.$ bactérias $\left./ \mathrm{mL}\right)$ (Tabela 1$)$.

Esses resultados indicam que o protocolo PK detectou uma fração de 1/100 de bactéria, o que é incoerente. Isso provavelmente foi conseqüência da baixa precisão da quantificação pela escala de McFarland. De fato, as contagens de UFC feitas a partir das suspensões examinadas, mostraram um número sempre superior de UFC àquela prevista pela escala. Além disso, é razoável supor que existam UFC produzidas por mais de um bacilo. Em resumo, a escala de McFarland e as contagens de UFC sub-quantificaram o número de bacilos em suspensão.

A tabela 4 mostra que nenhum protocolo alcançou valores entre 1,8 e 2,0 para as médias de razão de absorbância em 260 e 280 nm, preconizado por Sambrook e Russell (2001) para avaliar a pureza do ácido nucléico. Segundo esses autores, valores inferiores a 1,8 podem significar contaminação com proteína ou fenol, além de não permitirem a quantificação precisa do ácido nucléico. Apesar disso, essa quantificação foi realizada, e os resultados constam da Tabela 2 , onde se verifica que o protocolo de Boom teve concentrações menores de DNA que o PK $(p<0,05)$ e que o GT $(p<0,01)$.

Os gráficos de 1 a 8 e as tabelas 3 e 5 mostram que, para os três protocolos de extração, não existe associação entre a concentração de DNA ou o grau de pureza do DNA com a quantidade de bactérias presente nas suspensões. Também não existe associação entre os protocolos de extração de DNA no referente às concentrações de DNA ou os graus de pureza do DNA obtidos.

Assim, existem duas possibilidades as serem consideradas: 1) a espectrofotometria, como recomendada por Sambrook e Russell (2001), não é a metodologia ideal para mensuração da concentração de DNA, 2) existe pouca reprodutibilidade nos resultados dos protocolos de extração de DNA. 


\subsection{ADMITINDO COMO GOLD STANDARD O ISOLAMENTO}

O baço foi o melhor órgão para detecção de $B$. abortus pela PCR em homogeneizados de órgãos de fetos abortados, seguido do pulmão, do fígado e do lifonodo bronquial, (Tabelas 26 a 29). Foi apenas no baço que a sensibilidade diagnóstica da PCR foi de $100 \%$ para qualquer dos protocolos de extração de DNA ensaiados (Tabela 27).

Para os linfonodos, a melhor sensibilidade diagnóstica foi observada para o protocolo de Boom (86\%, Tabela 29). Ribeiro (2006) estudou três protocolos de extração para detecção de Mycobacterium bovis em homogeneizados de órgãos, sobretudo de linfonodos e verificou que o melhor deles foi o de Boom.

Os resultados consolidados por órgãos mostram que o protocolo de PK foi o mais sensível (Tabela 30). Cortez et al. (2001), observaram que tanto o protocolo da PK quanto o da lise pela fervura foram eficazes para a extração de DNA de $B$. abortus.

A experiência amadurecida com a PCR nos vários laboratórios do Departamento de Medicina Preventiva e Saúde Animal da FMVZ, USP indicava uma expectativa de melhor performance do protocolo de Boom. Entretanto, os resultados frustraram essa expectativa em favor do protocolo de PK (Tab. 30). Esse fato pode ter sido decorrente da permanência de resquícios da suspensão carreadora (Diatomaceous earth) na etapa final da extração, fazendo com que o DNA ficasse aderido a ela, não conseguindo eluir-se.

A menor sensibilidade do protocolo GT pode ter sido resultado da presença de uma maior quantidade de fatores de inibição da amplificação do ácido nucléico, como proteínas séricas, debris celulares somáticos, polissacárides e outros componentes dos fluídos corpóreos (WILSON, 1997), pois para esse método não foi realizada a prélavagem das amostras, procedimento que antecedeu a extração no protocolo de PK e foi realizado como etapa intermediária no de Boom.

Nas 60 amostras (15 baços, 15 fígados, 15 linfonodos bronquiais e 15 pulmões) das quais não foi possível isolar B. abortus (gold standard negativo), a PCR resultou positiva em 8 amostras para o protocolo de extração PK (4 pulmões, 1 fígado e 3 linfonodos), em 6 amostras para o protocolo de extração GT (1 pulmão, 3 fígados e 2 linfonodos) e em 37 amostras (10 pulmões, 10 baços, 10 fígados e 7 linfonodos) para o protocolo de extração do Boom (Tabelas 26 a 29). Nas amostras onde o isolamento foi negativo, a proporção de PCR positivos verificada para o protocolo de extração Boom $(37 / 60)$ foi superior àquelas verificados para o PK $(8 / 60, p=0,0054)$ e o GT $(6 / 60$, 
$p=0,0011)$. Como todos os animais utilizados no estudo foram gerados por vacas experimentalmente infectadas, é razoável supor que esses resultados da PCR não são falsos positivos, embora o isolamento tenha resultado negativo. Em estudos envolvendo detecção de B. abortus em amostras de abortos bovinos, Cortez et al. (2001) detectaram 4 amostras positivas para PCR em 54 negativas para cultivo e Fekete et al. (1990) obtiveram 2 amostras positivas em 52 negativas pelo cultivo microbiológico. A especificidade da PCR não está associada ao protocolo de extração, mas aos primers utilizados. No presente experimento foram utilizados os primers B4 e B5 descritos por Baily et al. (1992) para detecção de Brucella abortus e Brucella mellitensis. Esses autores verificaram as seqüências dos primers nos bancos de dados para seqüências de nucleotídeos Genbank e EMBL (European Molecular Biology Laboratory) e não identificaram nenhuma significante homologia de seqüências de outras bactérias com estas da Brucella. Estes primers foram utilizados com sucesso para o diagnóstico de infecção por brucela por vários autores (Matar et al., 1996; ZERVA et al., 2001; CORTEZ et al., 2001; RICHTZENHAIN et al., 2002), que jamais relataram reações falso positivas. Problema de inespecificidade foi relatado apenas frente à infecção humana por Ochrobactrum anthropi (CIESLAK et al., 1992; GRANSDEN; EYKYN, 1992; MANFREDI, 1999; CASANAS et al., 2001).

No estudo dos órgãos, os resultados observados para as mensurações das concentrações de DNA e para as razões de absorbância registradas com leituras em diferentes comprimentos de onda $(260 \mathrm{~nm} / 280 \mathrm{~nm})$ foram organizados nas tabelas de 7 a 10,12 a 15,17 a 20,22 a 25 e nos gráficos de 9 a 16. A interpretação desses resultados é exatamente a mesma já feita para as análises com as culturas puras. As duas únicas exceções foram verificadas para os resultados das concentrações de DNA obtidas a partir do baço e do linfonodo bronquial, onde houve correlação discreta entre os resultados dos protocolos de extração de PK e GT (Gráficos 12 e 16 e Tabelas.15 e 25).

Assim, pode-se considerar que dentre os órgãos estudados, uma maior probabilidade de detecção de $B$. abortus, foi verificada no baço. Entretanto, vale ressaltar que uma maior sensibilidade foi alcançada pela utilização da PCR e do isolamento em paralelo. 


\subsection{ADMITINDO COMO GOLD STANDARD A INFECÇÃO EXPERIMENTAL}

Os resultados demonstrados nas tabelas $31,32,33,34$ e 35 apontam o Boom como o melhor protocolo de extração do DNA quando se considera que o gold standard é a infecção experimental. A sensibilidade diagnóstica neste caso, também apontou o baço como órgão onde é maior a probabilidade de detecção de Brucella abortus, dentre os órgãos estudados. 


\section{CONCLUSÕES}

1- O protocolo de extração influencia a sensibilidade e a especificidade diagnósticas da PCR aplicada em homogeneizado de órgãos para detecção de Brucella abortus.

2- O baço apresentou maior probabilidade de detecção de Brucella abortus pela PCR do que o pulmão, o fígado e o linfonodo bronquial.

3- A melhor estratégia para detectar Brucella abortus em tecidos de fetos abortados é a utilização da PCR e do isolamento em paralelo. 


\section{REFERÊNCIAS}

ACHA, P. N.; SZYFRES, B. Zoonosis y enfermedades transmisibles comunes al hombre y a los animales. 3. ed. Washington: O.P.S., 2001. 28-55 p.

ALTON, G. G.; JONES M. L.; PIETZ D. E. Las tecnicas de laboratorio em la brucelosis. Ginebra: OMS, 1975. p. 79-126.

BAILY, G. G.; KRAHN, J. B.; DRASAR, B. S.; SOKER, N. G. Detection of Brucella melitensis and Brucella abortus by DNA amplification. Journal of Tropical Medicine and Hygiene, v. 95, p. 271-275, 1992.

BOOM, R.; SOL, C. J. A.; SALIMANS, M. M. M.; JANSEN, C. L.; WERTHEIM-VAN DILLEN, P. M.E.; VAN DER NOORDAA, J. Rapid and simple method for purification of nucleic acids. Journal of Clinical Microbiology, v. 28, n. 3, p. 495-503, 1990.

BRASIL, Ministério da Agricultura, Pecuária e Abastecimento (MAPA). Planos e Programas. Programas. Área Animal. Programa Nacional de Controle e Erradicação da Brucelose e da Tuberculose (PNCEBT). Instrução Normativa do Serviço Nacional Animal número 6, de oito de janeiro de 2004. Regulamento PNCEBT. Disponível em: $<$ http://www.agricultura.gov.br>. Acesso em: 25 de março de 2008.

BRICKER, B. J. PCR as a diagnostic tool for brucellosis. Veterinary Microbiology, v. 90, p. 435-446, 2002.

BRICKER, B. J.; EWALT, D. R.; HALLING, S. M. Brucella "HOOF- Prints": strain typing by multi-locus analysis of variable number tandem repeats (VNTRs). BMC Microbiology, $v$. 3, p. 15, 2003.

CARTER, G. R.; CHENGAPPA, M. M. Essentials of veterinary bacteriology and mycology. Filadelfia: Lea \& Febiger, 1991. p. 196-200.

CASANAS, M. C.; QUEIPO-ORTUNO, M. I.; RODRIGUEZ-TORRES, A.; ORDUNA, A.; COLMENERO, J. D.; MORATA, P. Specificity of a polymerase chain reaction assay of a target sequence on the 31 Kilodalton Brucella antigen DNA used to diagnose human brucellosis. European Journal Clinical Microbiology Infectious Diseases, v. 20, n. 2, p. 127-131, 2001.

ÇETINKAIA, B.; ONGOR, H.; MUZ, A.; ERTAS, H. B.; KALENDER, H.; ERDOGAN, H. M. Detection of Brucella species DNA in the Stomach Content of Aborted Sheep Fetuses by PCR. The Veterinary Record, v. 144, p. 239-240, 1999.

CIESLAK, T. J.; ROBB, M. L.; DRABICK, C. J.; FISCHER, G. W. Catheter-associated sepsis caused by Ochrobactrum anthropi: report of a case and review of related nonfermentative bacteria. Clinical Infectious Diseases, v. 14, n. 4, p. 902-907, 1992.

CHOMKZYNSKI, P. A. Reagent for the single step simultaneous isolation of RNA, DNA and proteins from cells and tissue samples. Biotechniques, v. 15, p. 532-537, 1993. 
CHU, M. C.; WEYANT, R. S. Francisella and Brucella. In: MURRAY, P. R.; BARON, E. J.; JORGENSON, J. H.; PFALLER, M. A.; YOLKEN, R. H. Manual of Clinical Microbiology. 8. ed. Washington: ASM Press, 2003, p. 789-804.

CIPOLLA, A.; SALUSTIO, E.; BOSCHIROLI, L.; CAMPOS, E.; ODRIOZOLA, E.; CAMPERO, C. L.; SAMARTINO, L.; ROSSETTI, O.; GAGLIARDO,L. Caracterizacion bioquímica y molecular de cepas de Brucella abortus aisladas en Argentina. Instituto Nacional de Tecnologia Agropecuária: Estación Experimental Agropecuária Balcarce, 2004.

CLOECKAERT, A.; GRAYON, M.; GREPINET, O.; BOUMEDINE, K. S. Classification of Brucella strains isolated from marine mammals by infrequent restriction site-PCR and development of specific PCR identification tests. Microbes and Infection, v. 5, n. 7, p. 593-602, 2003.

CLOECKAERT, A.; VERGER, J. M.; GRAYON, M.; VIZCAÍNO, N. Molecular and immunological characterization of the major outer membrane proteins of Brucella. FEMS Microbiology Letters, v.145, p.1-8, 1996.

CORBEL, M. J. Brucellosis: an Overview. $1^{\text {st }}$ International Conference on Emerging Zoonoses Jerusalem, Isarel, v. 3, n. 2, 1997.

CORTEZ, A.; SCARCELLI, E.; SOARES, R. M.; HEINEMANN, M. B.; SAKAMOTO, S. M.; GENOVEZ, M. E.; FERREIRA, F.; RICHTZENHAIM, L. J. Detection of Brucella DNA from aborted bovine foetuses by polymerase chain reaction. Australian Veterinary Journal, v. 79 , n. 7 , p. $500-501,2001$

DA COSTA, M.; GUILLOU, J. P.; GARIN-BASTUJI, B.; THIÉBAUD, M.;DUBRAY, G. Specificity of six gene sequences for the detection of the genus Brucella by DNA amplification. Journal of Applied Bacteriology, v. 81, p. 267-275, 1996.

DAHOUK, S. A.; TOMASO, H.; NOCKLER K.; NEUBAUER H.; FRANGOULIDIS D. Laboratory based diagnosis of brucellosis- A review of the literature. Clinical Laboratory v. 49, p. 487-505, 2003.

DIEFFENBACH, C.W.; DRAGON, E.A.; DVEKSLER, G.S. Setting up a PCR laboratory. In: PCR primer: a laboratory manual. New York, Cold Spring, Harbor Laboratory Press, 1995. p. 7-16.

FEKETE, A.; BANTLE, J. A.; HALLING, S. M. DETECTION OF Brucella by polymerase chain reaction in bovine fetal and maternal tissues. Journal of Veterinay Investigation, $v$. 4, p. 79-83, 1992b.

FEKETE, A.; BANTLE, A. J.; HALLING, S. M. Preliminary development of diagnostic test for Brucella using polymerase chain reaction. Journal Applied Bacteriology, v. 69, p. 216-227, 1990a. 
GALLIEN, P.;DORN, C.; ALBAN, G.; STAAK, C.; PROTZ, D. Detection of Brucella species in organs of naturally infected cattle by polymerase chain reaction. Veterinary Record, $p$ 512-514, 1998.

GARCÍA-CARRILLO, C. La brucellosis de los animales en América y su relacíon com la infeccíon humana. Office International des Épizooties, Paris: 1987. 43-70 p.

GRANSDEN, W. R.; EYKYN, S. J. Seven cases of bacteremia due to Ochrobactrum anthropi. Clinical Infectious Diseases, v. 15, n. 6, p. 1068-1069, 1992.

GULER, L.; GUNDUZ, K.; OK, U. Comparison of polymerase chain reaction and bacteriological culture for the diagnosis of sheep brucellosis using aborted fetus samples. Veterinary Microbiology, v. 93, p. 53-61, 2003.

IKRAM, M.; HILL, E. Microbiology for veterinary technicians, 1. ed. Goleta: American Veterinary Publications, 1991.

LAGE, A. P.; ROXO, E.; MÜLLER, E.; POESTER, F.; CAVALLÉRO, J. C. M.; FERREIRA NETO, J. S.; MOTA, P. M. P. C.; GONÇALVES, V. S. P. Programa nacional de controle e erradicação da brucelose e da tuberculose animal (PNCEBT). 1. ed. Brasília: Ministério da Agricultura, Pecuária e Abastecimento, 2006, 188 p. (Manual Técnico).

LEAL-KLEVEZAS, D. S.; MARTINEZ-VAZQUEZ, I. O.; GARCÍA-CANTÚ, J.; LOPEZMERINO, A.; MARTINEZ-SORIANO, J. P. Use of polimerase chain reaction to detect Brucella abortus biovar 1 in infected goats. Veterinary Microbiology, v. 75, p. 91-97, 2000.

LEAL-KLEVEZAS, D.S.; MARTINEZ-VAZQUEZ, I.O.; LOPEZ-MERINO, L.; MARTINEZSORIANO, J.P. Single-stpe PCR for detection of Brucella spp. From blood and milk of infected animals. Journal Clinical Microbiology v. 12, p. 3087-3090, 1995a.

MANFREDI, R.; NANETTI, A.; FERRI, M.; CHIODO, F. Nosocomial sepsis due to Ochrobactrum anthropi in HIV positive patients: two case reports. Le Infezioni in Medicina, v. 7, n. 2, p. 119-124, 1999.

MARIANELLI, C.; GRAZIANI, C.; SANTANGELO, C.; XIBILIA, M. T.; AMATO, R.; NERI, D.; CUCCIA, M.; RINNONE, S.; DI MARCO, V.; CIUCHINI, F. Molecular Epidemiological and Antibiotic Susceptibility Characterization of Brucella Isolates from Humans in Sicily, Italy. Journal of Clinical Microbiology, v. 45, n. 9, p. 2923-2928, 2007.

MATAR, G. M.; KHNEISSER, I. A.; ABDELNOOR, A. M. Rapid laboratory confirmation of human brucellosis by PCR analysis of a target sequence on the 31 kilodalton Brucella antigen DNA. Journal of Veterinary Microbiology, v. 34, n. 2, p. 477-478, 1996.

MAURIN, M. La Brucellose à l'aube du $21^{\circ}$ siècle. Médecine et Maladies Infectieuses, v. 35, p. 6-16, 2005. 
MEGID, J.; ALBERT, D.; FAGLIARI, J. J.; PAES, A. C.; LISTONI, F. P.; PINTO, M. R. A.; RIBEIRO, M. G.; THIÉBAUD, M.; UENO, T.; GARIN-BASTUJI, B. Isolation of Brucella abortus from cattle and water buffalo in Brasil. Veterinary Record, v. 156, p.147-148, 2005.

MELLO, M. T. Animal Brucellosis in Brazil. In: 1950, Washington. Proceedings of the INTER-AMERICAN CONGRESS ON BRUCELLOSIS. p. 56-89.

METCALF, H. E.; LUCHSINGER, D. W.; RAY, W. C. Brucellosis. In: BERAN, G. W.; STEELE, J.H. (Ed.). Handbook series in Zoonoses. Section A: bacterial, rickettsial, chlamydial, and mycotic. 2. ed. Boca Raton: CRC Press, 1994. p. 9-39.

OIE. Organização Internacional de Epizootia. Bovine Brucellosis. Article 2.3.1.

Terrestrial Animal Health code 2006, part 2, chapter 2.3.1. Disponível em:<http://www.oie.int>. Acesso em: 28 de março de 2008.

PADILLA, C. R.; MONTOYA, Y. P.; CARRILLO, C. P. Estandarización de una prueba de PCR para la detección de Brucella sp. Revista Peruana de Medicina Experimental y Salud Pública, v. 20, n. 2, p.102-104, 2003

PAULIN, L. M.; FERREIRA NETO, J. S. O combate à brucelose bovina. 1. ed. Jaboticabal: FUNEP, 2003.

PEARCE, J. H.; WILLIANS, A. E.; HARRIS-SMITH, P. W.; FITZGEORGE, R. B.; SMITH $\mathrm{H}$. The chemical basis of the virulence of Brucella abortus. II. Erytritol, a constituent of bovine foetal fluids which stimulates the growth of Brucella abortus in bovine phagocytes. British Journal of Experimental Pathology, v. 43, p. 31-37, 1961.

POESTER, F. P.; GONÇALVES, V. S. P.; LAGE, A. P. Brucellosis in Brazil. Veterinary Microbiology, v. 90, p. 55-62, 2002.

POESTER, F. P.; GONÇALVES, V. S.; PAIXAO, T. A.; SANTOS, R. L.; OLSEN, S. C.; SCHURIG, G. G.; LAGE, A. P. Efficacy of strain RB51 vaccine in heifers against experimental brucellosis. Vaccine v. 24, n. 25, p.5327-5534, 2006.

RAJASHEKARA, G.; GLASNER, J. D.; GLOVER, D. A.; SPLITTER, G. A. Comparative Whole-Genome Hybridization Reveals Genomic Islands in Brucella Species. Journal of Bacteriology, v. 186, n. 15, p. 5040-5051, 2004.

RIBEIRO, D.C. Comparação de protocolos de extração de DNA para detecção de Mycobacterium bovis através da PCR em homogeneizado de órgãos. 2006. $55 \mathrm{f}$. Dissertação (Mestrado em Medicina Veterinária Preventiva e Saúde Animal) - Faculdade de Medicina Veterinária e Zootecnia, Universidade de São Paulo, São Paulo, 2006.

RICHTZENHAIN, L. J.; CORTEZ, A.; HEINEMANN, M. B.; SOARES, R. M.; SAKAMOTO, S. M.; VASCONCELLOS, S. A.; HIGA, Z. M. M.; SCARCELLI, E.; GENOVEZ, M. E. A multiplex PCR for the detection of Brucella spp. and Leptospira spp. DNA from aborted bovine fetuses. Veterinary Microbiology, v. 87, p. 139-147, 2002. 
RIEMANN, H. P.; CLIVER, D. O. Foodborne Infections and Intoxications. 3. ed. California: Elsevier Academic Press, 2006, p. 346-347.

ROMERO, C.; GAMAZO, C.; PARDO, M.; LÓPEZ-GONI, I. Specific detection of Brucella DNA by PCR. Journal of Clinical Microbiology, v. 33, n. 3, p. 615-617, 1995.

SALDARRIAGA, O. A; OSSA, J. E.; RUGELES, M. T. Respuesta inmune y estratégias de evasión durante la infección con Brucella spp. Revista Colombiana de Ciências

Pecuárias, v. 15, n. 2, p. 180-187, 2002.

SAMBROOK, J.; RUSSELL, D. W. Molecular Cloning: a laboratory manual. 3. ed. New York: Cold Spring Harbor, 2001.

SEÓNADH, O. L.; MICHAEL, S.; TORRES, S. Brucella abortus detection by PCR assay in blood, milk and lymph tissue of serologically positive cows. Research in Veterinary Science, v. 81, p. 170-176, 2006.

THOEN, C. O.; ENRIGHT, F. Brucella. In: GYLES, C. L; PRESCOTT, J. F.; SONGER, J. G.; THOEN, C. O. Pathogenesis of bacterial Infection in Animals. 2. ed. Ames: lowa State University Press, 1988, p. 160-169.

TORTORA, G. J; FUNKE, B. R.; CASE, C. L. Microbiologia. 6. ed. Porto Alegre: Artmed, 2000. p. 607-609.

VIEIRA, N. R. Desenvolvimento de uma Reação em Cadeia de Polimerase (PCR) para detecção de Brucella spp., em amostras de sangue de cães naturalmente infectados. 2004. 92 f. Dissertação (Mestrado em Medicina Veterinária Preventiva e Saúde Animal) - Faculdade de Medicina Veterinária e Zootecnia, Universidade de São Paulo, São Paulo, 2004.

ZERVA, L.; BOURANTAS, K.; MITKA, S.; KANSOUZIDOU, A.; LEGAKIS, N. J. Serum is the preferred clinical specimen for diagnosis of human brucellosis by PCR. Journal of Clinical Microbiology, v. 39, n. 4, p. 1661-1664, 2001.

WHATMORE, A. M.; SHANKSTER, S.J.; PERRETT, L. L.; MURPHY, T. J.; BREW, S. D.; THIRLWALL, R. E; CUTLER, S. J.; MACMILLAN, A. P. Identification and Characterization of Variable-Number, Tandem-Repeat Markers for Typing of Brucella spp. Journal of Clinical Microbiology, v. 44, n. 6, p. 1982-1993, 2006.

WILSON, I.G. Inhibition and facilitation of nucleic acid amplification. Applied and Enviromental Microbiology, p. 3741-3751, 1997. 